\title{
Universidad de los Andes
}

\author{
Economics Faculty
}

I know, therefore I am healthier? The role of education in health-related behaviors

Adviser: Mauricio Santa María Salamanca

Daniela Escobar López

(code: 201326368) 


\title{
I know, therefore I am healthier? The role of education in health-related behaviors
}

\author{
Daniela Escobar López
}

\begin{abstract}
:
To know how better economic conditions impact health-related choices is critical when formulating public policies that aim at improving the population's health, both in terms of outcomes and habits. Through the use of two national surveys, we investigate the effect of one additional year of schooling on the amount of time of physical activity done per week, and on the servings consumed of fruits and vegetables per day, in urban Colombia. Furthermore, intending to find causal links, we exploited as a source of exogenous variation a change in regulation concerning basic education implemented in the 1970s, in a 2SLS framework. Our results suggest that higher levels of education have a positive impact on food consumption habits, and on the undertaking of physical activity, especially when it is done for leisure. Conversely, transportmotivated physical activity is unaffected by higher educational attainment, which points to the presence of protective factors in low SES individuals. For the consumption part, we find that access is a necessary condition for individuals to make healthy diet choices."
\end{abstract}

Key words: Health, behavior, education, Colombia, urban, instrumental variables

JEL codes: C26, I12, I21, I26

\footnotetext{
* I wish to thank my adviser, Mauricio Santa María (EConcept AEI), for his invaluable guidance and mentorship throughout the making of this investigation. Likewise, I would like to thank David Bardey (Universidad de los Andes) and Diego Iván Lucumí (Universidad de los Andes) for their feedback and suggestions, and Rachid Laajaj (Universidad de los Andes) for his comments during the initial stages of the research. All mistakes in this document are only my own. For comments, write to d.escobar12@uniandes.edu.co.
} 


\title{
¿Sé, entonces soy más saludable? El rol de la educación en los comportamientos saludables.
}

\author{
Daniela Escobar López
}

\begin{abstract}
Resumen:
Conocer cómo un mayor nivel de educación afecta las decisiones de los individuos relacionadas con su salud es fundamental para formular políticas públicas que apuntan a mejorar la salud de la población, en términos tanto de resultados como de hábitos. A través del uso de dos encuestas nacionales, se investiga el efecto de un mayor nivel de educación sobre la cantidad de actividad física hecha por semana y el número de porciones de frutas y verduras consumidas al día, en las zonas urbanas de Colombia. Además, explotamos como fuente de variación exógena un cambio de regulación sobre la educación primaria implementado en la década de 1970, en un marco de Mínimos Cuadrados en Dos Etapas. Los resultados indican que mayores niveles educativos tienen un impacto positivo en el consumo de frutas y verduras y en la actividad física, especialmente cuando se hace por ocio. En cambio, el ejercicio que se hace por motivos de transporte no se ve afectado por el nivel educativo, lo que indica la presencia de factores protectores en individuos de menor estatus socioeconómico. Para la parte de consumo, se encuentra que el acceso es una condición necesaria para la toma de decisiones saludables. ${ }^{\dagger}$
\end{abstract}

Palabras clave: Salud, comportamiento, educación, Colombia, urbano, variables instrumentales Clasificación JEL: C26, I12, I21, I26

\footnotetext{
$\dagger$ Deseo agradecer a mi asesor Mauricio Santa María (EConcept AEI), por su invaluable guía y acompañamiento durante esta investigación. Asimismo, deseo agradecer a David Bardey (Universidad de los Andes) y Diego Iván Lucumí (Universidad de los Andes), por sus comentarios y sugerencias, y a Rachid Laajaj (Universidad de los Andes) por su retroalimentación en las etapas iniciales de la investigación. Todos los errores en este documento son solo míos. Para comentarios, dirigirse a d.escobar12@uniandes.edu.co.
} 


\section{Introduction}

Why do some people get sick more frequently than others? Why do some people eat healthier, or work out more or do not smoke? Is it possible that these and other differences in health-related variables are associated with the Socioeconomic Status (SES)? The answers to these questions are key to deliver better public health diagnoses and to be able to formulate policies to improve the health status of a particular population. Even if the health outcomes deemed as relevant have changed, evolving with the development of new technologies, it has been consistently observed that disparities in morbidity and mortality between different SES groups have remained and even widened over time (Link and Phelan, 1995; Phelan, Link, Diez-Roux, Kawachi \& Levin, 2005). Consequently, this document explores the relationship between SES, proxied by educational attainment, and two health-related behaviors, which are central to explain better health-related outcomes: physical activity and food consumption habits. These two behaviors have been linked to the prevention of numerous diseases (Gaziano \& Gaziano, 2018): obesity, cardiovascular illnesses, diabetes, chronic renal malfunction, and even cancer (note that these correspond precisely to the top killers in medium- and high-income countries). In this respect, even newer branches of medical research have a say: it seems possible that lifestyle choices can be embedded in the human genome, passing from parents to offspring the consequences of good or bad health-related choices, that might later express themselves in terms of the onset of some illnesses (Vineis, Stringhini \& Porta, 2014).

While the relationship between non-communicable diseases (NCD) ${ }^{1}$ and health-related behaviors is clearly defined for high-income countries, less clear results have been found for middle-income countries. In particular, the latter group presents a transitional pattern in which health indicators start to resemble what is observed in developed economies, yet still present some patterns found in low-income countries (Miranda, Kinra, Casas, Smith \& Ebrahim, 2008). Accordingly, our primary motivation for this investigation is to determine where on the epidemiological transition ${ }^{2}$ Colombia is currently located. To establish this is fundamental in evaluating the present and future actions the government needs to take to avoid both higher prevalence of illnesses such as the ones discussed above, and the high health expenditures they entail. Yet before addressing this, it is first necessary to know how the level of education modifies health-related choices. The direction of the correlation between these variables will lead to more

\footnotetext{
${ }^{1}$ Defined as diseases that are not transmitted from person to person. They are long-run processes that are affected by genetics, the environment and behavior (WHO, n.d.)

${ }^{2}$ The epidemiological transition refers to the process in which infections are displaced as the top cause of morbidity and mortality in a country by "man-made" diseases. Some of the factors that are thought to influence this change are: medical advances and public health, socioeconomic, political and cultural shifts, and demographic changes (Omran, 2005).
} 
informed policy actions as a function of how the different levels of education may lead to different policy outcomes.

Before going any further, it is important to determine how Colombia behaves relative to its peers in terms of both health outcomes and health behaviors. Going from there, with a more informed hypothesis, we briefly explain what comes next in terms of identification strategy and main results.

\section{a. Colombia in the world: Health results and trends}

How is Colombia relative to countries of similar and higher levels of development in terms of health variables? Can we glance at what the future of the country looks like in this respect by looking to countries with similar growth paths?

Figure 1 shows the relationship between average income and the prevalence of obesity and overweight among adults for several countries ${ }^{3}$ of various levels of development. There is a marked direct relationship between income and the prevalence of these two conditions, which are narrowly related to the behaviors we intend to study here. What is more, Colombia is above the regression line, which means that, among this particular sample of countries, it presents a higher prevalence of obesity and overweight than what is expected given its level of development. Though many factors can help explain this pattern- like demographic changes, cultural believes and behaviors- this particular graph helps us open the debate on whether we can contribute to this set of factors from the behavioral perspective. Specifically, we search for the relationships between socioeconomic variables and different health-related attitudes.

Figure 1 Prevalence of obesity and overweight among adults vs. per capita GDP
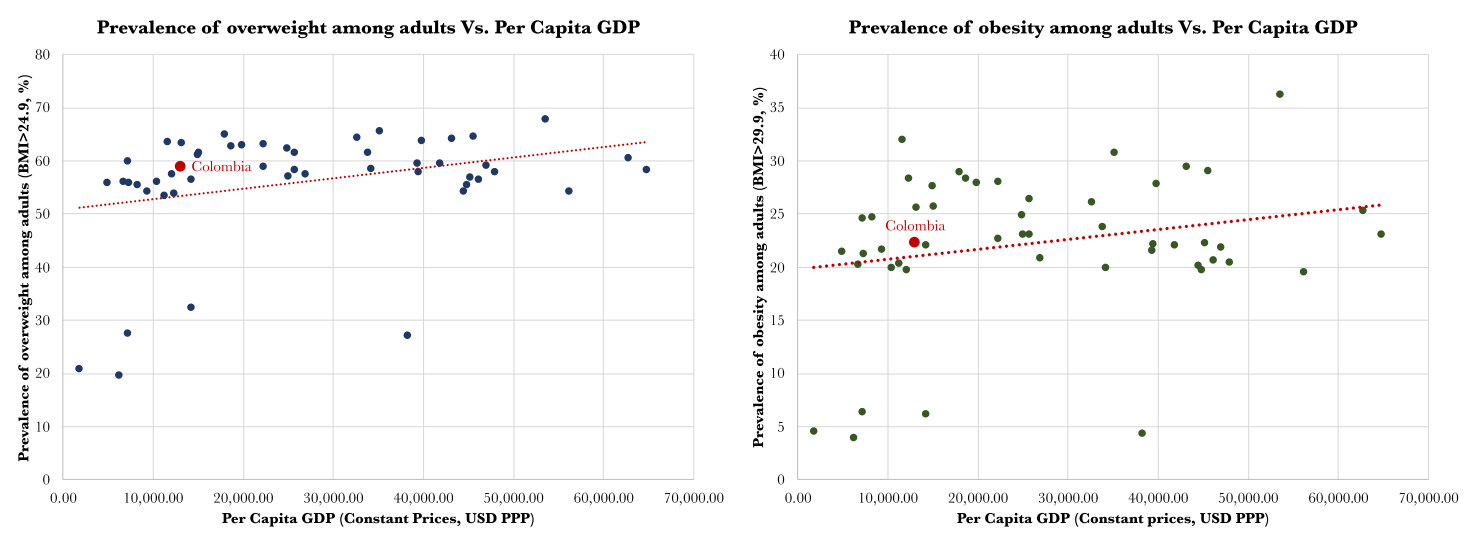

Source: World Health Organization, World Economic Outlook (IMF) 2018

\footnotetext{
${ }^{3}$ The countries in the sample are: Argentina, Australia, Austria, Belgium, Bolivia, Brazil, Canada, Chile, China, Colombia, Costa Rica, Denmark, Dominican Republic, Ecuador Egypt, El Salvador, Ethiopia, Finland, France, Georgia, Germany, Greece, Guatemala, Honduras, Hungary, Iceland, India, Ireland, Israel, Italy, Jamaica, Japan, Mexico, Netherlands, New Zealand, Norway, Panama, Paraguay, Peru, Philippines, Poland, Portugal, Russia, South Africa, Spain, Sweden, Switzerland, the United Kingdom, The United States of America, Uruguay, Venezuela.
} 
If we take a look at how Colombia behaves in terms of physical activity compared to some countries of similar development, then the story changes. Figure 2 shows the evolution of the prevalence of physical inactivity ${ }^{4}$ in adults (age-standardized estimates) between 2010 and 2016. Two things stand out from the graph: first, Colombia is the country in the sample with the highest prevalence of insufficient physical activity in adults in 2010 but managed to reduce it in over 20 percentage points in just six years. Furthermore, opposite to the other countries, Colombia presents a declining trend. Second, even with that drastic reduction, the country is still second in this list. This behavior seems counterintuitive at first glance since the trend for countries that are growing in economic and social terms is to decrease their levels of physical activity ${ }^{5}$. This as a consequence that, as people climb the economic ladder, they tend to use more sedentary means of transport as well as perform less physically demanding jobs. Does this change in physical inactivity is reflected in health outcome variables such as obesity and blood glucose levels?

\section{Figure 2 Prevalence of Insufficient Physical Activity- \%}

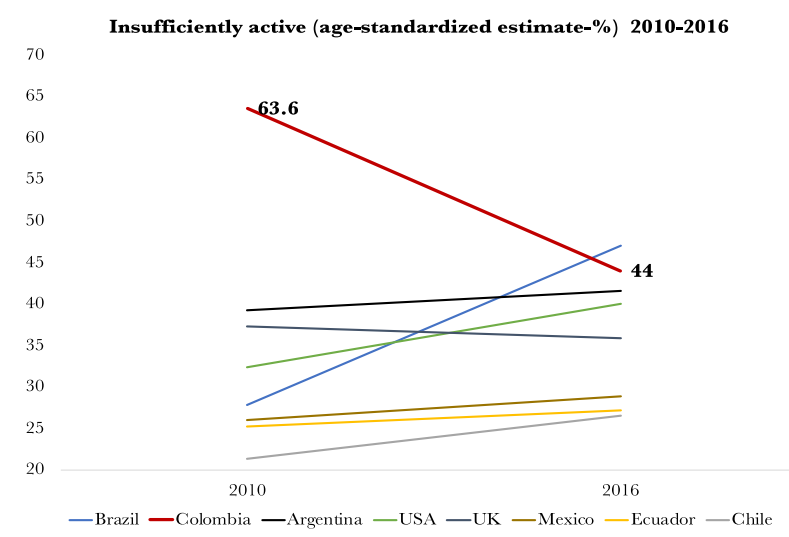

Source: World Health Organization

Figure 3 shows the evolution of the prevalence of two different health conditions intimately related to health habits such as food consumption and physical activity: overweight and raised blood glucose levels. Notice how Colombia follows the same upward trend as the rest of the countries in the sample. Nonetheless, it is not the most critical case in the list. How can we read Figure 2 and Figure 3 together? The first one suggests the country is still not behaving entirely as an industrialized country since it has managed to reduce its prevalence of physical inactivity in adults. Conversely, the second one shows the health of its general population is evolving like that of the rest of the world, and in particular as that of those

\footnotetext{
${ }^{4}$ Percent of defined population attaining less than 150 minutes of moderate-intensity physical activity per week, or less than 75 minutes of vigorous-intensity physical activity per week, or equivalent.

${ }^{5}$ This declining trend between 2010 and 2016 might be due to a number of factors: it is possible the level of physical activity in the population responds to different programs that aimed to improve people's lifestyle. On the other hand, these variables are subject to constant changes in measurement, which might affect the results when compared to previous years.
} 
countries who are following a similar path of development. Are there any differences in these indicators as a function of people's SES?

Figure 3 Prevalence of overweight and raised blood glucose in adults-\%
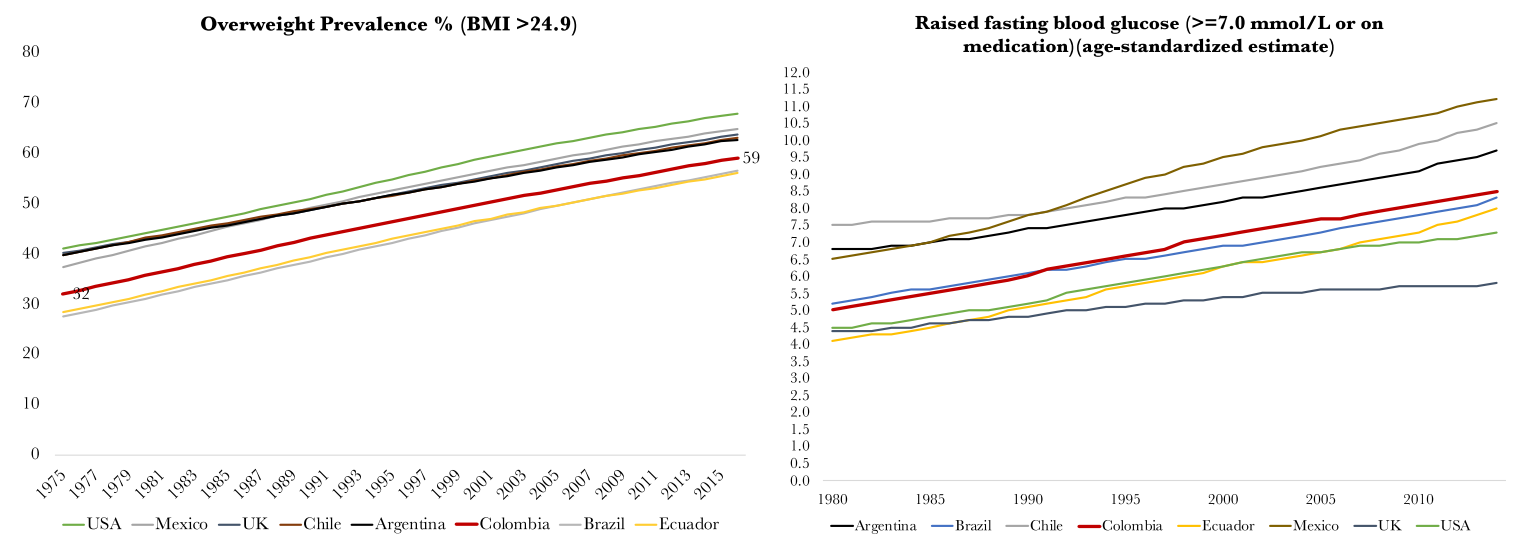

Source: World Health Organization

In the description of the data, we will see there are differences in some health outcomes, such as the Body Mass Index (BMI), as a function of years of education. For now, we study what Figure 4 shows on how people feel towards their health state. From Figure 4, as the level of wealth or education increases, the percentage of people that reports having not good or bad health falls, whereas the opposite is true for those who report having an excellent, very good or good health state. To know that there are tangible differences in the perception of health depending on the level of education or wealth and that these differences play against the most vulnerable population further fuels the need to research if there are factors that exacerbate or attenuate this pattern.

Figure 4 Self-Reported Health over Wealth Quintiles and Years of Education-\%
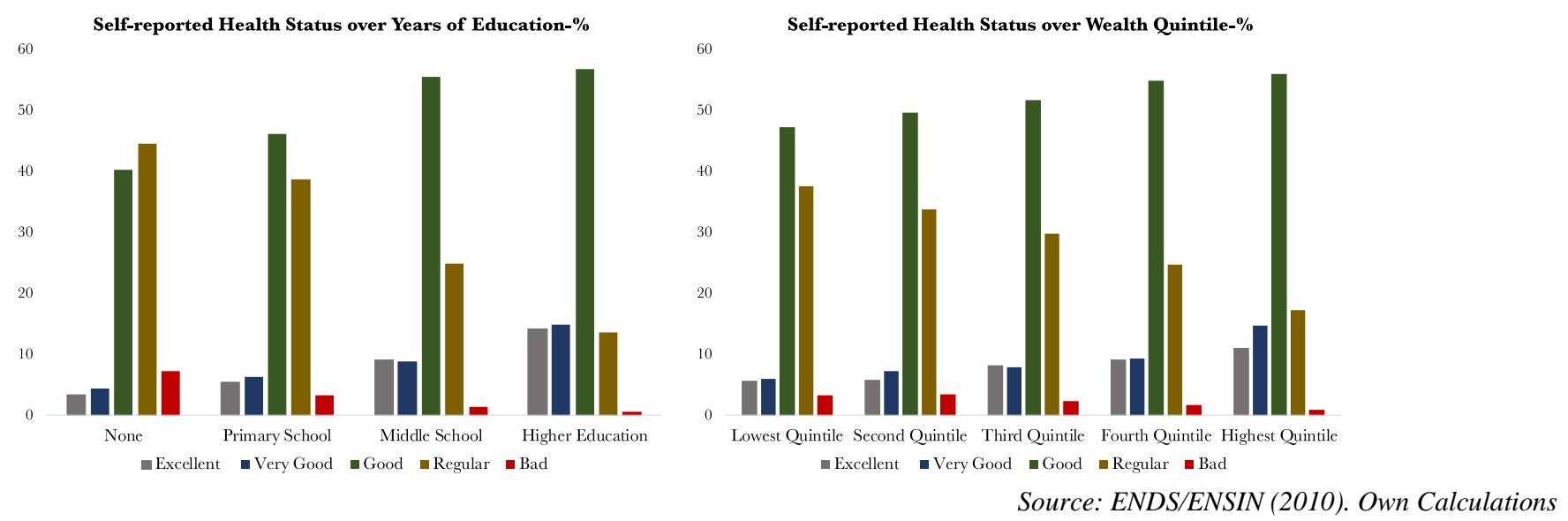

Finally, this section points to the hypothesis that health-related behaviors are more commonly observed in high SES individuals, though it is still unclear if there are protective factors that might help lessen this pattern. For instance, do low SES individuals exercise more because of their life setting? 
Causality is an elusive concept in most empirical studies, and this area of economics is no exception. Authors have had a hard time establishing causal links between different SES variables and health-related variables (whether they consider outcomes or behaviors). Nonetheless, through the use of different methodological approaches, many studies have found credible results. It must be noted that the majority of these papers were done for developed countries, whereas low- and middle- income economies present a severe shortage of this kind of studies.

With this in mind, our methodology has two main features, both attempting to control for possible sources of bias, particularly from omitted variables. The main characteristic is the use of a change in education laws as a source of exogenous variation in a 2SLS framework that could potentially correct the bias in the education coefficients. The use of this regulatory change is the center of the identification strategy because it allows us to talk about causality in a more reliable way. Furthermore, this particular decree, to the best of our knowledge, has not been exploited as an exogenous variation in similar studies on health economics in Colombia. The second characteristic, which aims to complement the identification strategy, is the inclusion of fixed effects at the municipality level and for the individual's year of birth (this will be clearer later), to control for all those unobserved factors associated either with the municipality the individual lives in, or with the year he/she was born.

Now, the decree's main goal was to increase the level of education of the general population. We will use this to our advantage, since a change in regulation is thought to be uncorrelated with those omitted variables that could be relevant in explaining educational attainment, and that could potentially be generating a bias. Indeed, we create a dummy variable that captures the workings of the decree (i.e., before and after) and use it as an instrument in a 2SLS model. Under certain assumptions, which we test in this article, we can talk about the causal impacts of educational attainment on our end variables. Our results indicate there is a positive relationship between educational attainment and the prevalence of physical activity, and the intake of fruits and vegetables. That association is more robust for the leisure physical activity models, while less conclusive outcomes were found for the transport-motivated exercise, which, as it will be explained, could be a good result. In the case of food consumption habits, though there is a positive relationship with education, it is not very robust. Conversely, when including wealth indicators, we find that access plays a crucial role in explaining the presence of this health behavior. We include variables that measure access to health services, which provide further insight into how SES impacts health-choices. As such, a byproduct of the central analysis is the interpretation of the results of the social security regime variables, which complement the former in important ways. 
The rest of the document is organized as follows: section two presents the literature review while section three focuses on the main results. Sections four and five describe the robustness and assumptions tests, respectively. Finally, section six concludes.

\section{Literature Review}

Though we are primarily interested in how health behaviors are affected by educational attainment, one first step would be to establish the link between socioeconomic status and morbidity and mortality. Given the methodological scope of this investigation, we intend to do this by exploring the related literature. To this end, the literature review is divided into three parts: 1) a brief review of medical research that connects habits and the onset of different diseases; 2) an analysis of the relationship between SES and the prevalence of some NCDs, particularly those with highly preventable risk factors; 3) a review of the association between SES and health behaviors, especially those related to NCDs.

\section{a. The link between health-habits and disease onset}

Several decades of medical research have established associations between certain habits and the subsequent development of some diseases. As early as 1940, the Framingham Study was set to investigate the epidemiology of cardiovascular diseases in the U.S. Such an effort, which has lasted over 70 years (Mahmood, Levy, Vasan \& Wang, 2014), has resulted in valuable understandings about the risk factors of cardiovascular diseases. For instance, the use of tobacco, an unhealthy diet, and physical inactivity have all been linked with a higher risk of presenting several cardiovascular illnesses (Gaziano \& Gaziano, 2018). In a similar fashion, the Surgeon General's Report in 1964 on smoking and health documented what was known at the moment about the connection between the use of tobacco and various ailments $\left(\right.$ Cutler \& Lleras-Muney, 2006) ${ }^{6}$. In the UK, a study of more than 3,000 necropsies found that men whose jobs were more physically demanding were less likely to have died of coronary heart disease (CHD) (Morris, Crawford, Raffle, Roberts \& Parks, 1953). Similarly, through the use of follow-up data of 20 years, authors in Sweden found that men who performed physically demanding jobs had lower mortality rates from coronary heart disease ${ }^{7}$. Additionally, men who performed leisure physical activity had a lower risk of death from all causes, including cancer and CHD (Rosengren \& Wilhelmsen, 1997).

Other conditions, such as diabetes mellitus also have a major component that depends on people's lifestyle, though its genetic elements are also essential in explaining its onset. The World Health

\footnotetext{
${ }^{6}$ In the present, it is known that cigarette smoking is one of the most important preventable causes of death, according to the CDC (1990). What is more, nearly $85 \%$ of lung cancers appear to be a result of smoking, including nonsmokers who are exposed to smoke (Warren \& Cummings, 2013).

${ }^{7}$ This result applies to all causes of death after controlling for other factors such as alcohol-drinking, smoking and occupational class.
} 
Organization (2016) estimates that over 422 million people over the age of 18 were living with diabetes in 2014, compared to 108 million in 1980: it has more than duplicated in less than 40 years. This increase means that the population living with diabetes grew 4.5 times faster than the global population and 3.5 times faster than the population between the ages of 15 and 64 years old in this same period (World Bank, n.d. $)^{8}$. Among the factors that explain this increase are demographic changes, greater life expectancy and changes in nutrition patterns (WHO, 2016). Of greater interest is type 2 diabetes ${ }^{9}$, which would previously develop in middle-aged people and the elderly but has had a surge in younger people (WHO, 2016). At the end of the 1990s, researchers noticed an increase in the prevalence of this illness in children and adolescents, especially in developed nations (Temneanu, Tandafir \& Purcarea, 2016).

\section{b. Socioeconomic status and non-communicable diseases}

We now inquire if there are disparities in different health outcomes that stem from differences in socioeconomic characteristics, such as income, educational attainment, and occupational status. It is worth noting that relations are not homogeneous across countries of different development levels and as such, our literature discerns between high-income countries and low and middle-income countries.

McLaren (2007), through a systematic literature review, examined the number of positive, negative, and non-significant associations between SES and obesity for men and women, in high-, middle- and lowincome countries. In high-income countries, there is a negative association between SES and the prevalence of obesity, while the opposite is true for low-income countries. The results were mixed and less conclusive for middle-income countries ${ }^{10}$. Similarly, Monteiro, Moura, Wolney \& Popkin (2004) conduct a literature review about the relationship between SES and obesity prevalence for developing countries and find that as a country reaches higher economic development, low SES individuals lose their protection against the development of obesity (men), or the relation is exacerbated (women). As McLaren (2007) mentions, it is possible this type of patterns responds to a sociocultural norm: in less developed countries, it is socially acceptable to have a higher weight in contrast to what is observed in richer countries. In the case of diabetes, the WHO (2016) finds that in high-income countries this disease is more prevalent among low SES individuals. In the case of middle and low-income countries, prevalence is

\footnotetext{
${ }^{8}$ Own calculations using the figures of the global population provided by the World Bank. The total population in 1980 was of 4.439 billion people, while in 2014 there were 7.271 billion people. For the population between the ages of 15 and 64 years old these numbers are 2.609 billion and 4.767 billion people, respectively.

${ }^{9}$ Though many factors are linked to the onset of type 2 diabetes, such as habits, the environment and genetic predisposition, obesity is one of the most important risk factors.

${ }^{10}$ For women in high-income countries, $63 \%$ of the associations were negative i.e. women of higher socioeconomic background presented lower levels of obesity. Only $3 \%$ were positive, while most associations for men were non-significant. When looking at countries of lower levels of income, the SES gradient in obesity gradually reverses itself: for women in middle-income countries the percentage of positive associations was $43 \%$ and for women in low-income countries it raises to 94\% (McLaren, 2007).
} 
highest among the wealthiest individuals, though the gradient seems to be reversing in some middleincome countries (2016). Finally, for high-income countries, it has been found that at lower levels of income, the risk of presenting some NCDs such as diabetes and, to some extent, Chronic Obstructive Pulmonary Disease (COPD) increase (Layte \& Whelan, 2008; Adler \& Newman 2002; Hosseinpoor, Bergen, Kunst, Harper, Guthold, Rekeve, Tursan d'Espaignet, Naidoo \& Chatterji, 2012).

These results can be framed under the "Fundamental Cause Theory" proposed by Link and Phelan (1995). The authors argue that health disparities have remained and even widened, in part because health outcomes are always changing. For example, in the first half of the 20th century, disparities in health were measured using mortality due to infectious diseases; once the SES gap in these health outcomes was closed, new disparities using new outcome variables emerged, i.e., diseases with a highly preventable component (Miech, Pampel, Kim \& Rogers, 2011). This is partly due to the use of flexible resources, such as knowledge and behavior, against negative health situations. What is more, this theory helps frame the behaviors observed in different segments of the population of a developing country. For instance, richer people tend to adopt behaviors and consumption patterns observed in more developed countries faster than their worse-off counterparts. If the behavior is later found to be "bad", then the richer are also quicker to abandon the behaviors, while their less fortunate peers are only starting to acquire the habit.

Several authors have empirically tested the theory (in the U.S), finding broad support to it. Miech et al. (2011) found that disparities in mortality are greatest for diseases that have a comprehensive stock of knowledge and technologies, which means that those with greater access to new treatments and technologies can more effectively prevent them and even treat them. Phelan et al. (2005) empirically test their theory and find those disparities in mortality are larger for more preventable diseases. Chang \& Lauderdale (2009) study how the SES gradient in cholesterol blood levels changed with the introduction of statins in the $1970 \mathrm{~s}^{11}$. Once the statins were introduced as a line of treatment, high SES individuals had access and enough knowledge to use them, thus reducing their blood cholesterol levels at a faster pace than low SES individuals.

For Colombia, it seems the pattern is not completely defined. A study in Medellín and its surrounding areas did not find a significant association between wealth and education, and the prevalence of conditions such as high blood pressure, and metabolic syndromes (Dávila, Quintero, Orrego, Ford, Walke, Arenas \& Ford, 2013). This is in line with findings from other studies, such as the one conducted by the WHO in several Latin American countries or the INTERHEART study (Lanas, Avezum, Bautista, Diaz, Luna,

\footnotetext{
${ }^{11}$ Prior to this technological advance, high cholesterol levels were more frequently seen among the wealthy.
} 
Islam, Yusuf, INTERHEART Investigators in Latin America, 2007; Gakidou, Mallinger, Abbott-Klafter, Guerrero, Villalpando, Lopez Ridaura, Aekplakorn, Naghavi, Lim, Lozanoa \& Murraya, 2011).

All in all, we can conclude that depending on the country's level of development individuals with high SES can be better or worse off in terms of the presence of NCDs. Certain factors that appear to protect low SES individuals against some conditions in low-income countries tend to disappear once the country achieves greater development (Monteiro et al., 2004). For instance, the fact that low-SES individuals perform more physical activity for transport reasons, or that they do more physically demanding jobs, can play in their favor against the onset of diseases linked to physical inactivity. This is key in explaining what is observed in middle-income countries, which are experiencing a form of epidemiological transition, in which demographic changes, a higher degree of automatization and changes in the patterns of consumption all play a role (Gaziano \& Gaziano, 2018; Kearney, 2010; Miranda et al., 2008).

\section{c. Socioeconomic status and health behaviors}

Health-related behaviors can account for between one fourth and one third of observed health disparities across socioeconomic groups (Link \& Phelan, 1995; Cutler \& Lleras-Muney, 2006). Authors have theorized about the SES variable that most robustly explains these associations. A significant part of the research has focused on the relation between education and health behaviors, though others have also evaluated the effect of income and occupational status, which are highly correlated to education.

Cutler and Lleras-Muney (2010) examine the education gradient on health behaviors using data from the U.S and the UK. They take smoking, drinking and obesity as their outcome variables and find that, controlling for several demographic characteristics, individuals with lower educational attainment are more likely to smoke, to drink, and to be obese. Furthermore, they evaluate the possible mechanisms through which education affects health habits. The most relevant ones among those are: cognitive ability (30\% of the gradient), knowledge (12\%), material resources (20\%), and social networks (10\%), while risk aversion and discount factors do not significantly contribute to the gradient (Cutler \& Lleras-Muney, 2010; Pampel, Rogers \& Denney, 2010). These findings led the authors to conclude that education modifies individuals' cognitive ability such as to improve the way they process information, rather than acting through a greater memory capacity. This is interesting when considering the wide availability of information people currently have on health and disease prevention ${ }^{12}$. However, they are careful to note that their results are correlations, i.e. they did not make causal associations. Similar results were found by Winkleby et al. (1992): people with greater educational attainment exhibited less frequently harmful

\footnotetext{
${ }^{12}$ Cutler and Lleras-Muney report on their 2010 study that though the Surgeon General Report of 1964 managed to reduce smoking among the entire U.S population, it did it to a greater extent among high SES individuals.
} 
health behaviors. In Finland, results show that smoking and physical inactivity were more common among low SES individuals (Lynch, Kaplan \& Salonen, 1998).

Concerning levels of physical activity, environment, trade-offs, and occupational status seem to be relevant factors. People of lower socioeconomic backgrounds tend to live in neighborhoods with few spots to practice physical activity safely (Wen et al., 2007; Powell, Slater, Chaloupka \& Harper, 2006). Nevertheless, less wealthy individuals tend to walk more for transportation and use public transport systems that are more physically demanding (bicycles for example), while also having jobs that are less sedentary, though this last one is slowly reversing in pro of automatization (Wen et al., 2007; Brownson et al., 2005; Giles-Corti \& Donovan, 2002; Berry, 2007). On the other hand, a poor diet in low SES individuals seems to be the result of a lack of access to fresh and high-quality food (Kearney, 2010). There is a trade-off between low-energy, dense food, and costs: food that has high degrees of energy (i.e., calories) tend to be less expensive than that with fewer calories and more nutrients (Drewnowski, 2009), which make them preferable for people with tight budget constraints.

For Colombia, a similar structure was found by González, Sarmiento, Lozano, Ramíerz \& Grijalba (2014). ${ }^{13}$ They found that people from higher strata tend to practice physical activity for leisure more frequently, while poorer individuals register higher levels of walking and bike-riding as a means of transport. A study conducted in 2005 in Bogotá (Colombia) found that the probability of being physically active for this population is of approximately 37\% (Gómez, Duperly, Lucumí, Gámez \& Vanegas, 2005). This probability was higher for males, people with more than 11 years of schooling, and those who report being in good health. However, the authors report there were no statistical differences in the probability of being regularly active as a function of socioeconomic status. Lastly, Dávila et al. (2013) found that physical activity was a protective factor against high blood pressure.

Regarding the use of methodologies that aim at correcting biases, Cawley and Ruhm (2011) find a number of articles that use instrumental variables as an identification strategy, seeking to establish causal links. For instance, Currie and Moretti (2003) use the number of college openings in the county as an instrument for women's education when studying the link between this variable and smoking. DeWalque (2007) uses college attendance, while Grimmard and Parent (2007) use draft avoidance strategies during the Vietnam war. Reinhold and Jürges use changes in fee laws in Germany, while Clark and Royer (2010) exploit changes in compulsory schooling in Britain. The list goes on, but one thing stands out: all empirical papers reviewed by Cawley and Ruhm (2010) correspond to the developed world. Not only is there less

\footnotetext{
${ }^{13}$ Their investigation focuses on patterns of physical activity during leisure time and for transport as a function of income, occupation, and education while stratifying by sex.
} 
literature in low- and middle-income countries regarding health behaviors, but it is also more scarce concerning articles that try to formulate an identification strategy that enables the authors to inquire about causal associations.

In sum, there are certain behaviors that negatively affect health outcomes, and that seem to be more frequently observed among individuals from lower socioeconomic backgrounds, especially in the developed world. This fact seems to echo on several health outcomes, especially in morbidity and, to some extent, in mortality. As said by previous authors (Miranda et al., 2008), the literature of low- and middleincome countries is far more limited than for high-income nations. In that sense, a country like Colombia may present different results in several behaviors. Currently, the closest study is the one made by González et al. (2014) in the physical activity analysis; however, we run a more extensive study by including nutrition as a dependent variable. Consequently, one contribution of this article will be to expand what is known about SES and health behaviors in middle-income countries, and in Colombia.

It is worth noting, however, that almost all the literature reviewed (including the González's article) lacks the methodological tools to talk about causality. As a consequence, we intend to extend what is known about health-related behaviors and education by applying a methodological framework that allows us to take a more rigorous approach to establish causal associations in the case of a developing country.

\section{Methodology}

\section{a. Data}

We use the Encuesta Nacional de Situation Nutricional (ENSIN) - which gathers information about people's lifestyles- and the Encuesta Nacional de Demografía y Salud (ENDS), both in Colombia from the year $2010^{14}$ (Box 1). Both databases work with the same household sample and thus share household and individual identifiers, so they can be easily merged. The ENSIN will provide information about nutrition and physical activity, anthropometric measures (height, weight, and BMI), and some sociodemographic variables. The ENDS complements those sociodemographic variables further ${ }^{15}$.

The ENSIN provides information about the two outcome variables:1) the time spent on physical activity, which allows us to estimate the total time (in minutes) per week of exercise; 2 ) the number of servings of fruit and vegetables per month, week or day. The recommendation from the World Health

\footnotetext{
${ }^{14}$ The ENDS was obtained from the DHS website, while the ENSIN was obtained with the help of the data center from the Economics Faculty in the Universidad de los Andes, and through the Ministry of Health. The data were collected by the INS and the ICBF (with which we hold a confidentiality agreement).

${ }^{15}$ In principle, we would also use a database that groups characteristics at the municipality level, as a consequence of the key role the environment plays in the incidence of physical activity, and the readiness of finding certain types of food. However, as we will show later when using municipality fixed effects, the significance of these variables disappears. What is more, they induce perfect collinearity in the model and are automatically eliminated from the models. Consequently, it is not necessary to use this database in our main estimation.
} 
Organization for adults between the ages of 18 and 65, is 150 minutes per week of moderate-intensity activity, or 75 minutes of vigorous-intensity activity, or a combination of both (WHO, 2015). Likewise, for adults between the ages of 18 and 65 the WHO recommends the consumption of at least five portions $(400 \mathrm{~g})$ of fruits and vegetables per day (WHO, n.d.).

We limit our sample to adults between the ages of 25 and $65^{16}$. The lower bound is based on the fact that most people are well over their formal education phase by that age. Additionally, we limit our analysis to urban areas exclusively, because rural areas present different behaviors that might not be comparable to those found in urban zones. Finally, for the physical activity analysis, we exclude from our sample people that report a physical impairment or disability which prevents them from undertaking moderate or vigorous activities, as well as women that report being pregnant at the moment of the survey.

\section{b. Description of the data}

In Colombia, the sample for the survey contains information for 204,459 individuals from 50,670 households located in 258 municipalities from all 32 departments ${ }^{17}$. The survey has national coverage, it is representative for urban and rural areas, for the 6 regions, 14 sub-regions, and 32 departments. We avoid bias from the differences in sample and population distributions (due, for instance, to errors in sampling), by using sampling weights in all our estimations and calculations ${ }^{18}$.

The physical activity questionnaire was administered to adults between the ages of 18 and 64 living in urban areas, which resulted in 14,465 observations with a response rate of $81.9 \%$. Because we limit our sample to people over 25 years of age with no reported physical impairments, and no women that were pregnant at the moment of the survey, we keep 11,549 observations. In turn, the consumption questionnaire was done on individuals between the ages of 5 and 64 years both in rural and urban zones, yielding 17,897 observations and a response rate of $89.7 \%$. Dropping information of individuals younger than 25 and those in rural areas leaves us with 3,629 observations.

Before presenting statistics of our main variables of interest, it is important to mention that not all physical activity is accounted for in the same way. This is especially true when comparing moderate physical activity and vigorous physical activity. Regarding the former, a person is required to undertake 150 minutes weekly to achieve the WHO goal, while the same is true with only half the amount of time

\footnotetext{
${ }^{16}$ Both surveys do not interview people older than 64 years old, however that segment of the population would have been excluded anyway because after that age disparities in health tend to disappear: health conditions associated with old age are almost impossible to effectively treat or prevent, no matter the resources.

${ }^{17}$ Colombia is divided in 32 administrative units known as "Departamentos", or departments, which in turn are divided into municipalities.

18 The DHS (ENDS in Spanish) standard sample design is a stratified two stage probability procedure.
} 
of vigorous activity. With this in mind, and following González et al. (2014), we multiply the amount of vigorous activity by two, to factor in these differences in intensity.

A similar analysis could be made, by studying the number of servings per day of fruits and vegetables in separate regressions. Indeed, the patterns of consumption between those types of food are not the same, as they each possess characteristics that alter the way in which people consume them. For instance, most fruits can be consumed in almost any moment of the day, while vegetables are usually eaten with certain meals. Though we acknowledge these differences in the consumption patterns of fruits and vegetables, we choose to make the analysis of the servings conjunctly. This as a consequence of the fact that, in terms of socioeconomic variables we cannot identify similar differences that may significantly add to our analysis.

\section{Table 1 Descriptive Statistics}

\begin{tabular}{|c|c|c|c|c|c|c|c|}
\hline & Obs & Mean & Std. Deviation & & Obs & Mean & Std. Deviation \\
\hline Physical Activity SubSample & & & & Consumption SubSample & & & \\
\hline Age (years) & 11,551 & 41.94 & 4.27 & Age (years) & 3,629 & 40.40 & 11.29 \\
\hline Sex & 11,551 & 0.42 & 0.49 & Sex & 3,629 & 0.33 & 0.47 \\
\hline Education (years) & 11,034 & 9.2 & 10.90 & Education (years) & 3,629 & 9.47 & 4.31 \\
\hline Wealth Score & 11,551 & 0.45 & 0.75 & Wealth Score & 3,629 & 0.46 & 0.75 \\
\hline Social Security Regime & & & & Social Security Regime & & & \\
\hline Contributive & 11,505 & 0.52 & 0.50 & Contributive & 3,610 & 0.54 & 0.50 \\
\hline Subsidized & 11,505 & 0.33 & 0.47 & Subsidized & 3,610 & 0.32 & 0.47 \\
\hline Special & 11,505 & 0.03 & 0.18 & Special & 3,610 & 0.03 & 0.18 \\
\hline Not Affiliated & 11,505 & 0.11 & 0.31 & Not Affiliated & 3,610 & 0.10 & 0.30 \\
\hline Occupation & & & & Occupation & & & \\
\hline Employed & 11,546 & 0.66 & 0.47 & Employed & 3,618 & 0.64 & 0.48 \\
\hline Unemployed & 11,546 & 0.03 & 0.18 & Unemployed & 3,618 & 0.03 & 0.16 \\
\hline Inactive & 11,546 & 0.31 & 0.46 & Inactive & 3,618 & 0.34 & 0.47 \\
\hline Owns Motorcycle & 11,546 & 0.22 & 0.41 & Owns Refrigerator & 3,620 & 0.87 & 0.34 \\
\hline Owns Car & 11,546 & 0.15 & 0.36 & & & & \\
\hline Education of the mother (years) & 5,745 & 7.48 & 4.82 & Education of the mother (years) & 2,098 & 8.27 & 5.05 \\
\hline Leisure Physical Activity (min/week) & 11,551 & 88.44 & 212.39 & Consumption of Fruits (servings/day) & 2,640 & 1.94 & 1.28 \\
\hline Transport Physical Activity (min/weeh & 11,551 & 233.06 & 379.44 & Consumption of Vegetables (servings/day) & 2,280 & 1.01 & 0.67 \\
\hline Total Physical Activity (min/week) & 11,551 & 321.51 & 449.92 & Consumption of Fruits and Vegetables (servings/d & 3,000 & 2.49 & 1.67 \\
\hline BMI (kg/m2) & 11,544 & 25.68 & 5.90 & ||BMI( kg/m2) & 3,626 & 26.53 & 4.90 \\
\hline
\end{tabular}

Table 1 describes the number of observations, the mean and the standard deviation for the key variables we will consider later. Looking over the right panel, one thing that stands out is the difference between the average amount of time invested in leisure physical activity relative to that undertaken for transportation. In a broader perspective, on average, people meet the WHO recommendations for physical activity when the transport component is included. The mean schooling is roughly 9 years, meaning that on average people complete basic education. This contrasts with the results for the education of the mother, that stands near 7.5 years of schooling. Likewise, the left panel also contains the number of observations, the mean and standard deviation for the subsample on which the consumption habits questionnaire was applied. Accordingly, people consume an average of 2.5 servings of fruits and vegetables a day, well below the WHO recommendations of 5 servings a day. Similar to the previous table, people have an average of 9.5 years of schooling. A final remark must be made regarding the average Body Mass Index 
(BMI), which with the use of sample weights corresponds to the average $\mathrm{BMI}^{19}$ for urban Colombia. According to the ENSIN, urban Colombians are above the 25-value-threshold, which means that, on average, Colombians living in cities or urban zones are overweight ${ }^{20}$.

The next two tables describe several difference-of-means tests in the level of education, to gauge if there is a pattern that could enlighten us further. Table 2 (top panel) describes different t-tests that compare the average years of education between people that report a positive or negative answer to each of the behaviors considered. Note that for all but one of the variables there is a statistically relevant difference between the mean years of schooling of both groups. Of those that are statistically significant, only one presents a negative sign: those who report using the bicycle for transportation possess lower levels of education. In contrast, the people who engage in leisure physical activity are better educated than those who do not. Does this mean that the people that perform more physical activity because they use the bicycle as a means of transport do so because they have no other option? Though it sounds extreme, the results from the table below signal that the choice of undertaking physical activity is different when it is done for leisure vs. when it is done for transportation reasons. In this same line, it is possible the education variable is also capturing other factors related to socioeconomic status, like the availability of time. Under this premise, the education variable would not only be capturing the workings of having higher level of study, but also the conditions that allow people to partake in leisure physical activity, or to be more active when transporting from one place to another.

\section{Table 2 Difference of Means of years of education by different health-related behaviors}

\begin{tabular}{ccccc} 
VARIABLES & Total & Yes & No & Difference \\
\hline Physical Activity Variables & & & & \\
Car & 8.87 & 9.49 & 7.04 & $2.45^{* * *}$ \\
Bike & 8.87 & 7.91 & 9.003 & $-1.085^{* * *}$ \\
Walking for Transport & 8.87 & 8.91 & 8.81 & 0.08 \\
Walking for Leisure & 8.87 & 9.21 & 8.78 & $0.43^{* * *}$ \\
Moderate P.A & 8.87 & 10.09 & 8.63 & $1.45^{* * *}$ \\
Vigorous P.A & 8.87 & 10.42 & 8.69 & $1.73^{* * *}$ \\
\hline Consumption Habits Variables & & & \\
Eats Fruit (Juice) & 9.15 & 9.37 & 7.05 & 2.32 \\
Eats Fruit (Whole) & 9.15 & 9.45 & 7.63 & 1.81 \\
Eats Vegetables (Cooked) & 9.15 & 9.44 & 8.28 & $1.15^{* * *}$ \\
Eats Vegetables (Raw) & 9.15 & 9.43 & 7.53 & $1.9 * * *$ \\
Consumes Soft Drinks & 9.15 & 9.45 & 8.39 & $1.06^{* * *}$ \\
Eats Candy & 9.15 & 9.74 & 8.53 & $1.2^{* * *}$ \\
\hline \multicolumn{5}{c}{ Standard Errors in parenthesis } \\
& $* * * \mathrm{p}<0.01, * * \mathrm{p}<0.05, * \mathrm{p}<0.1$ & \\
\hline
\end{tabular}

The bottom panel on Table 2 shows the same statistics, but for consumption variables. Hence, we now compare the differences in average schooling between those who claim consuming certain types of food

\footnotetext{
${ }^{19}$ Though is not a perfect measure for the presence of abnormal weights, it is generally regarded as a good indicator.

${ }^{20}$ According to the WHO, people above a BMI of 24.9 are considered overweight, while people above 29.9 are considered obese.
} 
against those who deny it. Observe that we include not only the consumption of healthy food but also those that are deemed as positively related to the development of obesity and diabetes, among others. Contrary to what we initially expected, all tests yield positive and significant differences. In other words, those who eat candy or consume soft drinks have significantly more years of education than those who do not. Similarly, those who consume fruits and vegetables also report having higher educational attainment. Our initial belief was that those with higher educational attainment would report consuming fruits and vegetables more frequently, while those with less education would report consuming unhealthy products more often. This could point that having access, both to healthy and unhealthy food, is key.

Table 3 Difference of Means of Years of Education and Wealth Score by Self-Reported Health Status

\begin{tabular}{|c|c|c|c|c|}
\hline & Total & Yes & No & Difference \\
\hline \multicolumn{5}{|l|}{ Education (years) } \\
\hline Excellent Health & 8.72 & 10.51 & 8.54 & $1.97 * * *$ \\
\hline Very Good Health & 8.72 & 10.39 & 8.54 & $1.81 * * *$ \\
\hline Good Health & 8.72 & 9.17 & 8.22 & $0.94 * * *$ \\
\hline Regular Health & 8.72 & 6.93 & 9.39 & $-2.46^{* * * *}$ \\
\hline Bad Health & 8.72 & 5.45 & 8.78 & $-3.33 * * *$ \\
\hline \multicolumn{5}{|l|}{ Wealth Score } \\
\hline Excellent Health & 0.23 & 0.39 & 0.21 & $0.19 * * *$ \\
\hline Very Good Health & 0.23 & 0.42 & 0.21 & $0.23^{* * *}$ \\
\hline Good Health & 0.23 & 0.26 & 0.19 & $0.07 * * *$ \\
\hline Regular Health & 0.23 & 0.005 & 0.28 & $-0.023 * * *$ \\
\hline Bad Health & 0.23 & -0.053 & 0.23 & $-0.28 * * *$ \\
\hline
\end{tabular}

Finally, Table 3 describes the statistical difference of the average wealth score and average years of education, by the self-reported health status. When the individuals report having not good or bad health, then, on average, they have 2.46 and 3.33 fewer years of education than those who do not report that. In contrast, those who answer having very good or excellent health have 1.81 and 1.97 more years of education. These differences support what Figure 4 shows on there being meaningful (and now significant) differences in the perception of health, that plays against the most vulnerable population. Whether these differences are due to disparities in the access to medical services or to the possibility that pro-health behaviors are more frequently seen in those better-off will be determined when we apply the identification strategy. In other words, through the methodology laid out in the next sub-section, we seek to determine if people with different socioeconomic backgrounds behave differently towards their health, controlling for several characteristics, like the affiliation to a social security regime.

\section{c. Empirical Strategy}

As mentioned before, we are using two types of outcome variables: physical activity, measured as amount of time per week a person performs physical activity, and consumption of fruits and vegetables, measured as servings per day. And so, we would like to estimate for each individual $i$ in municipality $m$ : 
Physical activity $_{i m}=X_{i m}^{\prime} \alpha_{0}+Y_{m}^{\prime} \alpha_{1}+\alpha_{2}$ Education $_{i m}+A_{i m}^{\prime} \gamma+\eta_{1 i m}$

Nutrition $_{\text {im }}=X_{\text {im }}^{\prime} \beta_{0}+Y_{m}^{\prime} \beta_{1}+\beta_{2}$ Education $_{\text {im }}+A_{\text {im }}^{\prime} \gamma+\eta_{\text {2im }}$

Where $X_{i m}^{\prime}$ is a set of covariates at the individual and household level (sex, age and age ${ }^{2}$, ethnicity/ race, marital status, occupational status, type of family), and $Y_{m}^{\prime}$ is a set of characteristics at the municipality level (size of the municipality, availability of recreational places, climate, level of investment in public health, violence). Education im $_{\text {in }}$ is the level of education of individual $i$ in municipality $m$, measured as the number of years of schooling (highest level achieved). $A^{\prime}{ }_{i m}$ is a set of unobserved characteristics for individual $i$ in municipality $m$, which are relevant in explaining each of the behaviors in Equations (1) and (2), and that are also related to the level of education. These unobserved characteristics range from the intrinsic motivation a person has, to the self-efficacy he/she possesses. For instance, a more motivated individual could study more years, even in the face of economic hardship, and at the same time have better health-related habits, even when he/she has the (more comfortable) option of a sedentary life and an unhealthier diet. Likewise, self-efficacy has been linked to the belief an individual has on being capable of accomplishing his/her goals. Though it is a rather new concept, it is possible that those with greater self-efficacy can reach higher levels of education and have better health habits than those with less self-efficacy. Time preferences might also have a role: more educated people might be able to develop more patience, i.e. a larger value for future benefits.

As a result, neither one of those equations can be estimated without bias. More specifically, the relation between unobserved characteristics with the dependent variable and with education generates an Omitted Variable Bias (OVB). Consequently, we estimate equations (3) and (4), not without bias:

$$
\begin{aligned}
& \text { Physical activity }_{i m}=X_{i m}^{\prime} \alpha_{0}+Y_{m}^{\prime} \alpha_{1}+\alpha_{2} \text { Education }_{i m}+\varepsilon_{1 i m} \\
& \text { Nutrition }_{\text {im }}=X_{\text {im }}^{\prime} \beta_{0}+Y_{m}^{\prime} \beta_{1}+\beta_{2} \text { Education }_{\text {im }}+\varepsilon_{2 i m} \\
& \text { Where } \quad \varepsilon_{1 i m}=A_{\text {im }}^{\prime} \gamma+\eta_{1 i m} \\
& \varepsilon_{2 i m}=A_{i m}^{\prime} \gamma+\eta_{2 i m}
\end{aligned}
$$

As a first step towards dealing with the endogeneity produced by omitted variables, we include time $\left(Y o B_{i m}^{\prime}\right)$, and municipality (Munip $p_{i m}^{\prime}$ ) fixed effects. This allows us to control for two different groups of "characteristics": the municipality fixed effects control for all those (stable) factors that occur at each municipality and that might affect our variables of interest, thus eliminating this source of potential bias. In a similar fashion, the time fixed effects, which in reality are fixed effects for the individual's year of 
birth, absorb the effect of all those factors that might affect a person or the outcome variable in function of the year he/she was born ${ }^{21}$.

Physical activity $_{i}=X_{i}^{\prime} \alpha_{0}+\alpha_{1}$ Education $_{i}+Y_{o} B_{i}^{\prime} \gamma+$ Munip $_{i}^{\prime} \delta+\varepsilon_{1 i}$

Nutrition $_{i}=X_{i}^{\prime} \beta_{0}+\beta_{1}$ Education $_{i}+$ YoB $_{i}^{\prime} \gamma+$ Munip $_{i}^{\prime} \delta+\varepsilon_{2 i}$

The second step towards eliminating bias from our estimation involves exploiting a change in the regulation concerning primary and middle education, as well as the restructuring of the Ministry of Education. Decree 088 issued in 1976 broadened the concept of basic education, by adding four years of middle schooling to the initial five years of primary schooling, which start around the age of 6 . What is more, those five years of primary schooling became compulsory (Ramírez \& Tellez, 2006). It is easily seen why this sort of change is appealing when dealing with OVB. In our case, this regulation provides a way of explaining (to a certain extent) the number of years of education for an individual potentially affected by the decree, and at the same time, it appears to be uncorrelated with unobserved factors that help explain health-related choices. That is, it is a source of exogenous variation uncorrelated with variables that might affect the outcome variable. In other words, this change of regulation happened outside the control of the individuals affected by it. Consequently, factors such as motivation or selfefficacy, which we cannot account for and are a potential source of bias, are not correlated with the implementation of the decree. Furthermore, combining the use of the decree the fixed effects allows us to strengthen our strategy further. For instance, the municipality fixed effects capture possible heterogeneities in the implementation of the decree between locations.

In essence, our empirical strategy constitutes an instrumental variables model that uses as a source of exogenous variation the changes in regulation brought about by the 1976 Decree. Indeed, using this decree as an instrument provides a feasible way of dealing with the OVB, since it changes the conditions of education on the supply side, rather than the demand side. The first model exploits this variation using dummy variables, which in turn, makes our strategy very similar to a differences-in-differences approach in a longitudinal framework (i.e., we take advantage of the time dimension in the data through the year in which the Decree was issued). Typically, we would need to construct a dummy variable that proxies exposition to the effects of the decree. In principle, we can achieve this by setting a birthyear threshold that marks the time people needed to be born to be covered by the decree. However, if we want to continue to use the year of birth fixed effects, using a threshold year as a variable alone will not suffice. Thus, we

\footnotetext{
${ }^{21}$ By including municipality fixed effects, the need to use control variables at this level disappears, since they will generate perfect multicollinearity with the municipality dummy variables. Hence, we exclude them hereafter, as well as the municipality index.
} 
construct a variable that proxies exposition to the new regulation, under the assumption that it affects subjects in a heterogeneous way.

The variable that functions as a proxy of exposition is the education of the mother. In particular, the individuals in our sample whose mothers reached no more than middle schooling, belong to the exposed group, while those whose mothers' highest educational attainment is some way of college education will be placed in the "unexposed" group. The reasoning behind this is that the individuals whose mothers have high educational attainment would have entered primary school- or stayed through middle school- with or without the decree. In contrast, those whose mothers are not as educated might have altered their education decisions based on what the decree did to increase the attendance rates. Furthermore, it is likely that people with mothers with low educational attainment went to public institutions, which further increases the likelihood of being exposed to the effects of the change in regulation.

Before presenting the equations that use the source of exogenous variation (the decree), it is required that such regulation effectively changes the number of years of education of the individuals in the database. This is equivalent to estimating the first stage of years of education as a function of the instrument and a set of exogenous covariates.

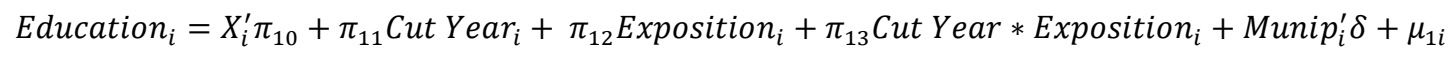

Equation 7 shows that first stage, when including the dummy for the cut year instead of including year of birth fixed effects. Since we do not want to lose the benefits of using time fixed effects, we run Equation 8 , in which we no longer use the cut year dummy variable and include birth year fixed effects.

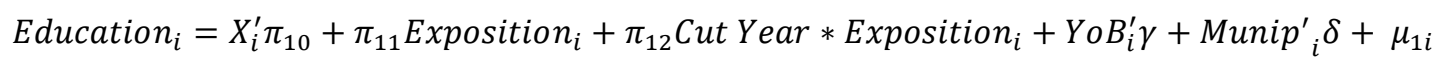

The next logical step is running the second stage, which includes the education fitted values from the first stage and the same set of covariates and fixed effects. This allows us to extract the exogenous variation of the change in regulations, differentiating between two types of groups: those exposed because they were born at the right time and their mothers had the "right" level of education", and those who were not exposed to the effects of the new regulations.

$$
\begin{aligned}
& \text { Physical activity }_{i}=X_{i}^{\prime} \alpha_{0}+\alpha_{1} \text { Ed } \widehat{\text { ucatıon }}_{\iota}+\alpha_{2} \text { Exposition }_{i}+\text { YoB }_{i}^{\prime} \gamma+\text { Munip }_{i}^{\prime} \delta+\varepsilon_{1 i} \\
& \text { Nutrition }_{i}=X_{i}^{\prime} \beta_{0}+\beta_{1} \text { Educatıon }_{\iota}+\beta_{2} \text { Exposition }_{i}+\text { YoB }_{i}^{\prime} \gamma+\text { Munip }_{i}^{\prime} \delta+\varepsilon_{2 i}
\end{aligned}
$$

Equations (9) and (10) show the complete empirical strategy adopted for this article. It aims to deal with the endogeneity that arises from the Omitted Variable Bias by instrumenting the education variable with a change in the regulatory framework that is seemingly uncorrelated with the unobserved factors that are correlated to our end variables and education. Furthermore, we use municipality and birth year fixed 
effects to control for all possible (unobserved) characteristics that are determined either by the year of birth or the municipality in which individuals live in, as well as including several covariates.

Part of our empirical strategy also incorporates the fact that these two behaviors may not be a linear function of years of education. Hence, it is likely that education follows a quadratic form, meaning there could be an optimum number of years of education under which physical activity and/or consumption of fruits and vegetables are maximized:

Physical activity $_{i}=X_{i}^{\prime} \alpha_{0}+\alpha_{1}$ Education $_{i}+\alpha_{2}$ Education $_{i}^{2}+$ YoB $_{i}^{\prime} \gamma+$ Munip $_{i}^{\prime} \delta+\varepsilon_{1 i}$

Nutrition $_{i}=X_{i}^{\prime} \beta_{0}+\beta_{1}$ Education $_{i}+\beta_{2}$ Education $_{i}^{2}+$ YoB $_{i}^{\prime} \gamma+$ Munip $_{i}^{\prime} \delta+\varepsilon_{2 i}$

Two practical implications can be derived from this hypothesis. The first one is that the inclusion of square years of education is necessary to correct this type of model misspecification. The second one is that it is highly likely square years of education is also an endogenous variable. As we see it, we have two choices: we can either exclude the quadratic form of education from our models, with the risk of generating a new bias from model misspecification. Alternatively, we can search for a second instrument and run another first stage on square years of education as well (Angrist and Pischke, 2013). For the sake of academic rigor, we choose the latter. As things stand at this point, though, we have a just identified system, with one instrument for one endogenous variable.

Remember that our exposition variable is constructed from the level of education attained by the mother. So, instead of creating one dummy variable, we could use $J$ - 1 education categories as exposition dummies. The instruments are the interaction of these dummies with the year dummy variable. Hence, we would not have one exposed group, but several, which represent varying degrees of exposure to the effects of the change in the regulatory framework concerning basic education. This means that the likelihood of changing the education decisions decreases as the mother's educational attainment increases.

The equations for the two first stages would be as follows:

Education $_{i}=X_{i}^{\prime} \pi_{10}+$ Mother's Education $_{i}^{\prime} \eta_{1}+$ Interacted Dummies ${ }_{i}^{\prime} \eta_{2}+Y_{o} B_{i}^{\prime} \gamma+$ Munip $_{i}^{\prime} \delta+\mu_{1 i}$

Education $_{i}^{2}=X_{i}^{\prime} \pi_{10}+$ Mother Education ${ }_{i}^{\prime} \eta_{1}+$ Interacted Dummies ${ }_{i}^{\prime} \eta_{2}+Y_{o} B_{i}^{\prime} \gamma+$ Munip $_{i}^{\prime} \delta+\mu_{1 i}$

Similarly, the second stage for each of our variables of interest are presented below:

$P . A_{i}=X_{i}^{\prime} \alpha_{0}+\alpha_{1} E_{\text {Educatıon }}+\alpha_{2}$ Educatıon $_{l}^{2}+$ Mother's Education' $^{\prime} \psi+Y_{o} B_{i}^{\prime} \gamma+$ Munip $_{i}^{\prime} \delta+\varepsilon_{1 i}$

Nutrition $_{m}=X_{i}^{\prime} \beta_{0}+\beta_{1}$ Educatıo $_{\iota}+\beta_{2}$ Educatıon $_{l}^{2}+$ Mother's Education $^{\prime} \psi+$ YoB $_{i}^{\prime} \gamma+$ Munip $_{i}^{\prime} \delta+\varepsilon_{2 i}$

What type of choices does the decree affect most? On the one hand, the regulation makes primary schooling compulsory for all children around the age of six, which might point to the goal of increasing rates of schooling for this particular level. On the other hand, it expands the concept of basic education, 
so that it covers four years of middle school, which could have fostered people to continue their education beyond primary levels. Solving this question is vital to determine the most suitable year that establishes exposition in a temporal frame. Those born after a specific year were more likely to be exposed to the effects of the change in the regulations than those who were born before.

\section{Figure 5 Average years of education ${ }^{22}$}

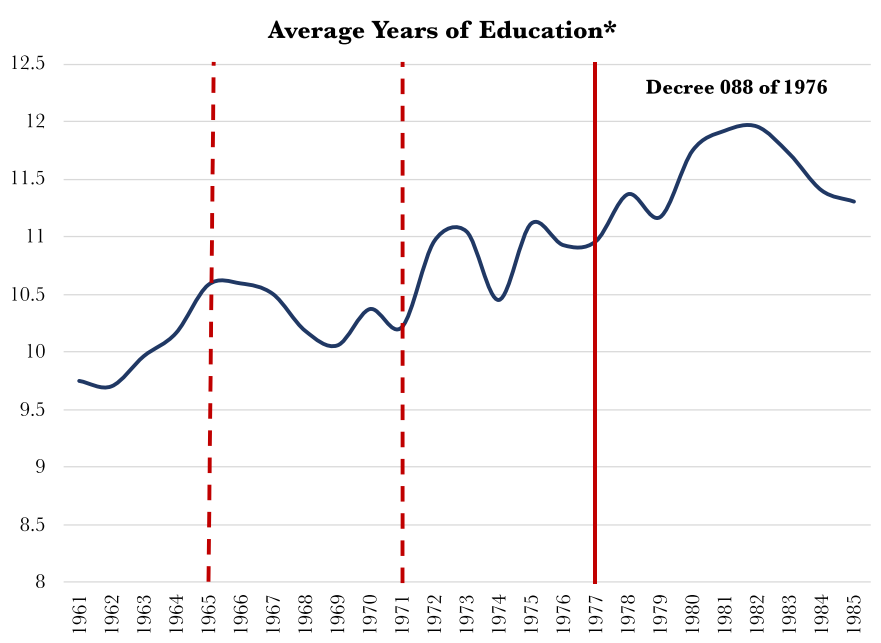

Source: ENSIN/ ENDS 2010. Own Calculations

If the decree affected the decision of going into primary school, the year of birth that must be taken as the threshold for exposition is 1970 or 1971, given that during the ages of 5 and 6 children start this type of education. Conversely, if the decree altered the choice of staying in school, and start secondary studies, then the year to be used as the threshold should be 1965. Based on Figure 5, there is stronger evidence suggesting the most relevant choice changed by the new regulation is the one of starting school, rather than that of staying. We define the dummy variables capturing the decree as follows:

$$
\begin{aligned}
& \text { Cut } \text { Year }_{i}=\left\{\begin{array}{c}
1, \text { if } Y o B_{i} \geq 1971 \\
0, \text { otherwise }
\end{array}\right. \\
& \text { Exposition }_{i}=\left\{\begin{array}{c}
1, \text { if Education of the } \text { Mother }_{i}<\text { College Education }^{\text {Ex }} \\
0, \text { otherwise }^{2}
\end{array}\right. \\
& \text { Exposition } 1_{i}=\left\{\begin{array}{c}
1, \text { if Education of the Mother } \text { Mo }_{i}=\text { Schooling } \\
0, \text { otherwise }
\end{array}\right. \\
& \text { Exposition } 2_{i}=\left\{\begin{array}{c}
1, \text { if Education of the } \text { Mother }_{i}=\text { Primary School } \\
0, \text { otherwise }
\end{array}\right. \\
& \text { Exposition } 3_{i}=\left\{\begin{array}{c}
1, \text { if Education of the } \text { Mother }_{i}=\text { Secondary School } \\
0, \text { otherwise }
\end{array}\right.
\end{aligned}
$$

\footnotetext{
${ }^{22}$ Using the ENSIN dataset, adjusted by individual sample weights. Though the Decree was issued in 1976, it came into effect in 1977.
} 
The Exposition dummy is used in the model that does not include the quadratic form of years of education, while Exposition 1-3 dummies are used in the one that does. In both cases, the base category is college education.

Finally, several assumptions must hold in order to effectively talk about causal links between education and physical activity or nutrition. More specifically, two assumptions must be made regarding our source of exogenous variation and the inclusion of fixed effects:

1) Relevance: The instrument must be correlated with the variable to be instrumented i.e. education.

$$
\operatorname{cov}\left(\text { Cut Year } * \text { Exposition }_{i}, \text { Education }_{i}\right) \neq 0
$$

The exogenous variation brought by the use of the decree must be effective in explaining the educational attainment in the individuals from the sample. Furthermore, due to the aim of the decree, its impact on the number of years of schooling must not only be robust but positive and non-negligible.

2) Exclusion restriction: The source of exogenous variation (i.e. the interaction between the two dummy variables that represent the decree) cannot be correlated with the unobservable characteristics that help explain the dependent variables, except via the level of education.

$$
\operatorname{cov}\left(\text { Cut Year } * \text { Exposition }_{i}, \varepsilon_{i}\right)=0
$$

The exclusion restriction also implies that there cannot be time-variant omitted variables, i.e. variables that impact the dependent variable across municipalities for which we cannot control for (Angrist \& Pischke, 2013). As a whole, the second assumption means that the change in the regulation regarding education must not influence those factors which we cannot account for and that explain today's healthrelated choices.

Evidently, the main challenges for this investigation lay on the assumptions. In particular, if one wants to talk about causality, then the two assumptions presented above must hold. To this end, section 5 presents robustness checks, whereas section 6 contains tests to verify if the assumptions hold.

\section{Results}

We now turn to analyze the results derived from running the different regressions. For clarity and organization purposes, we will study in separate sub-sections the results for physical activity and for consumption. Regarding the short regressions associated with the 2SLS estimations, they are presented in Appendix B and Appendix C.

\section{a. Physical Activity}

Table 4 presents the results of running the OLS and the 2SLS estimations on physical activity variables. The top panel displays the results from running the models under Equations (5) and (11), while 
the bottom panel does the same for Equations (9) and (15). The analysis is done on three separate variables: leisure, transport and total physical activity. We believe each of these captures a different decision regarding physical activity, and thus are impacted differently by socioeconomic conditions. For instance, under our central hypothesis, it is more likely to find a positive association between leisure physical activity and education with respect to transport physical activity. This as a consequence that the former involves a conscious decision of sparing time for that activity, while the latter might just be part of a routine that does not necessarily require a deliberate choice above other alternatives. However, this might also be the result of the more educated-affluent- people having more spare time to perform these activities. To address this, we include several covariates that aim to capture this channel.

Table 4 displays the results for the variable of interest (education) and the most important covariates. The full output ${ }^{23}$ from each of the models can be found in Appendix $\mathbf{B}^{\mathbf{2 4}}$ for consultation.

Table 4 Results from the physical activity models: OLS and 2SLS estimations

\begin{tabular}{|c|c|c|c|c|c|c|c|c|c|}
\hline & & \multirow{2}{*}{ Education } & \multirow{2}{*}{ Education $^{2}$} & \multirow{2}{*}{ Sex $($ Male $=1)$} & \multicolumn{3}{|c|}{ Social Security Regime } & \multicolumn{2}{|c|}{ Ownership } \\
\hline & & & & & Subsidized & Special & Not Affiliated & Motorcycle & Vehicle \\
\hline \multirow{6}{*}{ OLS Estimation } & Transport & -1.945 & & $109.7 * * *$ & $29.19 * *$ & -1.249 & $39.84 * *$ & $-44.90 * * *$ & $-84.53 * * *$ \\
\hline & & (1.238) & & $(10.65)$ & (12.30) & $(18.47)$ & $(17.07)$ & $(9.034)$ & $(12.42)$ \\
\hline & Leisure & $4.776^{* * *}$ & & $64.76^{* * *}$ & -1.677 & 24.96 & 5.141 & 8.222 & $20.88 * *$ \\
\hline & & $(0.657)$ & & $(5.959)$ & (5.188) & $(15.26)$ & $(8.257)$ & (7.217) & $(8.652)$ \\
\hline & Total & $2.831 * * *$ & & $174.4 * * *$ & $27.52 * *$ & 23.71 & $44.98 * *$ & $-36.67 * * *$ & $-63.65 * * *$ \\
\hline & & $(1.438)$ & & $(12.62)$ & (13.74) & $(25.44)$ & (19.78) & (12.06) & $(15.81)$ \\
\hline \multirow{6}{*}{$\begin{array}{l}\text { OLS Estimation } \\
\text { with Education }\end{array}$} & Transport & $12.40 * * *$ & $-0.773^{* * *}$ & $108.9 * * *$ & $29.50 * *$ & 3.575 & $39.45^{* *}$ & $-46.94 * * *$ & $-77.88 * * *$ \\
\hline & & $(4.334)$ & $(0.217)$ & $(10.65)$ & $(12.31)$ & (18.59) & (17.08) & (9.039) & $(12.48)$ \\
\hline & Leisure & 3.427 & 0.0727 & $64.83 * * *$ & -1.706 & 24.50 & 5.178 & 8.414 & $20.26^{* *}$ \\
\hline & & $(2.359)$ & $(0.135)$ & $(5.969)$ & (5.184) & (15.26) & (8.254) & (7.295) & $(8.681)$ \\
\hline & Total & $15.82 * * *$ & $-0.700^{* * *}$ & $173.7 * * *$ & $27.79 * *$ & 28.08 & $44.62 * *$ & $-38.53 * * *$ & $-57.63 * * *$ \\
\hline & & $(4.987)$ & $(0.258)$ & (12.63) & (13.75) & $(25.62)$ & (19.78) & (12.12) & $(15.83)$ \\
\hline \multirow{6}{*}{ 2SLS Estimation } & Transport & 24.24 & & 69.63** & $878.45^{* *}$ & -18.58 & 91.03*** & $-24.56 * *$ & $-106.5^{* * * *}$ \\
\hline & & (19.17) & & (28.19) & (36.53) & $(24.08)$ & $(33.23)$ & (12.49) & $(25.53)$ \\
\hline & Leisure & 11.01 & & $93.85^{* * *}$ & 14.61 & $34.53^{*}$ & 12.05 & -0.377 & 11.03 \\
\hline & & (13.26) & & (18.67) & (24.49) & (20.93) & (18.60) & (8.435) & (13.69) \\
\hline & Total & 35.32 & & $163.5^{* * *}$ & $102.1 * *$ & 15.96 & $103.1 * * *$ & -24.94 & $-95.44 * * *$ \\
\hline & & $(24.21)$ & & $(35.42)$ & $(45.48)$ & $(35.49)$ & (39.14) & $(15.86)$ & $(30.49)$ \\
\hline \multirow{6}{*}{$\begin{array}{l}\text { 2SLS Estimation } \\
\text { with Education }^{2}\end{array}$} & Transport & -75.55 & 4.493 & 89.25 & $58.20 *$ & .33 .13 & $76.30 * *$ & -7.203 & $-118.3 * * *$ \\
\hline & & (71.70) & (3.474) & (73.26) & (35.19) & $(30.85)$ & $(35.42)$ & (16.59) & (32.53) \\
\hline & Leisure & $89.73 * *$ & -3.325 & 34.30 & 31.13 & $42.33^{*}$ & 24.51 & -11.19 & 22.49 \\
\hline & & $(42.69)$ & $(2.054)$ & $(46.63)$ & (23.18) & $(24.11)$ & (21.38) & (11.47) & (16.81) \\
\hline & Total & 14.18 & 1.168 & 123.5 & $89.33^{* *}$ & 9.203 & $100.8^{* *}$ & $-18.39)$ & $-95.77 * *$ \\
\hline & & $(84.69)$ & (4.106) & $(87.88)$ & $(42.40)$ & $(42.65)$ & $(41.81)$ & $(20.81)$ & $(37.54)$ \\
\hline
\end{tabular}

From the first row of Table 4 (top panel), we find significant effects on leisure and total physical activity, both with positive signs: an additional year of schooling rises time of physical activity in 4.77

\footnotetext{
${ }^{23}$ Though several control variables at the individual, household and municipality levels were initially included, almost all became non-significant or were omitted because of perfect multicollinearity when including these fixed effects. The controls used in the estimations from here on are: sex, age, age ${ }^{2}$, social security regime dummies, occupation dummies, and ownership dummies. Later on, we will address the inclusion of the Decree dummies as well as the wealth score variable.

${ }^{24}$ Though not analyzed here, the inclusion of age and age ${ }^{2}$ suggest there is a maximum level of physical activity achieved under certain age, when the exercise is done for transport, but not in the case of leisure. Possibly, after certain age it is harder to commute using the bicycle or walking, whereas there are several physical activities done for leisure that do not require being "young".
} 
minutes and 2.83 minutes per week, respectively. In contrast, in the transport estimation, the coefficient that comes with education is negative and non-significant. When including the square form of years of education (second row, top panel), the education coefficient in the total physical activity model remains positive and statistically relevant in the linear term, while in the leisure estimation the coefficient loses significance, though it remains positive. Odd enough, under this model specification, in the transport estimation, the coefficient of education in its linear form turns positive and highly relevant. In this context, the behavior of the coefficient signals that, in effect, the physical activity variables are not a linear function of the education variable. Furthermore, the coefficient of the quadratic term- which is negative in all three models- points to a maximum amount of exercise per week, optimized by a certain level of studies.

Being part of the subsidized regime has a positive impact on the amount of physical activity done for transport, as well as the total amount performed, relative to the individuals from the contributive regime. The same is true for the ones that report not being affiliated to any form of social security regime. In contrast, these two coefficients are not significant in the leisure estimations. Unsurprisingly so, the special regime dummy is positive and significant in the latter, but not in the transport model. We include dummy variables for the ownership of motorcycles and vehicles and obtain somewhat expected results. For the transport estimation, the coefficients of both variables are negative and highly significant. Conversely, for the leisure models, the car-ownership variable presents a positive and relevant coefficient, while the motorcycle one is not significant. Up until this point, results seem to support the notion that higher SES means more time of physical activity performed weekly. However, they also point to the possibility that lower SES may also have a positive impact on physical activity when it is done for transportation motives.

It is important to underline that it is highly likely that these results are biased. In which direction does the bias work? On the one hand, it is possible that the unobserved characteristics that are not included in the regressions are positively correlated with education and physical activity, in which case we are overestimating the effect. On the other hand, if the omitted variables are negatively correlated with either educational attainment or level of exercise, then the bias will be towards zero. To this end, estimating the first $^{25}$ and second stages of the 2SLS models will shed light on this matter.

The first row from the bottom panel on Table 4 describes the results of running the 2SLS model in accordance with Equation (9), in all three physical activity variables used throughout this article. What stands out the most is the loss of significance of the education variable coefficients. The signs remain positive and the magnitudes of the coefficients in the three estimations are larger than their OLS

\footnotetext{
${ }^{25}$ All first stages from this chapter will be presented in the assumption-testing section.
} 
counterparts. However, this loss of statistical relevance can be the product of two things: on the one hand, it is possible that when correcting the bias through a 2SLS method we find that there is no effect of the level of education on physical activity. On the other hand, there is the possibility that due to the loss of efficiency when using 2SLS and the consequent growth of standard errors, the effects, though present, appear to be non-significant. When comparing the standard errors of the education variable in the OLS models versus the 2SLS estimations, we can perceive that indeed they are larger in the latter, which might support the second explanation. Furthermore, notice that the standard errors are smaller than the point estimates, which means that the coefficients are very close to being significant at the $10 \%$ level.

In general, the patterns studied in the OLS models are the same when switching to 2SLS: in the transport estimates the social security affiliation dummies have unchanged signs and significance, and the same goes for the motorcycle and car ownership variables. In the leisure model, variables are close to being significant at the $10 \%$ level: all standard errors are considerably smaller than the point estimates.

As stated in the methodology chapter, we consider the presence of non-linearities in the education variable, which led us to find a way of having more than one instrument, in order to include the quadratic form of this variable. Under Equation (15), we get somewhat different results than the previous models, though not wholly unexpected. In the leisure model, the coefficient of the linear education term is now significant at the $5 \%$ level and still positive, while the quadratic term is negative pointing to the presence of a maximum. In contrast, the transport estimates now yield a negative coefficient for the linear education variable, though its standard error is very close to the point-estimate, indicating it is far from being significant. Given that transport physical activity weights more in the total than the leisure component, we get a positive though smaller coefficient for linear education in the total physical activity model yet is, by no means, significant under any level.

Up until this point, we can derive several preliminary conclusions ${ }^{26}$ : first and foremost, there is evidence that supports the claim that education affects the amount of time people spend on physical activity per week. Moreover, this relationship is more robust and (usually) of greater magnitude for the leisure component, which is consistent with expectations. We find that, after controlling for potential sources of bias through the use of a source of exogenous variation, the marginal impact of greater educational attainment of leisure physical activity is around 11 minutes ${ }^{27}$ per week, on average. This might seem like small value, especially when considering the population that is far from reaching the

\footnotetext{
${ }^{26}$ Box 2 shows the results from this section when using the log-version of the physical activity variables.

${ }^{27}$ In the model that includes education ${ }^{2}$ the marginal impact of the variable is not a value, but a linear function. if we evaluate this function on the average years of schooling, we find that the marginal effect on this population is of over 20 additional minutes of leisure physical activity per week.
} 
recommended levels of exercise. Nonetheless, from a population point of view, this effect is not negligible. In fact, these results points to both the challenge and the potential benefits of having the Colombian population achieve greater levels of education.

Second, when focusing on the covariates, we find consistent results throughout the estimations, which also seems to support the idea that SES impacts health-related choices differently, depending on the behavior that is being considered. For the leisure part, it seems a higher SES positively impacts its undertaking, which is reflected in the coefficients of the social security affiliation dummies and on the car-ownership variable. On the other hand, having a motorcycle or a car is negatively associated with the physical activity done for transport. Furthermore, being part of the subsidized regime, or not being affiliated to any regime at all, is positively associated with the time of transport-physical-activity done every week. All in all, these results are in line with what has been previously found in other articles. This is especially true when considering the effect education has over the leisure physical activity as opposed to the lack of it for the transport component. Indeed, following González's investigation, we too found that SES determines which type of physical activity certain population undertakes more frequently. However, we go one step further when seeking to establish causal links between education and the dependent variables.

\section{b. Consumption of Fruits and Vegetables}

This second part of the results centers on what was obtained when applying the empirical strategy to the consumption variables. Table 5 shows the results of running models in accordance to Equations (6) and (12) in the case of the OLS models, and Equations (10) and (16) for the 2SLS models. ${ }^{28}$.

Table 5 Results from the consumption models: OLS and 2SLS estimations

\begin{tabular}{|c|c|c|c|c|c|c|c|c|c|}
\hline & \multirow{2}{*}{ Education } & \multirow{2}{*}{ Education $^{2}$} & \multirow{2}{*}{ Sex $($ Male $=1)$} & \multicolumn{3}{|c|}{ Social Security Regime } & \multicolumn{2}{|c|}{ Occupation (Base=Employed) } & \multirow{2}{*}{$\begin{array}{l}\text { Ownership } \\
\text { Refrigerator }\end{array}$} \\
\hline & & & & Subsidized & Special & Not Affiliated & Unemployed & Inactive & \\
\hline OLS Estimation & $\begin{array}{c}0.0853^{* * * *} \\
(0.0115) \\
\end{array}$ & & $\begin{array}{c}-0.277 * * * \\
(0.0959) \\
\end{array}$ & $\begin{array}{c}-0.257^{* * *} \\
(0.103) \\
\end{array}$ & $\begin{array}{l}0.0735 \\
(0.209) \\
\end{array}$ & $\begin{array}{c}-0.317 * * \\
(0.143) \\
\end{array}$ & $\begin{array}{l}-.0253 \\
(0.274) \\
\end{array}$ & $\begin{array}{l}0.0694 \\
(0.105)\end{array}$ & $\begin{array}{c}0.346^{* * * * *} \\
(0.126)\end{array}$ \\
\hline $\begin{array}{c}\text { OLS Estimation with } \\
\text { Education }^{2} \\
\end{array}$ & $\begin{array}{c}0.0199 \\
(0.0405) \\
\end{array}$ & $\begin{array}{c}0.00339 \\
(0.00212) \\
\end{array}$ & $\begin{array}{c}-0.274 * * * \\
(0.0957) \\
\end{array}$ & $\begin{array}{c}\left(-0.256^{* *}\right. \\
(0.103) \\
\end{array}$ & $\begin{array}{l}0.0750 \\
(0.209) \\
\end{array}$ & $\begin{array}{c}-0.305^{* * *} \\
(0.143) \\
\end{array}$ & $\begin{array}{l}-0.236 \\
(0.272) \\
\end{array}$ & $\begin{array}{l}0.0788 \\
(0.105) \\
\end{array}$ & $\begin{array}{c}0.348^{* * * *} \\
(0.125) \\
\end{array}$ \\
\hline 2SLS Estimation & $\begin{array}{l}0.0178 \\
(0.141) \\
\end{array}$ & & $\begin{array}{l}0.0771 \\
(0.287) \\
\end{array}$ & $\begin{array}{l}-0.339 \\
(0.287) \\
\end{array}$ & $\begin{array}{l}0.0867 \\
(0.327) \\
\end{array}$ & $\begin{array}{l}-0.325 \\
(0.243) \\
\end{array}$ & $\begin{array}{l}-0.621^{*} \\
(0.350) \\
\end{array}$ & $\begin{array}{c}0.108 \\
(0.125) \\
\end{array}$ & $\begin{array}{c}0.636^{* * * *} \\
(0.264) \\
\end{array}$ \\
\hline $\begin{array}{c}\text { 2SLS Estimation with } \\
\text { Education }^{2} \\
\end{array}$ & $\begin{array}{c}1.000 \\
(1.545) \\
\end{array}$ & $\begin{array}{l}-0.0523 \\
(0.0807) \\
\end{array}$ & $\begin{array}{c}0.104 \\
(0.806) \\
\end{array}$ & $\begin{array}{l}-0.337 \\
(0.287) \\
\end{array}$ & $\begin{array}{r}0.175 \\
(0.383) \\
\end{array}$ & $\begin{array}{l}-0.385 \\
(0.304) \\
\end{array}$ & $\begin{array}{l}-0.878 \\
(0.573) \\
\end{array}$ & $\begin{array}{l}0.0469 \\
(0.157) \\
\end{array}$ & $\begin{array}{c}0.588 * * \\
(0.264) \\
\end{array}$ \\
\hline
\end{tabular}

Going through the first regression output (first row, top panel), we find that education has a positive and significant effect on the number of servings of fruits and vegetables consumed daily, though the magnitude is quite small. Nonetheless, the significance disappears once we include the quadratic form of

\footnotetext{
${ }^{28}$ The covariates for the consumption models are age, square age, sex (male=1), social security regime, refrigerator ownership and occupation. In later estimations, we also include the exposition dummy from the decree and the wealth score.
} 
the variable (second row, top panel). Similar to what was found in the physical activity regressions, here too the social security variables tell a story about SES and health-related behaviors. The coefficient that comes along with the subsidized regime dummy is negative, meaning that those in this regime tend to consume fewer fruits and vegetables daily than their counterparts in the contributive regime. The same is true for the people that report not being affiliated to any social security regime. In contrast, the special regime dummy is positive, though non-significant. For the set of occupation dummy variables, we find that being unemployed is negatively associated with consumption of fruits and vegetables (relative to those employed). Lastly, we include a dummy that represents if the person owns a refrigerator, to capture the necessary economic conditions to buy fruits and vegetables and have where to store them safely. Unsurprisingly so, the sign of the coefficient is positive and significant at the $1 \%$ level.

Focusing on the 2SLS output, observe how once we correct the bias through the 2SLS estimation, the education coefficient lost its significance and even became smaller than it already was. On that same line, the social security variables also lost their significance. On the other hand, the variable on the refrigerator ownership dummy is still statistically relevant and of greater magnitude. These results do not diverge much when including the quadratic form of years of education in a 2SLS framework. From the 2SLS results, it is important to highlight that the coefficients for education not only lost their significance but also became smaller. It is almost as if, when attempting to correct the bias, the size of its effect on consumption variables is reduced. This could mean that the OBV was leading us to overestimate the effect education has on consumption habits in the OLS model.

At this point, we compare the size of the standard errors obtained in the 2SLS estimates against those from the OLS regressions. For instance, when looking over the standard error for the education variable, it can be seen that it grew considerably in the 2SLS estimates. This might signal that due to the loss of efficiency, the coefficients are less significant than in the OLS regressions because the standard error grew, rather than to the correction of the bias that leads to the disappearance of the effects of the variables included on the consumption habits. On the other hand, even if the coefficients found were significant (or close to be), their magnitude is very small. In contrast to what was found for physical activity, in the consumption pattern it seems that the benefits of greater education are not present, at least not for now. As a consequence, we must look into other social and economic characteristics when analyzing this particular health-related behavior.

The next logical question, then, is why the direction of the bias differs between physical activity behaviors and consumption habits? Remember that, in the OLS regressions for the physical activity variables, the sizes of the coefficients were smaller than their 2SLS counterparts, whereas the opposite is 
true for the consumption models. One possible explanation is that the factors that generate the bias in one and other estimation are not the same. For instance, access could be a key variable when looking over what people consume, but not always when analyzing physical activity. Though Colombia has an ample variety of fruits and vegetables throughout the year, we saw in the literature that highly caloric food products are crowding out fresh ones, especially in places that are worse off in socioeconomic terms. This can be particularly true in urban areas, on which this study is centered (Drewnowski, 2009).

Our results indicate that education has a role to play in explaining how people act regarding their health. Essentially, having more years of schooling impacts positively two specific health habits: physical activity and nutrition. They also suggest we must consider that the factors that we cannot observe and that play a role in explaining these attitudes are different for each one.

The next section intends to test the robustness of the results obtained using the outlined empirical strategy. The avid reader may have noticed that we are yet to include a measure of wealth in our regression. This was done to analyze how much of the effect found is due to having a certain level of income. Consequently, the first test consists on the inclusion of the wealth score, which will tell us how much of the effect found is due to access, rather than education. The second one estimates the first stage through an ordered logit and uses the fitted values as the instrument.

\section{Robustness Tests}

Our main goal in this section is to determine if the results obtained in the previous one hold when we alter one or several aspects of the empirical strategy. With this in mind, we propose two modifications. The first one concerns the inclusion of the wealth score: the change in the education coefficient will tell us how much of the effect found is due to access opportunities, rather than a change in the lifestyle choices due to a higher awareness a healthy living.

The second robustness test is related to the way we use the education variable. When we run the first stage using an OLS method, implicitly we are assuming that the variable is continuous. Nevertheless, this variable is constructed from the reported highest level of education, and the number of years studied at that level. As a result, the number of years in the survey is, in reality, a discrete variable. To factor this in, we decided to run the first stage through an ordered logit, in which each reported number of years of schooling is a different category. Furthermore, and following Angrist and Pischke's advice (2013), we use the fitted values from this regression as the instrument. In doing this, we incorporate the fact that the number of years of education is not continuous while preserving the essence of the 2SLS methodology, 
without falling in methodological mistakes ${ }^{29}$. In fact, when we use the fitted values derived from running the ordered logit, we are not actually using a predicted education variable, but rather the predicted cut points of the latent variable behind it.

\section{a. Test 1: Including the Wealth Score Variable in the Models}

Table 6 shows the results of running the 2SLS regressions on the physical activity variables when including the wealth index ${ }^{30}$. The top panel describes the results of including the linear form of the education variable, while the bottom panel does the same when including the quadratic form. Also, the first row on each panel shows the results when excluding control variables that are deeply connected with the score. For instance, many of the ownership variables are actually used in the construction of the index, so it seems natural to see how taking them out of the model changes the coefficients of the score. In the case of the social security regime dummies and the occupation dummies (not shown here), though they are not used in the construction of the wealth index, the latter is almost a determinant of the formers: those with better living standards tend to belong more often to the contributive or special regimes.

In addition to gauge how much of the effect education has on the dependent variables can be attributed to wealth conditions, including this variable will also help us capture other factors, such as spare time. Certainly, as we stated before, we can connect an individual's socioeconomic conditions to the amount of time he/she has free to perform leisure activities, including exercise. Having better socioeconomic conditions can be associated with less time-consuming jobs, less time dedicated to transporting from home to the workplace, among others. While we included covariates that help capture this channel, such as occupation, sex, and social security regime, by including the wealth score we further absorb those conditions that might correlate with education and wealth and that might be changing the effect of the former on the physical activity variables.

\footnotetext{
${ }^{29}$ According to Angrist and Pischke (2013), to estimate a nonlinear first stage when the endogenous variable is dummy or categorical is a Forbidden Regression, following Hausman (1975). An alternative, though, is to use the predicted values of the nonlinear first stage as the instrument, instead of plugging in directly that predicted variable in the second stage.

30 "Is a composite measure of a household's cumulative living standards. The wealth index is calculated using easy-to-collect data on household's ownership of selected assets" (DHS, 2018). It ranges from -3.16 to 1.48.
} 
Table 6 2SLS Estimations including the wealth score variable-Physical Activity

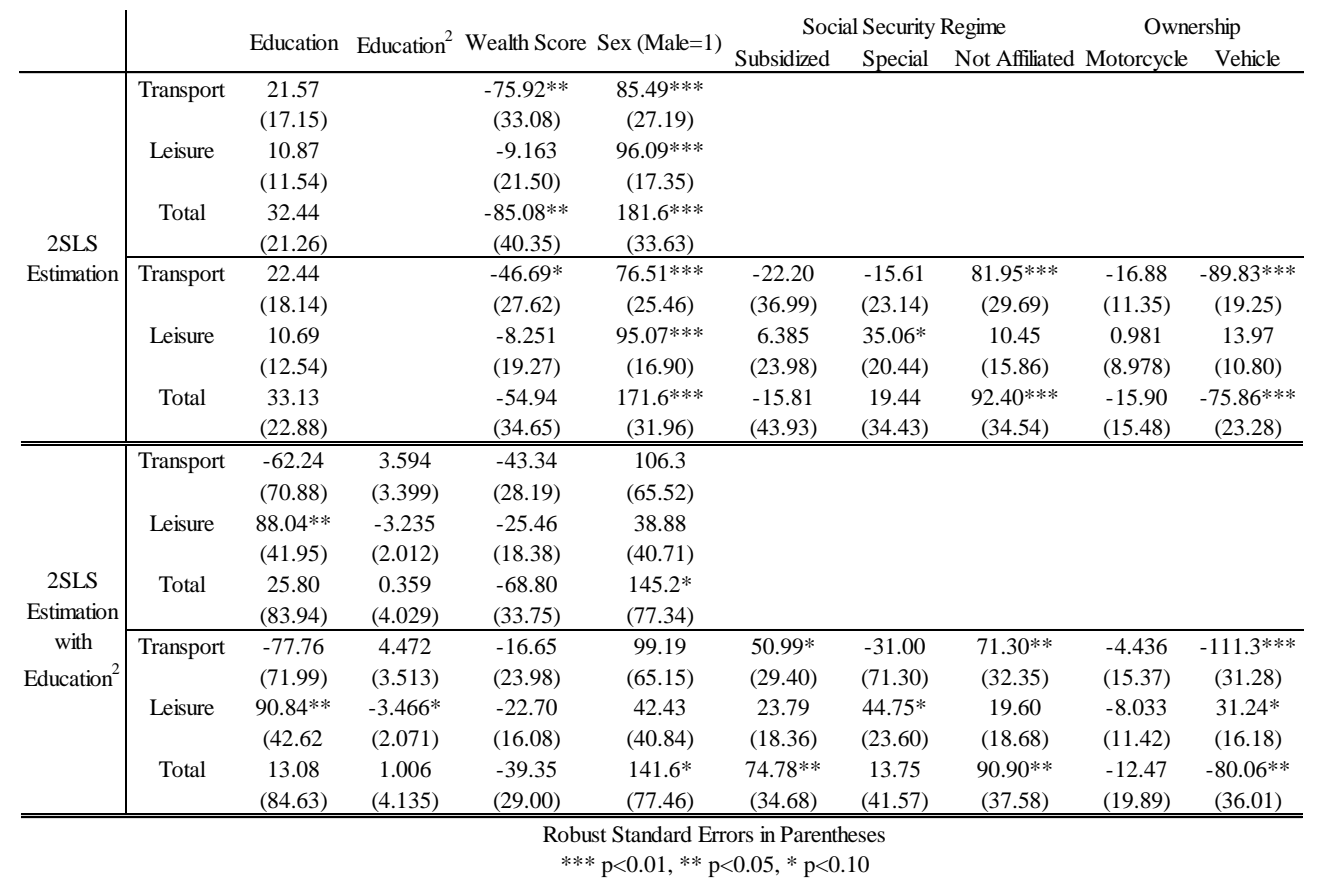

All in all, results do not significantly vary when including the wealth index in the regression models. Notice how the education coefficients are not significantly different from those presented in the bottom panel in Table 4. Furthermore, in the leisure estimation (bottom panel), observe that both coefficients for the education variables remain significant at the $5 \%$ and $10 \%$ level, respectively. Including the variables of ownership and social security regime reduces the significance of the score's coefficient, which means that when all these variables are included, they compete for the effect on the dependent variables. Furthermore, the score is negatively (and significantly) associated with performing transport physical activity, while the leisure component is unaffected by it. The behavior of the wealth index in these regression models also tells us that indeed it is helping us "clean out" the education coefficient from channels that are not directly related to the way education influences health-decisions, such as the amount of spare time.

Table 7 2SLS Estimations including the wealth score variable-Consumption Habits

\begin{tabular}{|c|c|c|c|c|c|c|c|c|c|c|}
\hline & \multirow{2}{*}{ Education } & \multirow{2}{*}{ Education $^{2}$} & \multirow{2}{*}{\multicolumn{2}{|c|}{ Wealth ScoreSex $($ Male $=1)$}} & \multicolumn{3}{|c|}{ Social Security Regime } & \multicolumn{2}{|c|}{ Occupation } & \multirow{2}{*}{$\begin{array}{l}\text { Ownership } \\
\text { Refrigerator }\end{array}$} \\
\hline & & & & & Subsidized & Special & Not Affiliated & Unemployed & Inactive & \\
\hline \multirow{4}{*}{ 2SLS Estimation } & 0.0315 & & $0.502^{* * *}$ & -0.0184 & & & & $-0.671^{*}$ & 0.0857 & \\
\hline & $(0.126)$ & & $(0.220)$ & $(0.242)$ & & & & $(0.358)$ & $(0.126)$ & \\
\hline & 0.0245 & & $0.421 * *$ & 0.0254 & -0.230 & 0.0439 & -0.319 & $-0.630^{*}$ & 0.120 & $0.370^{*}$ \\
\hline & $(0.138)$ & & $(0.177)$ & $(0.265)$ & $(0.249)$ & $(0.322)$ & $(0.241)$ & $(0.355)$ & $(0.124)$ & $(0.200)$ \\
\hline \multirow{4}{*}{$\begin{array}{l}\text { 2SLS Estimation with } \\
\text { Education }^{2}\end{array}$} & 0.533 & "-0.0275 & 0.494*** & 0.0284 & & & & $\begin{array}{l}-0.809 \\
\end{array}$ & 0.0476 & \\
\hline & $(1.336)$ & $(0.0707)$ & $(0.213)$ & $(0.617)$ & & & & $(0.503)$ & $(0.149)$ & \\
\hline & 0.940 & -0.0485 & $0.369 *$ & -0.0302 & -0.245 & 0.135 & -0.368 & -0.882 & 0.0583 & $0.362^{*}$ \\
\hline & $(1.557)$ & $(0.0813)$ & $(0.199)$ & $(0.725)$ & $(0.245)$ & $(0.376)$ & $(0.295)$ & $(0.568)$ & $(0.158)$ & $(0.205)$ \\
\hline
\end{tabular}

Likewise, in the case of the consumption of fruits and vegetables, we get that results remained unaltered after including the wealth index in the regressions. As with the physical activity estimations, 
this modification does not meaningfully alter the size, signs or significance of the education coefficients. Interestingly, and opposite to what was found for the physical activity variables, the index is positively correlated to the servings consumed per day of fruits and vegetables: an additional point in the index can increase the intake in as much as half a serving per day. Including or excluding the social security dummies or the ownership variable does not alter the significance of the wealth index coefficient in any of the four estimations. This points to the robustness of the effect of this variable in explaining consumption habits.

\section{b. Test 2: Estimating the First Stage with an Ordered Logit Model}

Since we are primarily focused on how changes in the empirical strategy affect the estimated effects of education on health-related choices. Given our space constraints we present the outputs from running the 2SLS models only. Those interested in the first stage ${ }^{31}$ results, may consult the output tables in Appendix B and Appendix C.

Table 8 2SLS Estimations using an ologit First Stage- Physical Activity

\begin{tabular}{|c|c|c|c|c|c|c|c|c|c|}
\hline & & \multirow{2}{*}{ Education } & \multirow{2}{*}{ Wealth Score } & \multirow{2}{*}{ Sex $($ Male $=1)$} & \multicolumn{3}{|c|}{ Social Security Regime } & \multicolumn{2}{|c|}{ Uwnership } \\
\hline & & & & & Subsidized & Special & Not Affiliated & Motorcycle & Vehicle \\
\hline \multirow{3}{*}{$\begin{array}{l}\text { 2SLS Estimation - } \\
\text { ologit First Stage }\end{array}$} & Transport & $\begin{array}{c}0.668 \\
(2.713)\end{array}$ & & $\begin{array}{c}92.80 * * * \\
(18.33)\end{array}$ & $\begin{array}{c}47.32 * * * \\
(15.83)\end{array}$ & $\begin{array}{l}-6.609 \\
(20.13)\end{array}$ & $\begin{array}{c}64.53 * * * \\
(21.99)\end{array}$ & $\begin{array}{l}-17.92 \\
(10.95)\end{array}$ & $\begin{array}{c}-82.45 * * * \\
(15.45)\end{array}$ \\
\hline & Leisure & $\begin{array}{c}4.117 * * \\
(1.635)\end{array}$ & & $\begin{array}{c}100.6 * * * \\
(13.18)\end{array}$ & $\begin{array}{c}2.876 \\
(8.477)\end{array}$ & $\begin{array}{l}38.03 * \\
(19.14)\end{array}$ & $\begin{array}{c}4.306 \\
(10.75)\end{array}$ & $\begin{array}{c}1.567 \\
(8.978)\end{array}$ & $\begin{array}{c}18.05 \\
(11.03)\end{array}$ \\
\hline & Total & $\begin{array}{c}4.784 \\
(3.259)\end{array}$ & & $\begin{array}{c}193.4 * * * \\
(23.43)\end{array}$ & $\begin{array}{c}50.19^{* * *} * \\
(18.24)\end{array}$ & $\begin{array}{c}31.42 \\
(31.40) \\
\end{array}$ & $\begin{array}{c}68.83 * * * \\
(24.89)\end{array}$ & $\begin{array}{l}-16.35 \\
(15.10) \\
\end{array}$ & $\begin{array}{c}-64.40 * * * \\
(19.71)\end{array}$ \\
\hline \multirow{3}{*}{$\begin{array}{c}\text { 2SLS Estimation } \\
\text { with Wealth Score- } \\
\text { ologit First Stage }\end{array}$} & Transport & $\begin{array}{c}1.401 \\
(2.925)\end{array}$ & $\begin{array}{l}-17.41 \\
(12.37)\end{array}$ & $\begin{array}{c}93.99 * * * \\
(18.37)\end{array}$ & $\begin{array}{c}43.93 * * * \\
(15.83)\end{array}$ & $\begin{array}{l}-6.217 \\
(20.12)\end{array}$ & $\begin{array}{c}62.72 * * * \\
(21.95)\end{array}$ & $\begin{array}{l}-15.45 \\
(10.98)\end{array}$ & $\begin{array}{c}-77.68 * * * \\
(15.42)\end{array}$ \\
\hline & Leisure & $\begin{array}{c}4.076^{* *} \\
(1.781)\end{array}$ & $\begin{array}{c}0.953 \\
(7.007)\end{array}$ & $\begin{array}{c}100.6^{* * * *} \\
(13.20)\end{array}$ & $\begin{array}{c}3.061 \\
(8.146)\end{array}$ & $\begin{array}{c}38.01 * * \\
(19.14)\end{array}$ & $\begin{array}{c}4.405 \\
(10.76)\end{array}$ & $\begin{array}{c}1.432 \\
(9.202)\end{array}$ & $\begin{array}{c}17.79 \\
(11.33)\end{array}$ \\
\hline & Total & $\begin{array}{c}5.478 \\
(3.552)\end{array}$ & $\begin{array}{l}-16.46 \\
(14.13)\end{array}$ & $\begin{array}{c}194.6^{* * * *} \\
(23.46)\end{array}$ & $\begin{array}{c}47.00 * * * \\
(18.04)\end{array}$ & $\begin{array}{c}31.79 \\
(31.38)\end{array}$ & $\begin{array}{c}67.13 * * * \\
(24.88)\end{array}$ & $\begin{array}{l}-14.02 \\
(15.28)\end{array}$ & $\begin{array}{c}-59.89 * * * \\
(19.89)\end{array}$ \\
\hline
\end{tabular}

Table 8 shows the output from running 2SLS regressions on the physical activity variables, using as an instrument the education fitted values from a first stage ran with an ordered logit, instead of an OLS model. Additionally, the bottom panel shows the results when the wealth score is included. Notice that the size of the education coefficients is now smaller in all six regressions. Furthermore, in the total physical activity models, this parameter is close to being relevant at the $10 \%$ level, while the one in the leisure estimation is still significant at the 5\% level. Conversely, the education parameter in the transport model is not significant and is now positive. It is worth remembering that this parameter has swapped signs

\footnotetext{
31 The nonlinear first stage of education is estimated against the interacted dummy variable, which acts as the instrument, the exposition dummy variable, the same covariates as previous estimations and the fixed effects for year of birth and municipality. Nonetheless, when using the ologit fitted values for education as the instrument, we include the covariates and the fixed effects, but not the dummy variables. The interacted dummy was already used as the source of exogenous variation when finding the fitted values from the ologit first stage, while the exposition dummy was included as part of that strategy, since in essence that first stage resembled a diff-in-diff model. Hence, the inclusion of those variables in the 2SLS model that uses the ologit fitted values is not necessary. It must be noted that when including the exposition dummy variable, the education coefficient lost its significance in the 2 SLS model.
} 
throughout the physical activity estimations, and is, generally speaking, non-significant. Thus, this new change does not come as a surprise.

Table 9 2SLS Estimations using an ologit First Stage- Consumption Habits

\begin{tabular}{|c|c|c|c|c|c|c|c|c|c|}
\hline & \multirow{2}{*}{ Education } & \multirow{2}{*}{\multicolumn{2}{|c|}{ Wealth ScoreSex $($ Male $=1)$}} & \multicolumn{3}{|c|}{ Social Security Regime } & \multicolumn{2}{|c|}{ Occupation } & \multirow{2}{*}{$\begin{array}{l}\text { Ownership } \\
\text { Refrigerator }\end{array}$} \\
\hline & & & & Subsidized & Special & Not Affiliatec & Unemployed & Inactive & \\
\hline $\begin{array}{l}\text { 2SLS Estimation- ologit First } \\
\text { Stage }\end{array}$ & $\begin{array}{r}0.123 * * * \\
(0.0262) \\
\end{array}$ & & $\begin{array}{l}-0.0917 \\
(0.193) \\
\end{array}$ & $\begin{array}{l}-0.154 \\
(0.153) \\
\end{array}$ & $\begin{array}{r}-0.0322 \\
(0.303) \\
\end{array}$ & $\begin{array}{l}-0.235 \\
(0.220) \\
\end{array}$ & $\begin{array}{l}-0.624 * \\
(0.359) \\
\end{array}$ & $\begin{array}{c}0.199 \\
(0.126) \\
\end{array}$ & $\begin{array}{c}0.481 * * * \\
(0.164) \\
\end{array}$ \\
\hline $\begin{array}{l}\text { 2SLS Estimation with Wealth } \\
\text { Score- ologit First Stage }\end{array}$ & $\begin{array}{c}(0.108 * * * \\
(0.0281)\end{array}$ & $\begin{array}{c}0.311^{* * *} \\
(0.109)\end{array}$ & $\begin{array}{l}-0.120 \\
(0.190)\end{array}$ & $\begin{array}{l}-0.107 \\
(0.148)\end{array}$ & $\begin{array}{l}-0.0415 \\
(0.302)\end{array}$ & $\begin{array}{l}-0.248 \\
(0.218)\end{array}$ & $\begin{array}{l}-0.630 * \\
(0.361)\end{array}$ & $\begin{array}{c}0.126 \\
(0.125)\end{array}$ & $\begin{array}{l}0.308^{*} \\
(0.168)\end{array}$ \\
\hline
\end{tabular}

Focusing on the consumption side, Table 9 presents the same analysis for the number of servings of fruits and vegetables consumed each day. Under this approach, the education coefficient gains magnitude and relevance. Now, an extra year of schooling impacts consumption of fruits and vegetables in at least 0.1 additional servings per day. Likewise, the wealth score parameter is highly relevant, though a bit smaller: the marginal impact of an increase in the index is 0.3 additional servings per day. When we include the wealth index, the importance of the education coefficient falls. Interestingly enough, the opposite is true for the physical activity analyses.

These results reinforce the hypothesis that SES has a meaningful effect on the prevalence of healthy choices, but the channels through which this happens differ between behaviors. Despite the fact that, in general terms, higher socioeconomic status seems to impact positively health-related choices, we can identify two pathways that make this so. On the one hand, more educated people tend to perform more physical activity in their leisure hours, while the contrary is true for physical activity done for transport reasons. On the other hand, those with higher education levels tend to consume more fruits and vegetables every day, though the effect is not very robust. Conversely, the wealth indicator is much larger and statistically relevant than that of the education variable in the consumption models. What is more, when it is included, it takes ground from the education variable in the latter, yet the opposite happens in the physical activity regressions.

Having tested the robustness of our results, and finding that, in general terms, it seems there is a pattern that supports our initial hypothesis, we now turn our attention to exploring whether the assumptions made in order to talk about causality hold.

\section{Testing the Assumptions}

Two assumptions were made if we wanted to talk about causal links. The first one concerns the relevance of the instrument: under this assumption, it is necessary that in the first stage the instrument is statistically significant in explaining changes in the endogenous variable. The second assumption, known 
as the exclusion restriction, requires that the instrument is not related to the unobserved factors that help explain changes in the variables of interest. In this context, this section presents four different tests: the first one aims to show that there is, in fact, relevance, while the other three check the exclusion restriction.

\section{a. Testing the Relevance of the Instrument}

The first step to determine if an instrument is relevant or not is through the results of the first stage. Table 10 presents the results of running the first stage, i.e. taking education as the dependent variable and running it against the dummy variables that capture the decree, the covariates, and year of birth and municipality fixed effects. Both the temporal exposure dummy (not shown here) and the dummy derived from the education of the mother present negative and significant coefficients. This makes sense because the latter is constructed based on the mother's level of education- less educated mothers mean having more probability of being exposed to the effects of the law. Therefore, the interaction between the temporal exposure dummy and the dummy that proxies exposition through the mother's education has a positive and statistically relevant coefficient: having a less educated mother and being born after 1971 is associated with 1.54 additional years of schooling. Thus, we can conclude that our instrument works well as far as relevance is concerned. Furthermore, the marginal effect of the decree is quite important: it is telling us that, on average, the exposed population has almost two additional years of schooling. For future research, it could be important to assess how this change in regulation was so effective in achieving its goals.

Table 10 OLS First stage: Education explained by the Decree 088 of 1976-Physical Activity Subsample

\begin{tabular}{|c|c|c|c|c|c|c|c|c|}
\hline & \multicolumn{5}{|c|}{ Instrument } & \multicolumn{3}{|c|}{ Education of the mother } \\
\hline & Interacted Dummy & Interacted Dummy & Interacted Dummy 2 & 2 Interacted Dummy 3 & 3 Exposition Dummy & None & Primary & Secondary \\
\hline Education & $\begin{array}{c}1.545^{* * * *} \\
(0.212) \\
\end{array}$ & & & & $\begin{array}{c}-6.097 * * * \\
(0.191) \\
\end{array}$ & & & \\
\hline Education & & $\begin{array}{l}2.328 * * \\
(1.018) \\
42.79 * *\end{array}$ & $\begin{array}{c}1.209 * * * \\
(0.250) \\
21.73 * * *\end{array}$ & $\begin{array}{c}0.945^{* * *} \\
(0.205) \\
23.98^{* * *}\end{array}$ & & $\begin{array}{c}-10.77 * * * \\
(0.676) \\
-203.6 * * *\end{array}$ & $\begin{array}{c}-9.017 * * * \\
(0.217) \\
-174.0^{* * *}\end{array}$ & $\begin{array}{c}-4.614 * * * \\
(0.181) \\
-114.1 * * *\end{array}$ \\
\hline Square Education & & (18.94) & $(5.492)$ & $(4.999)$ & & (12.54) & $(4.812)$ & $(4.365)$ \\
\hline
\end{tabular}

Using three different dummy variables as instruments (bottom panel) yield significant and robust results. First, note that the three of them have positive signs, and are significant at the $1 \%$ level. Additionally, the exposure variables, proxied with the level of education of the mother have negative signs and are also significant at the $1 \%$ level.

In a similar fashion, Table 11 describes the results for the first stages of the 2SLS models in the results chapter for the consumption habits models. Similar to what was found using the physical activity subsample, the decree is relevant in explaining the educational attainment of our sample's individuals. In fact, the magnitude of the coefficients of both the interacted dummy and the exposition dummy are similar to those presented in Table 10. 
Table 11 OLS First Stage: Education explained by the Decree 088 of 1976-Consumption Subsample

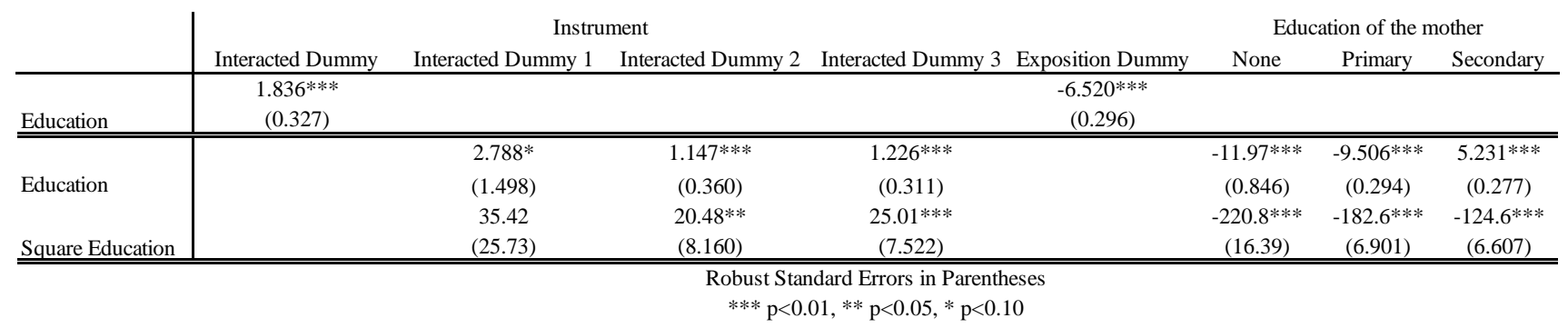

When overidentifying the system, we find that all three instruments are positive and relevant, while two out of the three instruments are still relevant in the first stage on the quadratic form of years of education. In addition, we find that the dummies for the mother's level of studies are all negative and significant in both regressions. Following this train of thought, we find that the instruments are adequate for our purposes since at least two of the instruments are relevant.

Now, the first stage is straightforward in showing whether this assumption holds or not. At first glance, if there is high significance, then one can rest assured there is relevance. Nevertheless, following Stock and Yogo (2002), it is desirable to have not only relevance but strength. Having an instrument that only marginally explains changes in the endogenous variable might increase the bias. Indeed, 2SLS estimators tend to yield biased (though consistent) results, unless a large sample is being used. This bias is intensified when too many instruments are included, or when the chosen instruments are weak (Angrist and Pischke, 2013). To ensure that this is not the case, several alternatives have been suggested. The simplest one comes from Staiger and Stock (1997), who propose as a rule of thumb that a first stage with an F-statistic smaller than ten is an indicator of a weak instrument. Thereupon, Stock and Yogo (2002) devised a similar method to identify weak instruments. Under their premise, the first stage F-statistic is compared to a critical value that takes into account the number of instruments and endogenous variables, and the size of relative bias or distortion the researcher is willing to tolerate. Accordingly, Table 12 and Table 13 present the different statistics calculated for each of the first stages of the results section, along with the number of instruments and endogenous variables. These values can be compared either to the F-statistic of 10 or to the critical values in the table on Stock and Yogo (2002).

In the case of the physical activity models, it is safe to say the instruments behave well in terms of strength. However, note that in the models that include the square form of years of education the F-statistic for this variable is below the 10-value threshold, though not too far below. This hints that the set of dummy variables do not work so well with this particular specification. Nonetheless, taken together, they do work well. Compared to the critical values set on Stock and Yogo (2002), we reject the null hypothesis when allowing a maximal size of 0.15 (at the most). 
Table 12 First stage Statistics to identify weak instruments- Physical Activity

\begin{tabular}{|c|c|c|c|c|c|c|c|c|}
\hline & Wealth Score & $\begin{array}{c}\text { Square Years } \\
\text { of Education }\end{array}$ & Ologit & $\begin{array}{l}\text { Number of } \\
\text { Instruments }\end{array}$ & $\begin{array}{c}\text { Number of } \\
\text { Endogenous } \\
\text { variables }\end{array}$ & F-statistic & $\begin{array}{l}\text { Cragg- Donald } \\
\text { Wald F Stat }\end{array}$ & $\begin{array}{l}\text { Kleibergen- } \\
\text { Paap Wald F } \\
\text { Stat }\end{array}$ \\
\hline Education & & & & 1 & 1 & 53.9 & 61.3 & 53.9 \\
\hline Education & $\mathrm{x}$ & & & 1 & 1 & 61.7 & 72.0 & 61.7 \\
\hline Education & & $\mathrm{x}$ & & 3 & 2 & 10.0 & & \\
\hline Square Education & & $\mathrm{x}$ & & 3 & 2 & 8.3 & & \\
\hline Both & & $\mathrm{x}$ & & 3 & 2 & & 17.9 & 9.3 \\
\hline Education & $\mathrm{x}$ & $\mathrm{x}$ & & 3 & 2 & 11.6 & & \\
\hline Square Education & $\mathrm{x}$ & $\mathrm{x}$ & & 3 & 2 & 9.4 & & \\
\hline Both & $\mathrm{x}$ & $\mathrm{x}$ & & 3 & 2 & & 20.3 & 8.8 \\
\hline Education & & & $\mathrm{x}$ & 1 & 1 & $2,080.0$ & $2,592.0$ & $2,080.0$ \\
\hline Education & $\mathrm{x}$ & & $\mathrm{x}$ & 1 & 1 & $1,830.0$ & $2,357.0$ & $1,830.0$ \\
\hline
\end{tabular}

The statistics of the first stage using the consumption habits variables are not fundamentally different from those found in the physical activity analysis. However, the strength of the three dummy variables when including the quadratic term of years of education is smaller than what was found previously. In this case, we cannot claim with certainty that these are strong instruments.

Table 13 First stage statistics to identify weak instruments- Consumption habits

\begin{tabular}{c|ccccc|rrr} 
& Wealth Score & $\begin{array}{c}\text { Square Years } \\
\text { of Education }\end{array}$ & Ologit & $\begin{array}{c}\text { Number of } \\
\text { Instruments }\end{array}$ & $\begin{array}{c}\text { Number of } \\
\text { Endogenous } \\
\text { variables }\end{array}$ & F-statistic & $\begin{array}{c}\text { Cragg- Donald } \\
\text { Wald F Stat }\end{array}$ & $\begin{array}{c}\text { Kleibergen- } \\
\text { Paap Wald F } \\
\text { Stat }\end{array}$ \\
\hline Education & & & & 1 & 1 & 28.8 & 31.5 & 28.8 \\
Education & $\mathrm{x}$ & & & 1 & 1 & 30.5 & 33.9 & 30.5 \\
Education & & $\mathrm{x}$ & & 3 & 2 & 5.9 & & \\
Square Education & & $\mathrm{x}$ & & 3 & 2 & 3.7 & & \\
Both & & $\mathrm{x}$ & & 3 & 2 & 0.8 & 1.4 & 0.8 \\
Education & $\mathrm{x}$ & $\mathrm{x}$ & & 3 & 2 & 6.4 & & \\
Square Education & $\mathrm{x}$ & $\mathrm{x}$ & & 3 & 2 & 4.0 & & \\
Both & $\mathrm{x}$ & $\mathrm{x}$ & & 3 & 2 & 0.7 & 1.4 & 0.7 \\
Education & & & $\mathrm{x}$ & 1 & 1 & 796.1 & 985.2 & 796.1 \\
Education & $\mathrm{x}$ & & $\mathrm{x}$ & 1 & 1 & 702.8 & 882.0 & 702.8
\end{tabular}

\section{b. Testing the Exclusion Restriction}

We devised ways that might signal whether we are close to meeting the exclusion restriction. Since our identification strategy is essentially a differences-in-differences model, testing the exclusion restriction is equivalent to judging if the parallel trend condition is present. To this end, we devised three ways of gauging this. The first one revolves around evaluating graphically if the level of education between exposition groups varied in a similar way before the introduction of the Decree. Though it is not a formal statistical test, the graphical assessment sheds light on whether we are on the right track. The second test takes a different temporal exposition dummy variable than the one initially used. The idea is to establish a year of birth threshold so that the instrument no longer has any effect over the variables of interest. The final test runs the OLS models of the dependent variables against education, the fixed effects, and the covariates, to see if there are unobserved characteristics in the residuals that are significantly correlated with the instruments. 


\section{i. Graphical Evaluation}

Figure 6 Parallel trends: Education

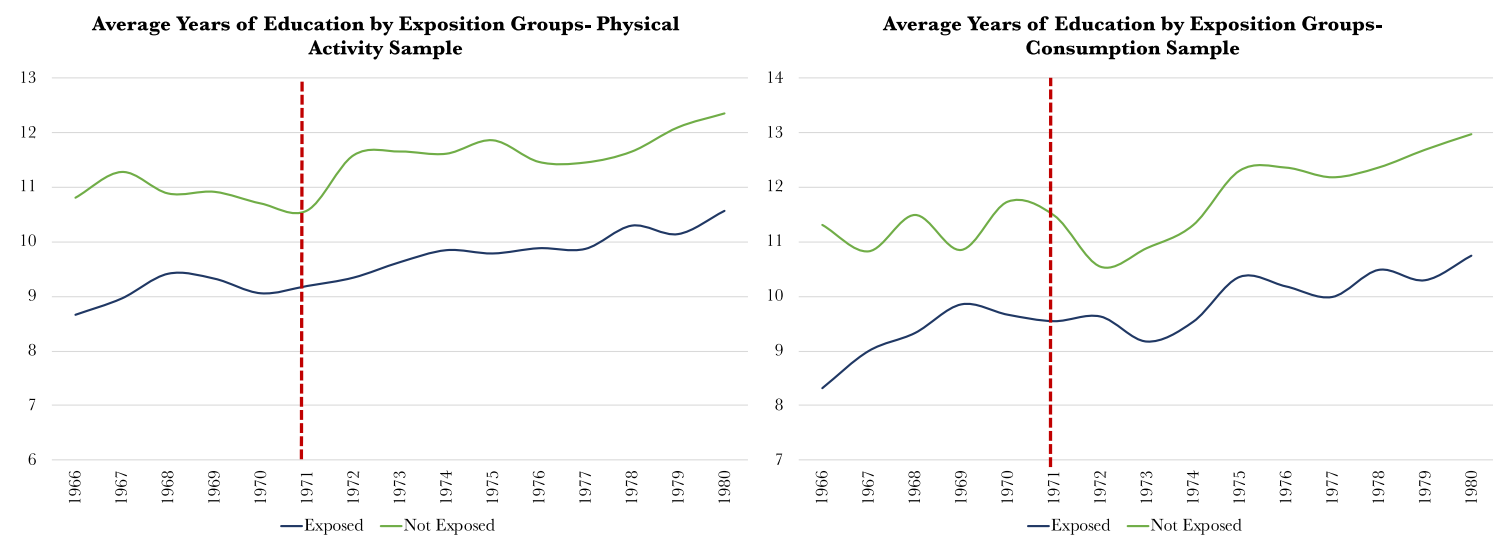

Figure 6 shows the average number of years of education as a function of the birth year. We use the predicted values from running the first stage since it is more plausible that the parallel trend assumption holds conditional on the covariates.

A good indicator of the presence of parallel trends is that both series of average years of education do not look like they are about to cross, or that conversely are going in opposite directions. From the Figure above, though the lines do not move in perfect consonance, at least they do seem to follow the same path right before the threshold birth year. As mentioned before, this is not a formal test. Instead, it serves to point whether there is a chance that the parallel trend assumption does not hold in this context. As things stand, we do believe this is a positive signal for the presence of the exclusion restriction ${ }^{32}$. Appendix A displays several difference-of-means and proportions tests as a function of the exposition group (Table 19 - Appendix A). All yield significant results, which is why we included them in the regression analyses. Additionally, we find that the correlation coefficient between both series is highest in the years preceding 1971, further supporting the notion that the parallel trend assumption holds (Table 20-Appendix A).

\section{ii. Placebo Test}

We devised a placebo test to assess if the effects found in the previous two sections are the product of the decree and not just a "statistical coincidence." Essentially, we change the temporal exposition dummy to a year in which the effects of the law should not yet appear, or at least be very small. However, if we want the test to be believable, we cannot move too far back in time. With this in mind, we establish this fake time dummy in the year 1968. Those born after that year are part of the "exposed" group. We chose

\footnotetext{
${ }^{32}$ We also plot the wealth score and other control variables by exposition group (Appendix A), since it is important that the parallel trend assumption is also present in other variables for the fixed effects to effectively control for unobserved characteristics. Remember that the main assumption that makes this so is that those unobserved characteristics do not vary much in time. From what is seen in Appendix A we believe this is the case.
} 
that particular year since it is eight years before the implementation of the decree, which means that those born around that year were already past the time of entry to primary school. Following that train of thought, by that age, the decision of entering primary school would have already been made. Besides, we cropped out from our sample the individuals born after 1971, to work with the subsample that should not have been impacted by the regulatory change in question.

In a broader context, we display the results of the short regressions, using as the instrument the interaction between the exposition variable and the new temporal threshold dummy. This as a consequence that there should not be any significant effects on our variables of interest. Similarly, there should not be any significance in the first stage, since the Decree aimed at increasing the population's level of education.

The right panel on Table 14 shows the results of running the short regressions using a placebo instrument, in the case of the linear form of education. In turn, the left panel on this same table does the same for the case we overidentify the system with three instruments. Note how none of the instruments in any of the regressions are relevant, which is precisely what is expected when the parallel trend assumption is present. Indeed, those born after 1968 until 1970 were too old to have been affected by the implementation of the decree in 1976.

Table 14 Short Regression using an alternate time dummy- Physical Activity

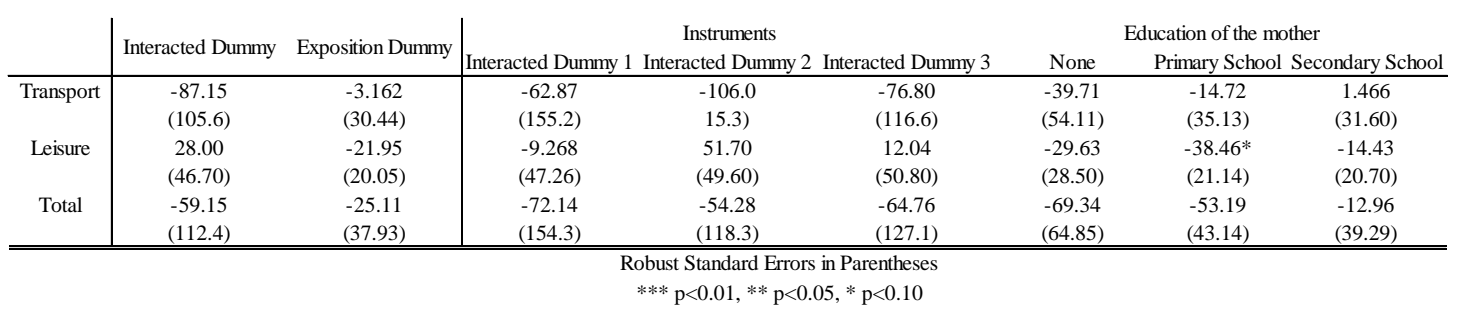

Table 15 Short Regression using an alternate time dummy - Consumption Habits

\begin{tabular}{l|cccccccc} 
& Interacted Dummy & Exposition Dummy & Interacted Dummy 1 & Interacted Dummy 2 & Interacted Dummy 3 & $\begin{array}{c}\text { Education of the Mother } \\
\text { Primary School Secondary School }\end{array}$ \\
\hline \multirow{2}{*}{ Fruit and Vegetables } & 0.289 & -0.553 & -1.160 & -0.320 & 0.607 & -0.672 & -0.637 \\
& $(0.838)$ & $(0.381)$ & $(1.304)$ & $(0.941)$ & $(0.892)$ & $(0.697)$ & $(0.446)$ & $(0.418)$ \\
\hline \hline
\end{tabular}

This last table does the same as Table 14 but for the consumption habits variable. Likewise, it shows the alternative instrument variable has no effect on the number of servings per day of fruits and vegetables, which is in line with what is expected when there are parallel trends.

\section{iii. Significance of the instruments against the error term}

This third (and final) test, is designed to see if the instruments hold a relevant correlation with the unobserved characteristics present in the error term after running an OLS regression of the dependent variables against our variable of interest (education), the covariates and the set of fixed effects. 
Table 16 Results of running OLS models of the residuals vs. the instruments- Physical Activity

\begin{tabular}{c|cccc} 
& Interacted Dummy & Interacted Dummy 1 & Interacted Dummy 2 & Interacted Dummy 3 \\
\hline Leisure & 1.625 & 27.1633 & 8.7375 & -2.8587 \\
& $(6.1131)$ & $(36.062)$ & $(10.2591)$ & $(6.6458)$ \\
Transport & 5.157 & -36.7189 & 0.5083 & 9.5319 \\
& $(10.4296)$ & $(50.4719)$ & $(14.6550)$ & $(12.1059)$ \\
Total & 6.7829 & -9.555 & 9.2459 & 6.6731 \\
& $(12.396)$ & $(67.1682)$ & $(18.2028)$ & $(14.18509)$ \\
\hline \hline \multicolumn{4}{c}{} \\
& Robust Standard Errors in Parentheses \\
& $* * * 0.01, * * \mathrm{p}<0.05, * \mathrm{p}<0.10$
\end{tabular}

Table 16 describes the coefficients from the instruments and their standard errors, in an OLS framework, in which the dependent variables are the residuals from running a regression of the physical activity variables against education, the control variables and the set of fixed effects. It is easily seen there is no significance in these regressions. This shows that our instruments work well in terms of exogeneity. Table 17 Results of running OLS models of the residuals vs. the instruments- Consumption habits

\begin{tabular}{c|cccc} 
& Interacted Dummy & Interacted Dummy 1 & Interacted Dummy 2 & Interacted Dummy 3 \\
\hline Fruits and Vegetables & -0.00308 & -0.1099 & 0.05810 & -0.021547 \\
& $(0.09257)$ & $(0.4269)$ & $(0.14372)$ & $(0.1008)$ \\
\hline \hline \multicolumn{4}{c}{ Robust Standard Errors in Parentheses } \\
& $* * * \mathrm{p}<0.01, * * \mathrm{p}<0.05, * \mathrm{p}<0.10$
\end{tabular}

In a similar fashion, Table 17 displays the same results of Table 16, but for the consumption habits model. Again, notice how none of the coefficients are relevant under any level of significance.

In sum, the tests presented in this section signal two things: first, the instruments seem to work well in terms of relevance, though the transport estimation must be interpreted with caution. The second one is that there are reasons to believe the instruments meet the exclusion restriction since the three tests presented here do not suggest otherwise.

\section{iv. Limitations}

The most noteworthy limitation of our results is that we can only talk about causality at the local level. Indeed, we work under the assumption that the decree affected the decisions of a particular populationthe compliers- on which our conclusions are valid. Beyond them, it is possible our results do not hold, at least not without bias. One thing that could pose as a limitation of this work is that we do not study the mechanisms through which education acts in health-related decisions. On this point we must note that, other than studying the socioeconomic channels, the unobserved ones are beyond the scope of this investigation. We do highlight, however, the importance of studying them in future research, for it might be more cost effective to tackle these channels, rather than aiming to increase the population's general level of education with the purpose of fostering healthy choices.

On the other hand, we find the limitations posed by the data. It seems people are not very good at measuring the amount of physical activity they perform in the past week, or the amount of food consumed 
in the past month or so. This is particularly true for consumption habits: people can either overestimate or underestimate the grams of fruits or vegetables in a serving. To know the direction in which this potential bias works, however, is impossible for us to determine with certainty. This is not such a grave matter in the physical activity analysis, due to how the questions are posed. Lastly, a limitation that was consistently identified throughout the literature was the lack of longitudinal data. It seems that, regardless the level of developing a country has, it is rather uncommon this type of data is present. The availability of this information would be very useful when seeking to establish causality.

\section{Concluding Remarks and Discussion}

Through the use of the Encuesta Nacional de Situación Nutricional- ENSIN (2010), and the Encuesta Nacional de Demografía y Salud - ENDS (2010), we sought to establish the effects of higher educational attainment on the amount of weekly physical activity and daily intake of fruits and vegetables in Colombia. The presence of unobserved characteristics, such as motivation, time preferences, and self-efficacy, which are highly correlated with both educational attainment and health-related behaviors derive in an Omitted Variable Bias. Consequently, we devised an empirical strategy that aimed at correcting this bias to establish causal links between education and the dependent variables. First, we included municipality and year of birth fixed effects, as well as several covariates. Second, we used the Decree 088 of 1976 as a source of exogenous variation in a 2SLS framework. The decree's goal was to increase the general population's level of education by making primary school compulsory for children of age 5 or 6 , and by adding four years of middle school to the concept of basic education. We use this to our advantage, by exploiting the change in education decisions for people who were 6 years or younger in the year the decree came into effect. To the best of our knowledge, this particular source of exogeneity has not been used in similar studies in Colombia before, which constitutes one of the prime contributions of this article.

Our results point to a positive and robust impact of greater socioeconomic status- proxied with education- and the presence of health-related behaviors. This is particularly true for the physical activity that is done for leisure, where the marginal effect of education is around 10 additional minutes of exercise per week. In the case of the transport-motivated physical activity, the education parameters were far from being significant in the main 2SLS models and sometimes presented a negative sign. We found that for the consumption patterns, access plays a fundamental role. When including the wealth score, we found that this variable had a superior impact on consumption habits, and even had a positive effect on the magnitude of the education coefficient. This means that, before an individual can effectively make the choice of having healthy eating habits, he/she must first have the opportunity to access this type of food. We must note that the analysis presented here on nutrition habits is quite novel in Colombia. Indeed, the 
way we studied consumption patterns, seeking to establish causal explanations, and obtaining results that to the best of our knowledge have not been replicated in the country opens new windows for future research. In other words, this part of the investigation sets the grounds for more profound inquiries on this particular behavior.

Now, we do not read these results in the void. The inclusion of social security and ownership variables helps us makes sense of the story the data are trying to tell us. In the physical activity models, we get that, when the exercise is done for transport reasons, then being part of the subsidized regime (or not being affiliated at all) is positively related to the dependent variable. Conversely, these two dummy variables are non-significant in the leisure exercise, while the special regime one is positive and statistically relevant. In the consumption habits models, being part of the subsidized regime or not being affiliated to the social security system negatively impacts this variable, relative to those in the contributive regime. These results further support the idea that the channels through which SES impacts a healthy living are different as a function of the behaviors we analyze.

Can we say anything about the presence of protective factors in low SES individuals? We believe the answer is yes. The lack of a significant effect of education on the physical activity done for transport reasons signals that low SES individuals tend to perform more often than not this type of activity than the wealthier, more educated, individuals. This can be because these individuals use means of transportation that require them to be more physically active. The control variables' coefficients support this: people from the subsidized regime or that are not affiliated perform more physical activity for transport motives than the individuals in the contributive regime. Similarly, owning a car or a motorcycle is negatively associated with this behavior, which is not the case for the leisure component. Additionally, these same covariates, along with the occupation dummies and the wealth score, help us capture other factors that might work through the educational attainment, such as time availability (in the case of the physical activity analysis $)^{33}$.

\section{Policy recommendations}

Remember the final end of this research is to find credible results that might be used in policy recommendations. When we combine our findings with those of previous articles, the fundamental recommendation is that a one-size-fits-all approach is doomed to fail. Authors have found that the relationship between education and health behaviors is not monotonic. Combine that with our results about

\footnotetext{
${ }^{33}$ On the one hand, more educated- wealthier- individuals may have more free time to undertake leisure activities, including exercise. On the other hand, worse-off individuals may require commuting longer distances, many times using the bicycle or walking as part of the transport means. Without incorporating the covariates and the wealth score in the models, the effect of this particular channel could have been reflected through the education coefficient.
} 
the differences in the impact of educational attainment on the types of physical activity, and on nutrition patterns, and you obtain that any policy in this front must consider the level of education, and overall SES, of each specific population. Consider, for example, that education alters the cognitive abilities of individuals. Furthermore, concerning the benefits of having good health habits the information is readily available, so it is possible that a policy that spreads information about health-related behaviors might only be effective in the most educated people, deepening inequalities. In addition, future policies must take into consideration that there are protective factors that might help foster healthy habits in the most vulnerable population in a more effective (efficient) way.

With this in mind, the most straightforward approach must consider that more educated people tend to perform more leisure physical activity, while the less educated perform more transport-related exercise. Consequently, a policy- or several- could foster the behavior which will most easily be undertaken by individuals with certain socioeconomic background. For instance, a good tactic might be to diffuse information about physical activity in key sites, to promote leisure physical activity, while also encouraging the use of alternate- more physically demanding- means of transport. That way, the target population will receive the message the suits best their life setting. Nonetheless, it is also desirable to have both behaviors present in the general population. That is, we would also like for low SES individuals to partake in leisure physical activities, while also having higher SES people commuting in a more active way. In this front, more general approaches come to mind. On the one hand, policies that free up time in the lower SES segment of the population are desirable, since it constitutes the first step towards fostering leisure exercise. Conversely, policies that make more attractive for the wealthier to walk or use the bicycle as a means of transport are also important when trying to achieve better health-habits. From our results on the impact of SES on consumption habits, it is key to provide access to healthy food. To make it readily available, and even more so than unhealthy- highly caloric- options must be at the center of any policy that wants to enhance the nutrition patterns of its target population.

All in all, we find that Colombia is in a unique position in the epidemiological transition where it presents patterns seen in more advanced economies, while some of its population still has behaviors observed in lower income countries. This leaves a small window of opportunity to act, before we reach a complex health scenario in which it might be more difficult to both prevent and cure certain diseases. 


\section{References}

Adler, N. E., \& Newman, K. (2002). Socioeconomic Disparities In Health: Pathways And Policies. Health Affairs, 21(2), 60-76. doi:10.1377/hlthaff.21.2.60

Angrist, J. D., \& Krueger, A. B. (2001). Instrumental Variables and the Search for Identification: From Supply and Demand to Natural Experiments. Journal of Economic Perspectives, 15(4), 69-85.

Angrist, J. D., \& Pischke, J. (2013). Mostly harmless econometrics: An empiricists companion. United States: Content Technologies.

Barbeau, E. M; Krieger, N \& Soobader, M. (2004). Working Class Matters: Socioeconomic Disadvantage, Race/Ethnicity, Gender, and Smoking in NHIS 2000. American Journal of Public Health, 94(2), 269-278. doi:10.2105/ajph.94.2.269

Berry, B. (2007). Disparities in Free Time Inactivity in the United States: Trends and Explanations. Sociological Perspectives, 50(2), 177-208. doi:10.1525/sop.2007.50.2.177

Brownson, R. C., Boehmer, T. K., \& Luke, D. A. (2005). Declining rates of physical activity in the united states: What Are the Contributors? Annual Review of Public Health, 26(1), 421-443. doi:10.1146/annurev.publhealth.26.021304.144437

Cawley, J., \& Ruhm, C. (2011). The Economics of Risky Health Behaviors. National Bureau of Economic Research. doi: $10.3386 /$ w17081

CDC, (n.d.) Cigarette Smoking-Attributable Mortality and Years of Potential Life Lost -- United States, 1990. Retrieved from https://www.cdc.gov/mmwr/preview/mmwrhtml/00021441.htm

Chang, V. W., \& Lauderdale, D. S. (2009). Fundamental Cause Theory, Technological Innovation, and Health Disparities: The Case of Cholesterol in the Era of Statins. Journal of Health and Social Behavior, 50(3), 245260. doi:10.1177/002214650905000301

Clark, D., \& Royer, H. (2010). The Effect of Education on Adult Health and Mortality: Evidence from Britain. National Bureau of Economic Research. doi:10.3386/w16013

Cutler, D., \& Lleras-Muney, A. (2006). Education and Health: Evaluating Theories and Evidence. National Bureau of Economic Research. doi:10.3386/w12352

Cutler, D. M., \& Lleras-Muney, A. (2010). Understanding differences in health behaviors by education. Journal of Health Economics, 29(1), 1-28. doi:10.1016/j.jhealeco.2009.10.003

Currie, J., \& Moretti, E. (2003). Mothers Education and the Intergenerational Transmission of Human Capital: Evidence from College Openings and Longitudinal Data. National Bureau of Economic Research. doi:10.3386/w9360

Davila, E., Quintero, M., Orrego, M., Ford, E., Walke, H., Arenas, M., \& Pratt, M. (2013). Prevalence and risk factors for metabolic syndrome in Medellin and surrounding municipalities, Colombia, 2008-2010. Preventive Medicine, 56(1), 30-34. doi:10.1016/j.ypmed.2012.10.027

Decreto 088. Ministerio de Educación Nacional, Bogotá, Colombia. January 22 of 1976

DeWalque, D. (2007). Does education affect smoking behaviors? Journal of Health Economics,26(5), 877-895. doi:10.1016/j.jhealeco.2006.12.005

DHS (2018). Guide to DHS Statistics. DHS-7 The Demographic and Health Survey. Retrived from: https://dhsprogram.com/Data/Guide-to-DHS-Statistics/index.cfm

Drewnowski, A. (2009). Obesity, diets and social inequalities. Nutrition Reviews, 67. Retrieved May 30, 2018, from https://www.ncbi.nlm.nih.gov/pubmed/19453676

Gakidou, E., Mallinger, L., Abbott-Klafter, J., Guerrero, R., Villalpando, S., Lopez Ridaura, R., Aekplakorn, W., Naghavi, M., Lim, S., Lozanoa, R., Murraya, C., (2011). Management of diabetes and associated cardiovascular risk factors in seven countries: a comparison of data from national health examination surveys. Bull. World Health Organ 89, 172-183.

Gaziano, T. A., \& Gaziano, J. M. (2018). Chapter 233: Epidemiology of Cardiovascular Disease. In Harrison's Principles of Internal Medicine (20th ed., Vol. 1). McGraw Hill Education. 
Giles-Corti, B., \& Donovan, R. J. (2002). Socioeconomic Status Differences in Recreational Physical Activity Levels and Real and Perceived Access to a Supportive Physical Environment. Preventive Medicine, 35(6), 601-611. doi:10.1006/pmed.2002.1115

Gómez, L. F., Duperly, J., Lucumí, D. I., Gámez, R., \& Venegas, A. S. (2005). Nivel de actividad física global en la población adulta de Bogotá (Colombia). Prevalencia y factores asociados. Gaceta Sanitaria, 19(3), 206-213. doi:10.1157/13075953

González, S; Sarmiento, O; Lozano, O;Ramírez, A \& Grijalba, C. (2014). Niveles de actividad física de la población colombiana: Desigualdades por sexo y condición socioeconómica. Biomédica, 34, 447-459. Retrieved May 30, 2018, from http://www.scielo.org.co/pdf/bio/v34n3/v34n3a14.pdf

Grimard, F., \& Parent, D. (2007). Education and smoking: Were Vietnam war draft avoiders also more likely to avoid smoking? Journal of Health Economics, 26(5), 896-926. doi:10.1016/j.jhealeco.2007.03.004

Hosseinpoor, A; Bergen, N; Kunst, A; Harper, S; Guthold, R; Rekve, D; Tursan d'Espaignet, E; Naidoo, N \& Chatterji, S. (2012). Socioeconomic inequality in the prevalence of non-communicable diseases in low-and middle-income countries: Results from the World Health Survey. BMC Public Health,12(1). doi:10.1186/14712458-12-474

Kearney, J. (2010). Food consumption trends and drivers. Philosophical Transactions of the Royal Society B: Biological Sciences, 365(1554), 2793-2807. doi:10.1098/rstb.2010.0149

Lanas, F., Avezum, A., Bautista, L.E., Diaz, R., Luna, M., Islam, S., Yusuf, S., INTERHEART Investigators in Latin America, (2007). Risk factors for acute myocardial infarction in Latin America: the INTERHEART Latin American study. Circulation 115, 1067-1074.

Layte, R., \& Whelan, C. T. (2008). Explaining Social Class Inequalities in Smoking: The Role of Education, SelfEfficacy, and Deprivation. European Sociological Review, 25(4), 399-410. doi:10.1093/esr/jcn022

Link, B. G., \& Phelan, J. (1995). Social Conditions As Fundamental Causes of Disease. Journal of Health and Social Behavior, 35, 80. doi:10.2307/2626958

Lynch, J., Kaplan, G., \& Salonen, J. (1997). Why do poor people behave poorly? Variation in adult health behaviours and psychosocial characteristics by stages of the socioeconomic lifecourse. Social Science \& Medicine, 44(6), 809-819. doi:10.1016/s0277-9536(96)00191-8

Mahmood, S. S; Levy, D; Vasan R.S \& Wang, T.J. (2014). The Framingham Heart Study and the epidemiology of cardiovascular disease: A historical perspective. The Lancet, 383(9921), 999-1008. doi:10.1016/s01406736(13)61752-3

McLaren, L. (2007). Socioeconomic Status and Obesity. Epidemiologic Reviews, 29(1), 29-48. doi:10.1093/epirev/mxm001

Miech, R; Pampel, F; Kim, J \& Rogers, R. (2011). The Enduring Association between Education and Mortality. American Sociological Review, 76(6), 913-934. doi:10.1177/0003122411411276

Miranda, S; Kinra, S; Casas, J.P; Smith, D \& Ebrahim, S. (2008). Non-communicable diseases in low and middleincome countries: Context, determinants and health policy (2008). Tropical Medicine and International Health, 13(10), 1225-1234. Retrieved May 30, 2018, from https://onlinelibrary.wiley.com/doi/abs/10.1111/j.1365-3156.2008.02116.x.

Monteiro, C. A; Moura E; Wolney C \& Popkin, B. (2004). Socioeconomic status and obesity in adult populations of developing countries: A review. Bulletin of the World Health Organization, 82(12).

Morris, J., Heady, J., Raffle, P., Roberts, C., \& Parks, J. (1953). Coronary Heart-Disease And Physical Activity Of Work. The Lancet, 262(6795), 1053-1057. doi:10.1016/s0140-6736(53)90665-5

Omran, A. R. (2005). The Epidemiologic Transition: A Theory of the Epidemiology of Population Change. Milbank Quarterly, 83(4), 731-757. doi:10.1111/j.1468-0009.2005.00398.x

Pampel, F. C., Krueger, P. M., \& Denney, J. T. (2010). Socioeconomic Disparities in Health Behaviors. Annual Review of Sociology, 36(1), 349-370. doi:10.1146/annurev.soc.012809.102529 
Pampel, F. C., \& Rogers, R. G. (2004). Socioeconomic Status, Smoking, and Health: A Test of Competing Theories of Cumulative Advantage. Journal of Health and Social Behavior, 45(3), 306-321. doi:10.1177/002214650404500305

Phelan, J. C., Link, B. G., Diez-Roux, A., Kawachi, I., \& Levin, B. (2004). "Fundamental Causes" of Social Inequalities in Mortality: A Test of the Theory. Journal of Health and Social Behavior, 45(3), 265285. https://doi.org/10.1177/002214650404500303

Powell, L. M; Slater, S; Chaloupka, F \& Harper, D. (2006). Availability of Physical Activity-Related Facilities and Neighborhood Demographic and Socioeconomic Characteristics: A National Study. American Journal of Public Health, 96(9), 1676-1680. doi:10.2105/ajph.2005.065573

Ramírez, M. T., \& Tellez, J. P. (2006.). La educación primaria y secundaria en Colombia en el siglo XX. Borradores De Economía, 379. Retrieved November, 2018, from http://www.banrep.gov.co/sites/default/files/publicaciones/pdfs/borra379.pdf

Reinhold, S., \& Jürges, H. (2009). Secondary School Fees and the Causal Effect of Schooling on Health Behavior. SSRN Electronic Journal. doi:10.2139/ssrn.1443946

Rosengren, A., \& Wilhelmsen, L. (1997). Physical activity protects against coronary death and deaths from all causes in middle-aged men. Evidence from a 20-year follow-up of the primary prevention study in Göteborg. Annals of Epidemiology, 7(1), 69-75. doi:https://doi.org/10.1016/S1047-2797(96)00106-8

Steiger, D., \& Stock, J. H. (1997). Instrumental Variables Regression with Weak Instruments. Econometrica, 65(3), 557-586. Retrieved from https://www.jstor.org/stable/2171753.

Stock, J. H., \& Yogo, M. (2002). Testing for Weak Instruments in Linear IV Regression. National Bureau of Economic Research. Retrieved from https://www.nber.org/papers/t0284.pdf.

Temneanu, O. R., Trandafir, L. M., \& Purcarea, M. R. (2016). Type 2 diabetes mellitus in children and adolescents: A relatively new clinical problem within pediatric practice. Journal of Medicine and Life, 9(3). Retrieved from https://www.ncbi.nlm.nih.gov/pmc/articles/PMC5154306/.

Vineis, P., Stringhini, S., \& Porta, M. (2014). The environmental roots of non-communicable diseases (NCDs) and the epigenetic impacts of globalization. Environmental Research, 133, 424-430. doi:10.1016/j.envres.2014.02.002

Warren, G. W., \& Cummings, K. M. (2013). Tobacco and Lung Cancer: Risks, Trends, and Outcomes in Patients with Cancer. American Society of Clinical Oncology Educational Book, 33, 359-364. doi:10.1200/edbook_am.2013.33.359

Wen, M. (2007). Walking for Transportation or Leisure: What Difference Does the Neighborhood Make? Journal of General Internal Medicine, 22(12), 1674-1680. doi:10.1007/s11606-007-0400-4

WHO (2016). Global Report on Diabetes (Rep.). Retrieved from http://apps.who.int/iris/bitstream/handle/10665/204871/9789241565257_eng.pdf;jsessionid=69394BB3CDFF 8B70A8FE12B750AC4161?sequence=1

WHO (n.d.) Healthy diet. Retrieved from http://www.who.int/news-room/fact-sheets/detail/healthy-diet

WHO (2015). Physical Activity and Adults. Retrieved from http://www.who.int/dietphysicalactivity/factsheet_adults/en/

WHO. (n.d.) Non communicable diseases. Retrieved from https://www.who.int/news-room/factsheets/detail/noncommunicable-diseases

Winkleby, M. A et al. (1992). Socioeconomic status and health: How education, income, and occupation contribute to risk factors for cardiovascular disease. American Journal of Public Health, 82(6), 816-820. doi:10.2105/ajph.82.6.816

World Bank. (n.d.) Indicators. Retrieved from https://data.worldbank.org/indicator?tab=all 


\section{Box 1: Surveys from the year 2010}

Box 1: ENSIN from the year 2010

When we first started this investigation, back in June 2018, the Ministry of Health and Social Protection had issued a report with the preliminary results from the survey conducted in the year 2015. Though the data from the ENDS from 2015 is available in the DHS program web page, when we contacted the Ministry, we were told the ENSIN database was yet to be fully consolidated and available to be used in statistical analyses beyond the ones did for the report. For this reason, we decided to work with the databases from the year 2010.

There are several implications from using data that were taken 8 years ago. Most importantly, it is possible that the patterns and results found here might have changed in that period of time. This as a consequence of the possible changes brought about by greater economic and social development. Nonetheless, we believe that the essence of what was found in this investigation- that greater socioeconomic status impacts positively health-related behaviors, and that there are protective factors for low SES individuals, such as the use of the bicycle as a means of transport- still hold in the present.

\section{Box 2: 2SLS Estimation for log-transformed physical activity variables}

Box 2: Physical activity models using the log-transformation of the dependent variables

We consider the possibility of the physical activity variables being highly skewed and with wide variance. We incorporate this by applying the logarithm transformation to the three variables used (transport, leisure and total physical activity), and run the main models from the results section.

Table 18 shows the results of running the same OLS and 2SLS models on Table 4, using as dependent variables the log-transformation of the original transport, leisure and total physical activity variables. Under this new specification, the significance does not vary importantly, and the direction and sizes of the effects are consistent with what was previously found. An additional year of schooling increases the level of physical activity done for leisure in $2.5 \%$ to $4.2 \%$ under the linear form of the education variable. Similarly, the level of transport and total physical activity increases in over $14 \%$ with an additional year of education. Lastly, the covariates' effects also present significance and direction in line with previous results. 
Table 18 OLS and 2SLS Results on the log-version of the Physical Activity Variables

\begin{tabular}{|c|c|c|c|c|c|c|c|c|c|}
\hline & & \multirow{2}{*}{ Education } & \multirow{2}{*}{ Education $^{2}$} & \multirow{2}{*}{ Sex $($ Male $=1)$} & \multicolumn{3}{|c|}{ Social Security Regime } & \multicolumn{2}{|c|}{ Ownership } \\
\hline & & & & & Subsidized & Special & Not Affiliated & Motorcycle & Vehicle \\
\hline \multirow{6}{*}{ OLS Estimation } & Transport & 0.00335 & & $0.446 * * *$ & $0.0944 * *$ & 0.0286 & $0.117 * *$ & $-0.122 * * *$ & -0.341 \\
\hline & & $(0.00429)$ & & $(0.0312)$ & $(0.0397)$ & $(0.0795)$ & $(0.0518)$ & $(0.0370)$ & $(0.0482)$ \\
\hline & Leisure & $0.0253 * *$ & & $0.353 * * *$ & -0.0110 & 0.141 & 0.0113 & 0.0558 & 0.0241 \\
\hline & & $(0.00619)$ & & $(0.0440)$ & $(0.0562)$ & $(0.104)$ & $(0.0775)$ & $(0.0527)$ & $(0.0664)$ \\
\hline & Total & $0.0182 * * *$ & & $0.504 * * *$ & $0.0886^{* *}$ & 0.0642 & $0.122 * *$ & $-0.0975 * * *$ & $-0.223 * * *$ \\
\hline & & $(0.00418)$ & & $(0.0303)$ & $(0.0387)$ & $(0.0801)$ & $(0.0504)$ & $(0.0370)$ & $(0.0475)$ \\
\hline \multirow{6}{*}{$\begin{array}{l}\text { OLS Estimation } \\
\text { with Education }\end{array}$} & Transport & $0.0489 * * *$ & $-0.00245^{* * *}$ & $0.448 * * *$ & $0.0954 * *$ & 0.0447 & $0.115^{* *}$ & $-0.129 * * *$ & $-0.322 * * *$ \\
\hline & & $(0.0153)$ & $(0.000790)$ & $(0.0312)$ & $(0.0397)$ & $(0.0799)$ & $(0.0518)$ & $(0.0371)$ & $(0.0486)$ \\
\hline & Leisure & $0.0395^{*}$ & -0.000739 & $0.353 * * *$ & -0.0103 & 0.144 & 0.0110 & 0.0541 & 0.0299 \\
\hline & & $(0.0234)$ & $(0.00120)$ & $(0.0440)$ & $(0.0562)$ & $(0.104)$ & $(0.0755)$ & $(0.0529)$ & $(0.0669)$ \\
\hline & Total & $0.0486 * * *$ & $-0.00163 * *$ & $0.505 * * *$ & $0.0892 * *$ & 0.0743 & $0.120 * *$ & $-0.101 * * *$ & $-0.210 * * *$ \\
\hline & & $(0.0147)$ & $(0.000768)$ & $(0.0303)$ & $(0.0388)$ & $(0.0806)$ & $(0.0504)$ & $(0.0370)$ & $(0.0479)$ \\
\hline \multirow{6}{*}{ 2SLS Estimation } & Transport & $0.147 * *$ & & 0.175 & $0.367 * * *$ & -0.121 & $0.332 * * *$ & -0.0808 & $-0.521 * * *$ \\
\hline & & $(0.0734)$ & & (0.109) & $(0.133)$ & $(0.133)$ & $(0.111)$ & $(0.0559)$ & $(0.105)$ \\
\hline & Leisure & 0.0418 & & $0.453^{* *}$ & 0.0274 & -0.0133 & 0.00146 & 0.0292 & -0.00853 \\
\hline & & $(0.147)$ & & $(0.201)$ & $(0.340)$ & $(0.140)$ & $(0.223)$ & $(0.0764)$ & $(0.182)$ \\
\hline & Total & $0.145^{* *}$ & & $0.362 * * *$ & $0.343^{* *}$ & -0.0912 & $0.312 * * *$ & -0.0561 & $-0.376 * * *$ \\
\hline & & $(0.0717)$ & & $(0.107)$ & $(0.138)$ & $(0.120)$ & $(0.112)$ & $(0.0542)$ & $(0.0997)$ \\
\hline \multirow{6}{*}{$\begin{array}{l}\text { 2SLS Estimation } \\
\text { with Education }\end{array}$} & Transport & -0.405 & $0.0266^{* *}$ & 0.152 & $0.245^{*}$ & -0.261 & $0.307 * *$ & 0.0106 & $-0.586^{* * *}$ \\
\hline & & $(0.251)$ & $(0.0128)$ & $(0.293)$ & $(0.131)$ & $(0.170)$ & $(0.132)$ & $(0.0672)$ & $(0.130)$ \\
\hline & Leisure & 0.501 & -0.0143 & -0.0697 & 0.362 & -0.00729 & 0.233 & -0.0160 & -0.0179 \\
\hline & & $(0.739)$ & (0.0279) & $(0.691)$ & $(0.468)$ & $(0.149)$ & $(0.348)$ & $(0.120)$ & $(0.178)$ \\
\hline & Total & -0.153 & 0.0135 & 0.323 & $0.228^{*}$ & -0.151 & $0.266^{* *}$ & -0.00350 & $-0.381 * * *$ \\
\hline & & $(0.249)$ & $(0.0123)$ & $(0.243)$ & $(0.119)$ & $(0.140)$ & $(0.114)$ & $(0.0640)$ & $(0.112)$ \\
\hline
\end{tabular}

\section{Appendix A Parallel Trend Graphs - Covariates}

Figure 7 Parallel Trends: Wealth Score

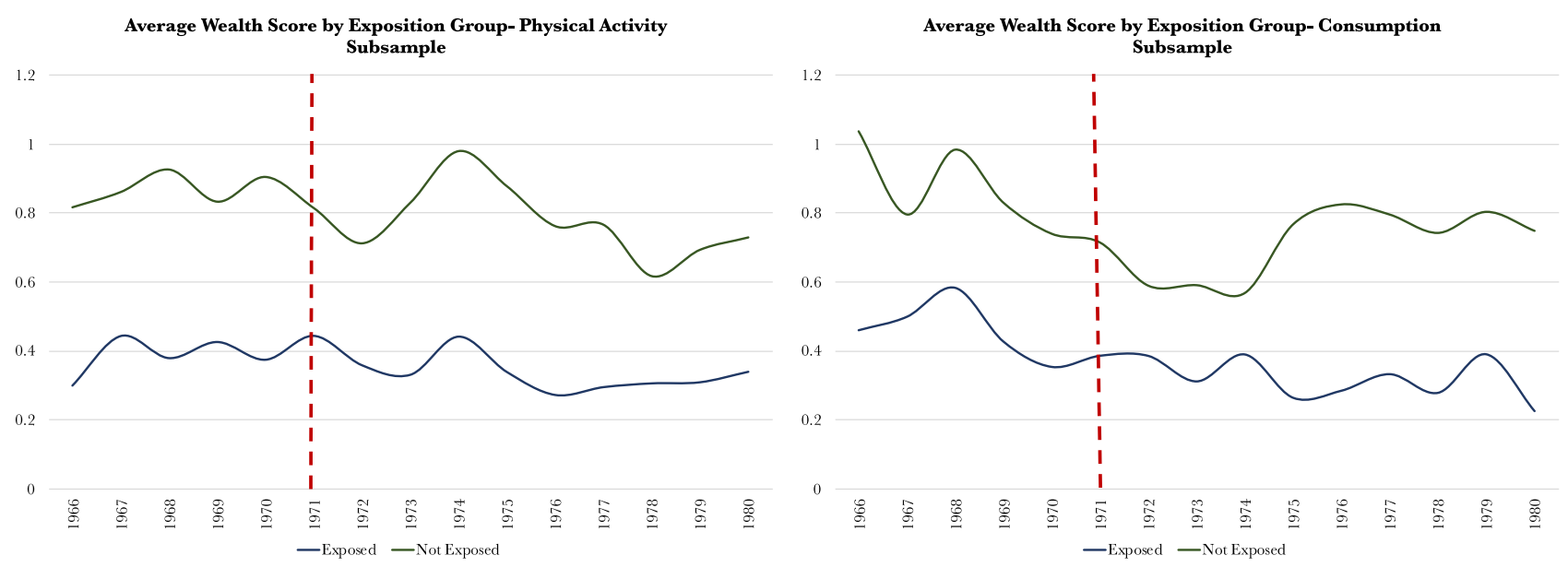


Figure 8 Parallel Trends: Sex (Male=1)
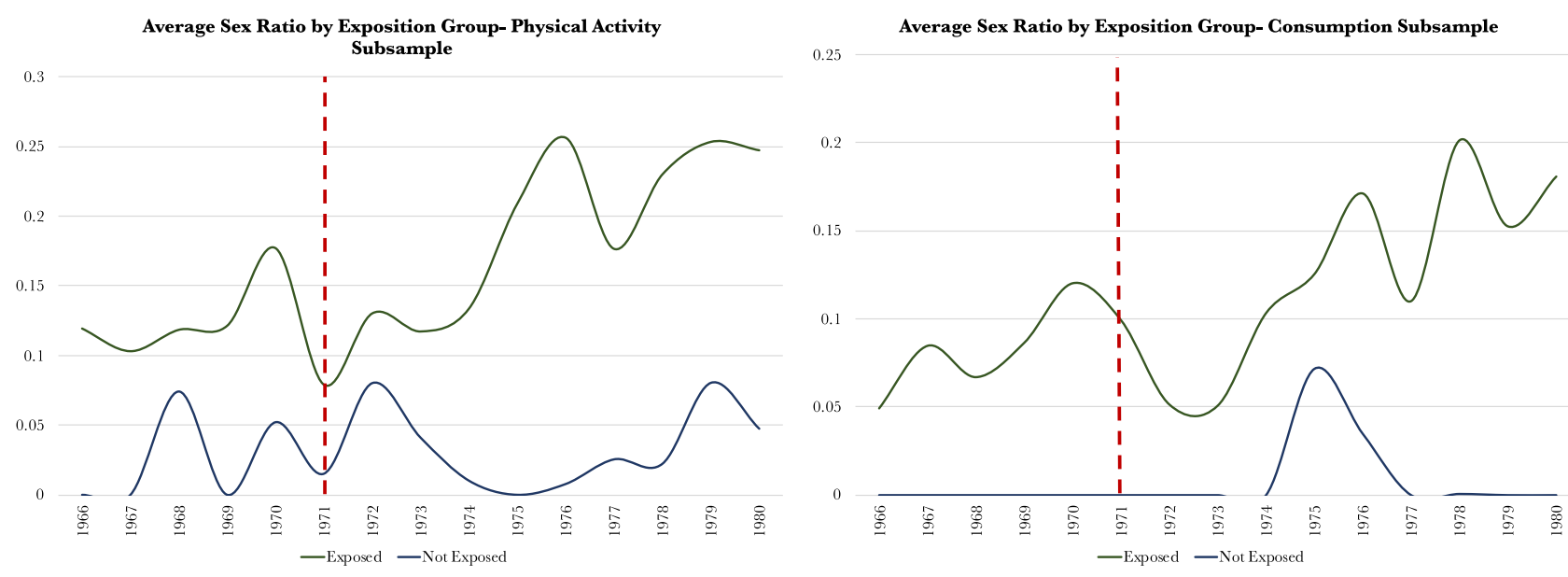

Figure 9 Parallel Trends: Contributive Regime
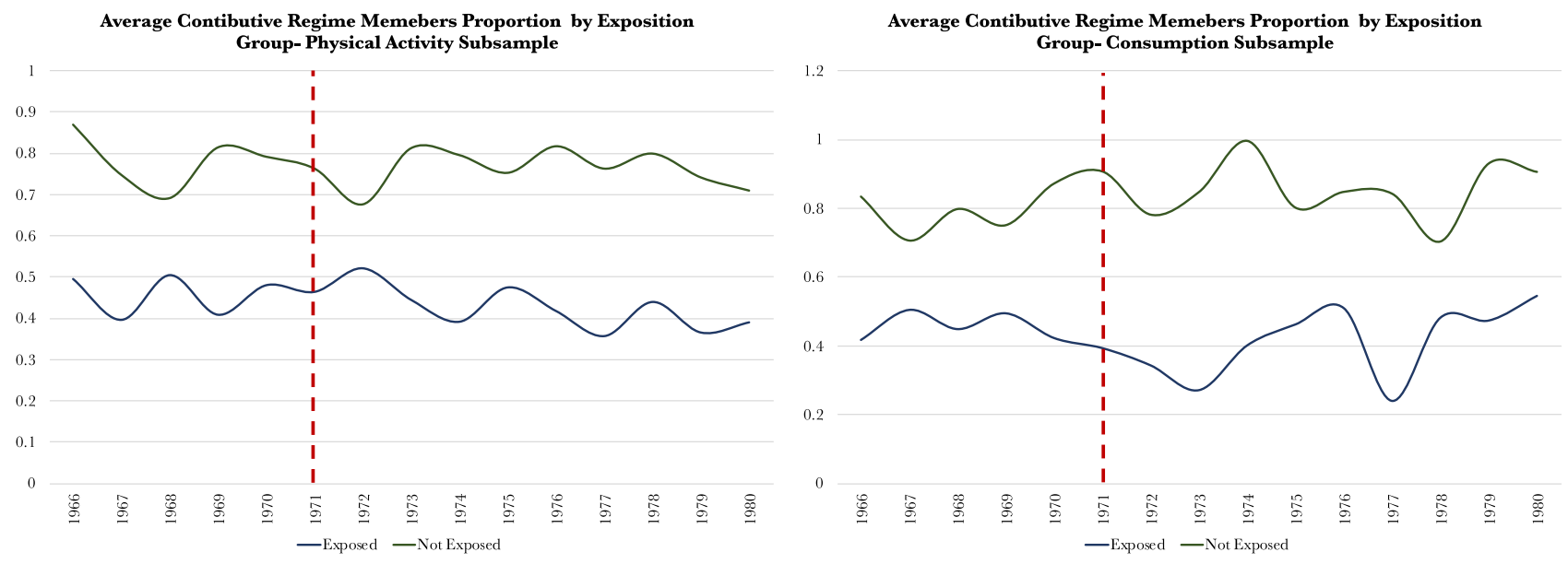

Figure 10 Parallel Trends: Subsidized Regime
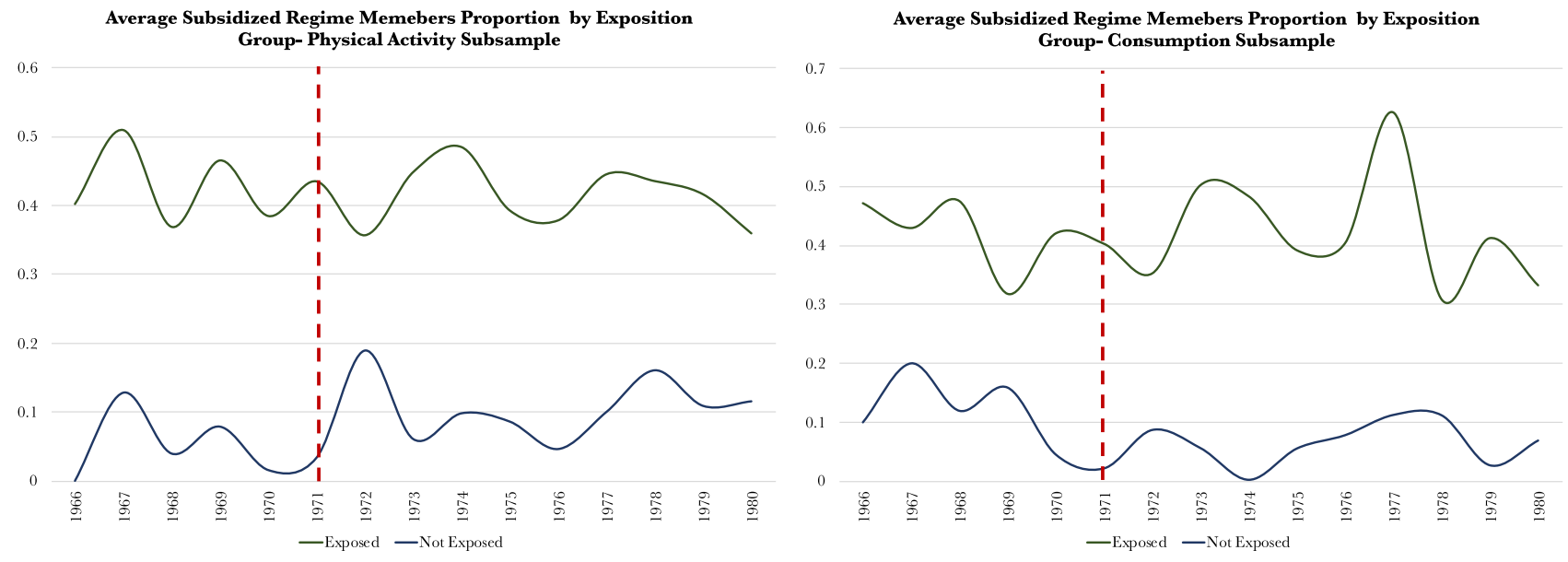
Figure 11 Parallel Trends: Ownership Variables
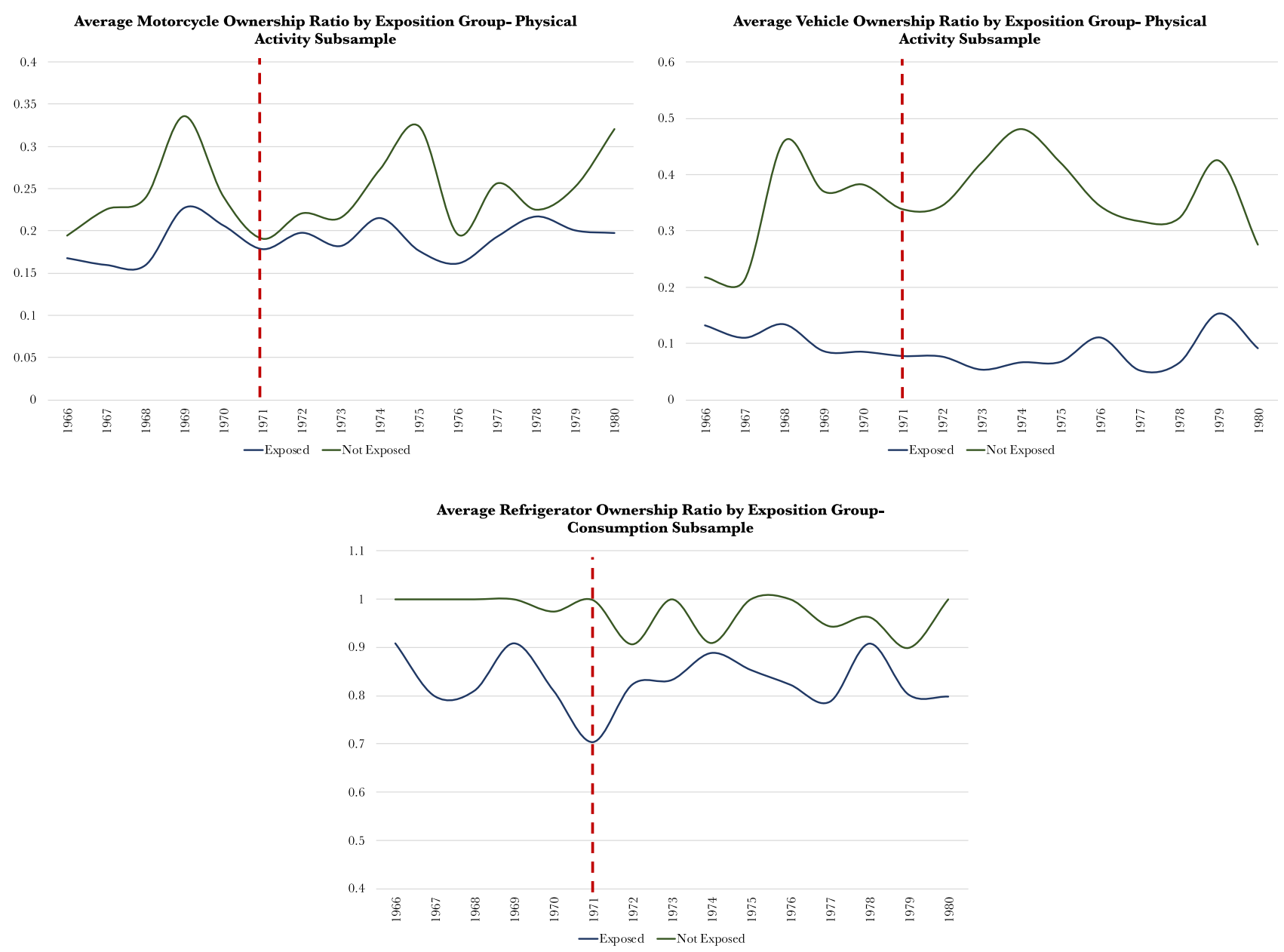

Table 19 Difference of means and proportions as a function of the exposition group

\begin{tabular}{|c|c|c|c|c|c|c|c|c|c|}
\hline \multicolumn{5}{|c|}{ Physical Activity Subsample } & \multicolumn{5}{|c|}{ Consumption Habits Subsample } \\
\hline Sex & & 0.18 & 0.05 & $0.12 * * *$ & Sex & & 0.13 & 0.03 & $0.09 * * *$ \\
\hline Education (years) & 9.48 & 8.1 & 14.51 & $-6.41 * * *$ & Education (years) & 9.86 & 8.21 & 14.41 & $-9.86 * * *$ \\
\hline Wealth Score & 0.20 & 0.11 & 0.57 & $-0.45 * * *$ & Wealth Score & 0.16 & 0.04 & 0.51 & $-0.47 * * *$ \\
\hline Subsidized & & 0.50 & 0.12 & $0.38 * * *$ & Subsidized & & 0.50 & 0.12 & $0.38^{* * *}$ \\
\hline Special & & 0.02 & 0.07 & $-0.05 * * *$ & Special & & 0.02 & 0.06 & $-0.04 * * *$ \\
\hline Not Affiliated & & 0.12 & 0.09 & $0.02 * * *$ & Not Affiliated & & 0.11 & 0.04 & 0.07 \\
\hline Occupation & & & & & Occupation & & & & \\
\hline Employed & & 0.55 & 0.72 & $-0.18 * * *$ & Employed & & 0.50 & 0.69 & $-0.19 * * *$ \\
\hline
\end{tabular}

Table 20 Correlation Coefficients Between Education Series (Exposed vs Not Exposed)

\begin{tabular}{c|ccccc} 
& Total & Before 1971 & $1966-1971$ & $1971-1977$ & After 1977 \\
\hline Corr( Exposed, Not Exposed) & 0.433 & 0.603 & 0.831 & 0.797 & 0.710
\end{tabular}




\section{Appendix B: Complete Regression Outputs- Physical Activity}

Output 1 OLS Results on Physical Activity Variables

\begin{tabular}{|c|c|c|c|c|c|c|}
\hline \multirow[b]{2}{*}{ VARIABLES } & \multicolumn{6}{|c|}{ Physical Activity (min/week) } \\
\hline & Transport & Leisure & Total & Transport & Leisure & Total \\
\hline Education (years) & -1.945 & $4.776 * * *$ & $2.831 * *$ & $12.40^{* * * *}$ & 3.427 & $15.82^{* * *}$ \\
\hline Education ${ }^{2}$ & $(1.238)$ & $(0.657)$ & (1.438) & $\begin{array}{c}(4.334) \\
-0.773 * * * \\
(0.217)\end{array}$ & $\begin{array}{l}(2.359) \\
0.0727 \\
(0.135)\end{array}$ & $\begin{array}{c}(4.987) \\
-0.700^{* * * *} \\
(0.258)\end{array}$ \\
\hline Sex $($ Male $=1)$ & $\begin{array}{c}109.7 * * * \\
(10.65)\end{array}$ & $\begin{array}{c}64.76 * * * \\
(5.959)\end{array}$ & $\begin{array}{c}174.4^{* * * *} \\
(12.62)\end{array}$ & $\begin{array}{c}108.9 * * * \\
(10.65)\end{array}$ & $\begin{array}{c}64.83 * * * \\
(5.969)\end{array}$ & $\begin{array}{c}173.7 * * * \\
(12.63)\end{array}$ \\
\hline Age & $\begin{array}{c}63.35 \\
(69.41)\end{array}$ & $\begin{array}{c}30.03 \\
(64.05)\end{array}$ & $\begin{array}{c}93.38 \\
(99.60)\end{array}$ & $\begin{array}{c}64.22 \\
(69.30)\end{array}$ & $\begin{array}{c}29.95 \\
(63.99)\end{array}$ & $\begin{array}{c}94.17 \\
(99.69)\end{array}$ \\
\hline $\mathrm{Age}^{2}$ & $\begin{array}{l}-0.719 \\
(0.777)\end{array}$ & $\begin{array}{l}-0.350 \\
(0.717)\end{array}$ & $\begin{array}{l}-1.069 \\
(1.115)\end{array}$ & $\begin{array}{l}-0.727 \\
(0.776)\end{array}$ & $\begin{array}{l}-0.349 \\
(0.717)\end{array}$ & $\begin{array}{l}-1.076 \\
(1.116)\end{array}$ \\
\hline $\begin{array}{l}\text { Occupation } \\
\text { Base = Employed }\end{array}$ & & & & & & \\
\hline Unemployed & $\begin{array}{l}-7.930 \\
(26.98)\end{array}$ & $\begin{array}{l}43.88^{* * *} \\
(18.02)\end{array}$ & $\begin{array}{c}35.95 \\
(35.67)\end{array}$ & $\begin{array}{l}-6.937 \\
(26.97)\end{array}$ & $\begin{array}{c}43.78 * * \\
(18.00)\end{array}$ & $\begin{array}{c}36.85 \\
(35.73)\end{array}$ \\
\hline Inactive & $\begin{array}{c}-51.88 * * * * \\
(9.478)\end{array}$ & $\begin{array}{c}25.13 * * * \\
(5.872)\end{array}$ & $\begin{array}{c}-26.75 * * \\
(11.59)\end{array}$ & $\begin{array}{c}-54.28 * * * * \\
(9.530)\end{array}$ & $\begin{array}{c}25.35 * * * \\
(5.877)\end{array}$ & $\begin{array}{c}-28.92 * * \\
(11.63)\end{array}$ \\
\hline $\begin{array}{l}\text { Social Security Reg } \\
\text { Base }=\text { Contributive }\end{array}$ & & & & & & \\
\hline Subsidized Regime & $\begin{array}{l}29.19 * * \\
(12.30)\end{array}$ & $\begin{array}{l}-1.677 \\
(5.188)\end{array}$ & $\begin{array}{l}27.52^{* *} \\
(13.74)\end{array}$ & $\begin{array}{l}29.50^{* * *} \\
(12.31)\end{array}$ & $\begin{array}{l}-1.706 \\
(5.184)\end{array}$ & $\begin{array}{l}27.79 * * \\
(13.75)\end{array}$ \\
\hline Special Regime & $\begin{array}{l}-1.249 \\
(18.47)\end{array}$ & $\begin{array}{c}24.96 \\
(15.26)\end{array}$ & $\begin{array}{l}23.71 \\
(25.44)\end{array}$ & $\begin{array}{l}3.575 \\
(18.59)\end{array}$ & $\begin{array}{l}24.50 \\
(15.26)\end{array}$ & $\begin{array}{l}28.08 \\
(25.62)\end{array}$ \\
\hline Not Affiliated & $\begin{array}{l}39.84 * * \\
(17.07)\end{array}$ & $\begin{array}{c}5.141 \\
(8.257)\end{array}$ & $\begin{array}{l}44.98^{* * *} \\
(19.78)\end{array}$ & $\begin{array}{l}39.45^{* * *} \\
(17.08)\end{array}$ & $\begin{array}{c}5.178 \\
(8.254)\end{array}$ & $\begin{array}{l}44.62^{* * *} \\
(19.78)\end{array}$ \\
\hline Owns Motorcycle & $\begin{array}{c}-44.90 * * * \\
(9.034)\end{array}$ & $\begin{array}{c}8.222 \\
(7.217)\end{array}$ & $\begin{array}{c}-36.67 * * * \\
(12.06)\end{array}$ & $\begin{array}{c}-46.94 * * * * \\
(9.039)\end{array}$ & $\begin{array}{c}8.414 \\
(7.295)\end{array}$ & $\begin{array}{c}-38.53 * * * \\
(12.12)\end{array}$ \\
\hline Owns Vehicle & $\begin{array}{c}-84.53 * * * \\
(12.42)\end{array}$ & $\begin{array}{l}20.88^{* * *} \\
(8.652)\end{array}$ & $\begin{array}{c}-63.65 * * * \\
(15.81)\end{array}$ & $\begin{array}{c}-77.88 * * * \\
(12.48)\end{array}$ & $\begin{array}{l}20.26^{* * *} \\
(8.681)\end{array}$ & $\begin{array}{c}-57.63 * * * \\
(15.83)\end{array}$ \\
\hline Constant & $\begin{array}{l}-945.7 \\
(1,262) \\
\end{array}$ & $\begin{array}{l}-498.9 \\
(1,163)\end{array}$ & $\begin{array}{l}-1,445 \\
(1,811)\end{array}$ & $\begin{array}{l}-1,018 \\
(1,260)\end{array}$ & $\begin{array}{l}-492.2 \\
(1,160)\end{array}$ & $\begin{array}{l}-1,510 \\
(1,812)\end{array}$ \\
\hline Observations & 10,993 & 10,993 & 10,993 & 10,993 & 10,993 & 10,993 \\
\hline $\mathrm{R}$-squared & 0.115 & 0.076 & 0.114 & 0.116 & 0.076 & 0.115 \\
\hline
\end{tabular}

Output 2 2SLS Results on Physical Activity Variables- One Instrument

\begin{tabular}{|c|c|c|c|}
\hline \multirow[b]{2}{*}{ VARIABLES } & \multicolumn{3}{|c|}{ Physical Activity (min/week) } \\
\hline & Transport & Leisure & Total \\
\hline Education (years) & $\begin{array}{c}24.24 \\
(19.17)\end{array}$ & $\begin{array}{c}11.01 \\
(13.26)\end{array}$ & $\begin{array}{l}35.25 \\
(24.21)\end{array}$ \\
\hline Exposition Dummy & $\begin{array}{l}121.9 \\
(95.42)\end{array}$ & $\begin{array}{l}35.65 \\
(66.41)\end{array}$ & $\begin{array}{l}157.6 \\
(121.1)\end{array}$ \\
\hline Sex $($ Male $=1)$ & $\begin{array}{l}69.63^{* * *} \\
(28.19)\end{array}$ & $\begin{array}{c}93.85^{*} \text { *k* } \\
(18.67)\end{array}$ & 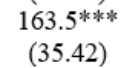 \\
\hline Age & $\begin{array}{l}195.4^{* *} \cdot \\
(76.48)\end{array}$ & $\begin{array}{c}10.55 \\
(52.32)\end{array}$ & $\begin{array}{l}205.9^{* * k} \\
(97.40)\end{array}$ \\
\hline Age $^{2}$ & $\begin{array}{l}-2.174^{*} \cdot k^{*} \\
(0.854)\end{array}$ & $\begin{array}{l}-0.123 \\
(0.583)\end{array}$ & $\begin{array}{c}-2.297^{*} * k^{*} \\
(1.087)\end{array}$ \\
\hline $\begin{array}{l}\text { Occupation } \\
\text { Base = Employed }\end{array}$ & & & \\
\hline Unemployed & $\begin{array}{l}-28.08 \\
(38.75)\end{array}$ & $\begin{array}{c}5.345 \\
(25.20)\end{array}$ & $\begin{array}{l}-22.73 \\
(46.17)\end{array}$ \\
\hline Inactive & $\begin{array}{l}-22.58 \\
(13.98)\end{array}$ & $\begin{array}{c}9.609 \\
(9.122)\end{array}$ & $\begin{array}{l}-12.97 \\
(17.38)\end{array}$ \\
\hline $\begin{array}{l}\text { Social Security Reg } \\
\text { Base }=\text { Contributive }\end{array}$ & & & \\
\hline Subsidized Regime & $\begin{array}{l}87.45^{* *} \cdot \\
(36.53)\end{array}$ & $\begin{array}{c}14.61 \\
(24.49)\end{array}$ & $\begin{array}{l}102.1^{* * *} \\
(45.48)\end{array}$ \\
\hline Special Regime & $\begin{array}{l}-18.58 \\
(24.08)\end{array}$ & $\begin{array}{l}34.53^{*} \\
(20.93)\end{array}$ & $\begin{array}{l}15.96 \\
(35.49)\end{array}$ \\
\hline Not Affiliated & $\begin{array}{l}91.03^{*} \cdot k_{k} \cdot k \\
(33.23)\end{array}$ & $\begin{array}{c}12.05 \\
(18.60)\end{array}$ & $\begin{array}{c}103.1^{\text {*k** }} \\
(39.14)\end{array}$ \\
\hline Owns Motorcycle & $\begin{array}{c}-24.56^{* * *} \\
(12.49)\end{array}$ & $\begin{array}{l}-0.377 \\
(8.435)\end{array}$ & $\begin{array}{l}-24.94 \\
(15.86)\end{array}$ \\
\hline Owns Vehicle & 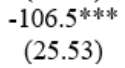 & $\begin{array}{c}11.03 \\
(13.69)\end{array}$ & $\begin{array}{c}-95.44^{* * * *} * \\
(30.49)\end{array}$ \\
\hline Constant & $\begin{array}{c}-3,862^{* * *} \\
(1,511)\end{array}$ & $\begin{array}{l}-287.4 \\
(1,027)\end{array}$ & $\begin{array}{c}-4,149 * * \\
(1,917)\end{array}$ \\
\hline Observations & 5,576 & 5,576 & 5,576 \\
\hline R-squared & 0.097 & 0.095 & 0.098 \\
\hline
\end{tabular}


Output 3 2SLS Results on Physical Activity Variables-Several Instruments

\begin{tabular}{|c|c|c|c|}
\hline \multirow[b]{2}{*}{ VARIABLES } & \multicolumn{3}{|c|}{ Physical Activity (min/week) } \\
\hline & Transport & Leisure & Total \\
\hline \multirow[t]{2}{*}{ Education (years) } & -75.55 & $89.73 * *$ & 14.18 \\
\hline & $(71.70)$ & $(42.69)$ & $(84.69)$ \\
\hline \multirow[t]{2}{*}{ Education $^{2}$} & 4.493 & -3.325 & 1.168 \\
\hline & $(3.474)$ & $(2.054)$ & $(4.106)$ \\
\hline \multicolumn{4}{|l|}{ Education of the mother } \\
\hline \multirow[t]{2}{*}{ None } & 36.97 & 206.3 & 243.3 \\
\hline & $(241.9)$ & $(165.2)$ & $(298.0)$ \\
\hline \multirow[t]{2}{*}{ Primary Schooling } & 75.33 & 178.4 & 253.7 \\
\hline & $(210.1)$ & $(141.5)$ & $(256.0)$ \\
\hline \multirow[t]{2}{*}{ Secondary Schooling } & 145.9 & 14.04 & 159.9 \\
\hline & $(124.3)$ & $(81.91)$ & $(151.4)$ \\
\hline Sex $($ Male $=1)$ & $\begin{array}{c}89.25 \\
(73.26)\end{array}$ & $\begin{array}{c}34.30 \\
(46.63)\end{array}$ & $\begin{array}{c}123.5 \\
(87.88)\end{array}$ \\
\hline \multirow[t]{2}{*}{ Age } & $180.2^{* *}$ & 17.43 & $197.6^{* *}$ \\
\hline & $(77.08)$ & $(53.49)$ & $(96.37)$ \\
\hline \multirow[t]{2}{*}{ Age $^{2}$} & $-2.000 * *$ & -0.220 & $-2.220^{* *}$ \\
\hline & $(0.864)$ & $(0.599)$ & $(1.081)$ \\
\hline \multicolumn{4}{|l|}{ Occupation } \\
\hline \multicolumn{4}{|l|}{ Base $=$ Employed } \\
\hline \multirow[t]{2}{*}{ Unemployed } & -12.76 & -3.112 & -15.88 \\
\hline & $(38.08)$ & $(26.43)$ & $(44.28)$ \\
\hline \multirow[t]{2}{*}{ Inactive } & -24.41 & 12.95 & -11.46 \\
\hline & $(16.33)$ & $(10.91)$ & (19.91) \\
\hline \multicolumn{4}{|l|}{ Social Security Regime } \\
\hline \multicolumn{4}{|l|}{ Base $=$ Contributive } \\
\hline \multirow[t]{2}{*}{ Subsidized Regime } & $58.20^{*}$ & 31.13 & $89.33^{* * *}$ \\
\hline & $(35.19)$ & $(23.18)$ & $(42.40)$ \\
\hline \multirow[t]{2}{*}{ Special Regime } & -33.13 & $42.33^{*}$ & 9.203 \\
\hline & $(30.85)$ & $(24.11)$ & $(42.65)$ \\
\hline \multirow[t]{2}{*}{ Not Affiliated } & $76.30 * *$ & 24.51 & $100.8^{* * *}$ \\
\hline & $(35.42)$ & $(21.38)$ & (41.81) \\
\hline \multirow[t]{2}{*}{ Owns Motorcycle } & -7.203 & -11.19 & -18.39 \\
\hline & (16.59) & $(11.47)$ & (20.81) \\
\hline \multirow[t]{2}{*}{ Owns Vehicle } & $-118.3 * * *$ & 22.49 & $-95.77 * *$ \\
\hline & $(32.53)$ & $(16.81)$ & (37.54) \\
\hline \multirow[t]{2}{*}{ Constant } & $-3,088^{* *}$ & -835.9 & $-3,924 * *$ \\
\hline & $(1,543)$ & $(1,082)$ & $(1,932)$ \\
\hline Observations & 5,576 & 5,576 & 5,576 \\
\hline R-squared & 0.086 & -0.016 & 0.104 \\
\hline
\end{tabular}

Output 4 2SLS Results on Physical Activity Variables Including Wealth Score-One Instrument

\begin{tabular}{|c|c|c|c|c|c|c|}
\hline \multirow[b]{2}{*}{ VARIABLES } & \multicolumn{6}{|c|}{ Physical Activity (min/week) } \\
\hline & Transport & Leisure & Total & Transport & Leisure & Total \\
\hline Education (years) & $\begin{array}{l}21.57 \\
(17.15)\end{array}$ & $\begin{array}{c}10.87 \\
(11.54)\end{array}$ & $\begin{array}{c}32.44 \\
(21.26)\end{array}$ & $\begin{array}{c}22.44 \\
(18.14)\end{array}$ & $\begin{array}{c}10.69 \\
(12.54)\end{array}$ & $\begin{array}{c}33.13 \\
(22.88)\end{array}$ \\
\hline Exposition Dummy & $\begin{array}{c}124.4 \\
(88.34)\end{array}$ & $\begin{array}{c}34.90 \\
(59.05)\end{array}$ & $\begin{array}{c}159.3 \\
(109.8)\end{array}$ & $\begin{array}{c}102.5 \\
(84.65)\end{array}$ & $\begin{array}{c}32.21 \\
(58.81)\end{array}$ & $\begin{array}{c}134.7 \\
(107.3)\end{array}$ \\
\hline Wealth Score & $\begin{array}{c}-75.92 * * \\
(33.08)\end{array}$ & $\begin{array}{l}-9.163 \\
(21.50)\end{array}$ & $\begin{array}{l}-85.08 * * \\
(40.35)\end{array}$ & $\begin{array}{l}-46.69 * \\
(27.62)\end{array}$ & $\begin{array}{l}-8.251 \\
(19.27)\end{array}$ & $\begin{array}{l}-54.94 \\
(34.65)\end{array}$ \\
\hline Sex $($ Male $=1)$ & $\begin{array}{l}85.49 * * * \\
(27.19)\end{array}$ & $\begin{array}{c}96.09 * * * \\
(17.35)\end{array}$ & $\begin{array}{c}181.6 * * * \\
(33.63)\end{array}$ & $\begin{array}{c}76.51 * * * \\
(25.46)\end{array}$ & $\begin{array}{l}95.07 * * * \\
(16.90)\end{array}$ & $\begin{array}{c}171.6 * * * \\
(31.96)\end{array}$ \\
\hline Age & $\begin{array}{l}185.5^{* * *} \\
(76.55)\end{array}$ & $\begin{array}{c}12.09 \\
(51.00)\end{array}$ & $\begin{array}{l}197.6 * * \\
(96.15)\end{array}$ & $\begin{array}{l}194.5^{* * *} \\
(76.38)\end{array}$ & $\begin{array}{c}10.39 \\
(52.15)\end{array}$ & $\begin{array}{l}204.9 * * \\
(97.02)\end{array}$ \\
\hline $\mathrm{Age}^{2}$ & $\begin{array}{c}-2.064 * * \\
(0.855)\end{array}$ & $\begin{array}{l}-0.139 \\
(0.569)\end{array}$ & $\begin{array}{c}-2.203 * * \\
(1.073)\end{array}$ & $\begin{array}{c}-2.160^{* *} \\
(0.852)\end{array}$ & $\begin{array}{l}-0.121 \\
(0.581)\end{array}$ & $\begin{array}{c}-2.280 * * \\
(1.082)\end{array}$ \\
\hline $\begin{array}{l}\text { Occupation } \\
\text { Base }=\text { Employed }\end{array}$ & & & & & & \\
\hline Unemployed & & & & $\begin{array}{l}-22.20 \\
(36.99)\end{array}$ & $\begin{array}{c}6.385 \\
(23.98)\end{array}$ & $\begin{array}{l}-15.81 \\
(43.93)\end{array}$ \\
\hline Inactive & & & & $\begin{array}{l}-24.80^{*} \\
(13.27)\end{array}$ & $\begin{array}{l}9.216 \\
(8.557)\end{array}$ & $\begin{array}{l}-15.59 \\
(16.44)\end{array}$ \\
\hline $\begin{array}{l}\text { Social Security Regi } \\
\text { Base }=\text { Contributive }\end{array}$ & & & & & & \\
\hline Subsidized Regime & & & & $\begin{array}{l}71.98^{* * *} \\
(29.23)\end{array}$ & $\begin{array}{c}11.88 \\
(18.74)\end{array}$ & $\begin{array}{l}83.85 * * \\
(35.78)\end{array}$ \\
\hline Special Regime & & & & $\begin{array}{l}-15.61 \\
(23.14)\end{array}$ & $\begin{array}{l}35.06^{*} \\
(20.44)\end{array}$ & $\begin{array}{c}19.44 \\
(34.43)\end{array}$ \\
\hline Not Affiliated & & & & $\begin{array}{l}81.95 * * * \\
(29.69)\end{array}$ & $\begin{array}{c}10.45 \\
(15.86)\end{array}$ & $\begin{array}{c}92.40 * * * \\
(34.54)\end{array}$ \\
\hline Owns Motorcycle & & & & $\begin{array}{l}-16.88 \\
(11.35)\end{array}$ & $\begin{array}{c}0.981 \\
(8.978)\end{array}$ & $\begin{array}{l}-15.90 \\
(15.48)\end{array}$ \\
\hline Owns Vehicle & & & & $\begin{array}{l}-89.83 * * * \\
(19.25)\end{array}$ & $\begin{array}{c}13.97 \\
(10.80)\end{array}$ & $\begin{array}{c}-75.86 * * * \\
(23.28)\end{array}$ \\
\hline Constant & $\begin{array}{c}-3,606 * * \\
(1,471)\end{array}$ & $\begin{array}{l}-298.2 \\
(972.7) \\
\end{array}$ & $\begin{array}{c}-3,904 * * \\
(1,840)\end{array}$ & $\begin{array}{c}-3,787 * * \\
(1,493)\end{array}$ & $\begin{array}{l}-274.1 \\
(1,012)\end{array}$ & $\begin{array}{c}-4,061^{* *} \\
(1,889) \\
\end{array}$ \\
\hline Observations & 5,592 & 5,592 & 5,592 & 5,576 & 5,576 & 5,576 \\
\hline R-squared & 0.091 & 0.095 & 0.099 & 0.108 & 0.097 & 0.109 \\
\hline
\end{tabular}


Output 5 2SLS Results on Physical Activity Including Wealth Score- Several Instruments

\begin{tabular}{|c|c|c|c|c|c|c|}
\hline \multirow[b]{2}{*}{ VARIABLES } & \multicolumn{6}{|c|}{ Physical Activity (min/week) } \\
\hline & Transport & Leisure & Total & Transport & Leisure & Total \\
\hline \multirow[t]{2}{*}{ Education (years) } & -62.24 & $88.04^{\text {wk }}$ & 25.80 & -77.76 & $90.84^{k * * *}$ & 13.08 \\
\hline & $(70.88)$ & $(41.95)$ & $(83.94)$ & $(71.99)$ & $(42.62)$ & (84.63) \\
\hline \multirow[t]{2}{*}{ Education $^{2}$} & 3.594 & -3.235 & 0.359 & 4.472 & $-3.466^{*}$ & 1.006 \\
\hline & Education of the mother & $(2.012)$ & $(4.029)$ & $(3.513)$ & $(2.071)$ & $(4.135)$ \\
\hline \multirow{2}{*}{ None } & 21.54 & 195.8 & 217.3 & 3.452 & 179.4 & 182.8 \\
\hline & (207.4) & $(137.9)$ & $(251.4)$ & (215.1) & $(144.8)$ & $(262.7)$ \\
\hline \multirow[t]{2}{*}{ Primary Schooling } & 63.86 & 175.5 & 239.3 & 47.54 & 156.6 & 204.1 \\
\hline & $(185.0)$ & $(121.2)$ & $(221.9)$ & (188.7) & (125.3) & (228.1) \\
\hline \multirow[t]{2}{*}{ Secondary Schooling } & 128.4 & 15.06 & 143.5 & 132.2 & 0.835 & 133.1 \\
\hline & $(114.8)$ & (73.84) & $(137.9)$ & (117.3) & (76.16) & $(141.8)$ \\
\hline \multirow[t]{2}{*}{ Wealth Score } & -43.34 & -25.46 & -68.80 ** & -16.65 & -22.70 & -39.35 \\
\hline & $(28.19)$ & $(18.38)$ & $(33.75)$ & $(23.98)$ & (16.08) & (29.00) \\
\hline \multirow[t]{2}{*}{$\operatorname{Sex}($ Male $=1)$} & 106.3 & 38.88 & $145.2^{*}$ & 99.19 & 42.43 & $141.6^{*}$ \\
\hline & $(65.52)$ & $(40.71)$ & $(77.34)$ & $(65.15)$ & (40.84) & $(77.46)$ \\
\hline \multirow[t]{2}{*}{ Age } & $168.6^{* *}$ & 20.24 & $188.8^{* * *}$ & $179.0^{\text {*** }}$ & 17.11 & $196.1^{* * *}$ \\
\hline & $(76.09)$ & $(52.32)$ & (94.66) & $(76.98)$ & $(53.06)$ & $(95.79)$ \\
\hline \multirow[t]{2}{*}{$\mathrm{Age}^{2}$} & $-1.874^{* * *}$ & -0.248 & $-2.122^{* *}$ & $-1.984^{* *}$ & -0.213 & $-2.197^{* * *}$ \\
\hline \multirow{2}{*}{\multicolumn{7}{|c|}{$\begin{array}{l}\text { Occupation } \\
\text { Base=Emploved }\end{array}$}} \\
\hline & & & & & & \\
\hline Unemployed & & & & $\begin{array}{l}-9.893 \\
(36.80)\end{array}$ & $\begin{array}{l}-0.435 \\
(25.47)\end{array}$ & $\begin{array}{l}-10.33 \\
(42.58)\end{array}$ \\
\hline \multirow[t]{2}{*}{ Inactive } & & & & $-26.15^{*}$ & 11.39 & -14.76 \\
\hline & & & & $(15.55)$ & $(10.15)$ & (18.76) \\
\hline \multicolumn{7}{|l|}{$\begin{array}{l}\text { Social Security Regime } \\
\text { Base=Contributive }\end{array}$} \\
\hline \multirow{2}{*}{ Subsidized Regime } & & & & & & $74.78^{* *}$ \\
\hline & & & & (29.40) & $(18.36)$ & $(34.68)$ \\
\hline \multirow[t]{2}{*}{ Special Regime } & & & & -31.00 & $44.75^{*}$ & 13.75 \\
\hline & & & & $(30.10)$ & $(23.60)$ & (41.57) \\
\hline \multirow[t]{2}{*}{ Not Affiliated } & & & & $71.30^{* * *}$ & 19.60 & $90.90^{* * *}$ \\
\hline & & & & $(32.35)$ & (18.68) & (37.58) \\
\hline \multirow[t]{2}{*}{ Owns Motorcycle } & & & & & & \\
\hline & & & & (15.37) & (11.42) & (19.89) \\
\hline \multirow{2}{*}{ Owns Vehicle } & & & & $-111.3^{* * * * *}$ & $31.24^{*}$ & -80.06 ** \\
\hline & & & & $(31.28)$ & (16.18) & $(36.01)$ \\
\hline \multirow[t]{2}{*}{ Constant } & $-2,867^{*}$ & -851.4 & $-3,719^{* *}$ & $-3,018^{* * *}$ & -801.6 & $-3,820^{* * *}$ \\
\hline & $(1,485)$ & $(1,030)$ & $(1,850)$ & $(1,523)$ & $(1,061)$ & $(1,900)$ \\
\hline Observations & 5,592 & 5,592 & 5,592 & 5,576 & 5,576 & 5,576 \\
\hline R-squared & 0.086 & -0.014 & 0.107 & 0.089 & -0.010 & 0.116 \\
\hline
\end{tabular}

Output 6 2SLS Results on Physical Activity Variables- Ologit First Stage

\begin{tabular}{|c|c|c|c|c|c|c|}
\hline \multirow[b]{2}{*}{ VARIABLES } & \multicolumn{6}{|c|}{ Physical Activity (min/week) } \\
\hline & Transport & Leisure & Total & Transport & Leisure & Total \\
\hline Education (years) & $\begin{array}{c}0.668 \\
(2.713)\end{array}$ & $\begin{array}{l}4.117 * * \\
(1.635)\end{array}$ & $\begin{array}{c}4.784 \\
(3.259)\end{array}$ & $\begin{array}{c}1.401 \\
(2.925)\end{array}$ & $\begin{array}{l}4.076 * * \\
(1.781)\end{array}$ & $\begin{array}{l}5.478 \\
(3.522)\end{array}$ \\
\hline Wealth Score & & & & $\begin{array}{l}-17.41 \\
(12.37)\end{array}$ & $\begin{array}{c}0.953 \\
(7.007)\end{array}$ & $\begin{array}{l}-16.46 \\
(14.13)\end{array}$ \\
\hline Sex $($ Male $=1)$ & $\begin{array}{l}92.80 * * * \\
(18.33)\end{array}$ & $\begin{array}{c}100.6 * * * \\
(13.18)\end{array}$ & $\begin{array}{c}193.4 * * * \\
(23.43)\end{array}$ & $\begin{array}{c}93.99 * * * \\
(18.37)\end{array}$ & $\begin{array}{c}100.6 * * * \\
(13.20)\end{array}$ & $\begin{array}{c}194.6 * * * \\
(23.46)\end{array}$ \\
\hline Age & $\begin{array}{l}170.3 * * \\
(70.85)\end{array}$ & $\begin{array}{c}3.207 \\
(50.12)\end{array}$ & $\begin{array}{l}173.5^{*} \\
(90.81)\end{array}$ & $\begin{array}{l}171.4 * * \\
(70.83)\end{array}$ & $\begin{array}{c}3.143 \\
(50.18)\end{array}$ & $\begin{array}{l}174.6^{*} \\
(90.77)\end{array}$ \\
\hline $\mathrm{Age}^{2}$ & $\begin{array}{c}-1.907 * * \\
(0.795)\end{array}$ & $\begin{array}{l}-0.0450 \\
(0.561)\end{array}$ & $\begin{array}{l}-1.952^{*} \\
(1.018)\end{array}$ & $\begin{array}{c}-1.917 * * \\
(0.795)\end{array}$ & $\begin{array}{l}-0.0444 \\
(0.561)\end{array}$ & $\begin{array}{l}-1.962^{*} \\
(1.017)\end{array}$ \\
\hline $\begin{array}{l}\text { Occupation } \\
\text { Base }=\text { Employed }\end{array}$ & & & & & & \\
\hline Unemployed & $\begin{array}{l}-7.530 \\
(31.91)\end{array}$ & $\begin{array}{c}11.35 \\
(20.68)\end{array}$ & $\begin{array}{c}3.824 \\
(37.50)\end{array}$ & $\begin{array}{l}-6.559 \\
(31.93)\end{array}$ & $\begin{array}{c}11.30 \\
(20.70)\end{array}$ & $\begin{array}{c}4.741 \\
(37.53)\end{array}$ \\
\hline Inactive & $\begin{array}{c}-33.84 * * * \\
(11.20)\end{array}$ & $\begin{array}{l}6.317 \\
(6.715)\end{array}$ & $\begin{array}{c}-27.52^{* *} \\
(13.51)\end{array}$ & $\begin{array}{c}-34.00 * * * * \\
(11.20)\end{array}$ & $\begin{array}{c}6.326 \\
(6.714)\end{array}$ & $\begin{array}{c}-27.67 * * \\
(13.51)\end{array}$ \\
\hline $\begin{array}{l}\text { Social Security Reg } \\
\text { Base }=\text { Contributive }\end{array}$ & & & & & & \\
\hline Subsidized Regime & $\begin{array}{l}47.32 * * * \\
(15.83)\end{array}$ & $\begin{array}{l}2.876 \\
(8.477)\end{array}$ & $\begin{array}{l}50.19 * * * \\
(18.24)\end{array}$ & $\begin{array}{l}43.93 * * * \\
(15.83)\end{array}$ & $\begin{array}{c}3.061 \\
(8.146)\end{array}$ & $\begin{array}{c}47.00 * * * \\
(18.04)\end{array}$ \\
\hline Special Regime & $\begin{array}{l}-6.609 \\
(20.13)\end{array}$ & $\begin{array}{l}38.03 * * \\
(19.14)\end{array}$ & $\begin{array}{c}31.42 \\
(31.40)\end{array}$ & $\begin{array}{l}-6.217 \\
(20.12)\end{array}$ & $\begin{array}{l}38.01 * * \\
(19.14)\end{array}$ & $\begin{array}{l}31.79 \\
(31.38)\end{array}$ \\
\hline Not Affiliated & $\begin{array}{c}64.53 * * * \\
(21.99)\end{array}$ & $\begin{array}{c}4.306 \\
(10.75)\end{array}$ & $\begin{array}{c}68.83 * * * \\
(24.89)\end{array}$ & $\begin{array}{c}62.72 * * * \\
(21.95)\end{array}$ & $\begin{array}{c}4.405 \\
(10.76)\end{array}$ & $\begin{array}{c}67.13 * * * \\
(24.88)\end{array}$ \\
\hline Owns Motorcycle & $\begin{array}{l}-17.92 \\
(10.95)\end{array}$ & $\begin{array}{l}1.567 \\
(8.978)\end{array}$ & $\begin{array}{l}-16.35 \\
(15.10)\end{array}$ & $\begin{array}{l}-15.45 \\
(10.98)\end{array}$ & $\begin{array}{c}1.432 \\
(9.202)\end{array}$ & $\begin{array}{l}-14.02 \\
(15.28)\end{array}$ \\
\hline Owns Vehicle & $\begin{array}{c}-82.45 * * * \\
(15.45)\end{array}$ & $\begin{array}{c}18.05 \\
(11.03)\end{array}$ & $\begin{array}{c}-64.40 * * * * \\
(19.71)\end{array}$ & $\begin{array}{c}-77.68 * * * \\
(15.42)\end{array}$ & $\begin{array}{c}17.79 \\
(11.33)\end{array}$ & $\begin{array}{c}-59.89 * * * \\
(19.89)\end{array}$ \\
\hline Constant & $\begin{array}{c}-3,047 * * \\
(1,279)\end{array}$ & $\begin{array}{r}-49.16 \\
(915.6) \\
\end{array}$ & $\begin{array}{l}-3,096^{*} \\
(1,646) \\
\end{array}$ & $\begin{array}{c}-3,068 * * \\
(1,279) \\
\end{array}$ & $\begin{array}{c}-48.04 \\
(916.8) \\
\end{array}$ & $\begin{array}{l}-3,116^{*} \\
(1,645) \\
\end{array}$ \\
\hline Observations & 5,576 & 5,576 & 5,576 & 5,576 & 5,576 & 5,576 \\
\hline R-squared & 0.137 & 0.106 & 0.144 & 0.138 & 0.106 & 0.144 \\
\hline
\end{tabular}


Output 7 First Stages on Education- One and Several Variables

\begin{tabular}{lc}
\hline VARIABLES & $\begin{array}{c}\text { Education } \\
\text { (Years) }\end{array}$ \\
\hline Interacted Dummy & $1.545^{* * *}$ \\
& $(0.212)$ \\
Exposition Dummy & $-6.097 * * *$ \\
& $(0.191)$ \\
Sex (Male=1) & $0.913 * * *$ \\
& $(0.184)$ \\
Age & $-1.126 *$ \\
& $(0.632)$ \\
Age ${ }^{2}$ & $0.0124 *$ \\
& $(0.00707)$ \\
Occupation & \\
Base $=$ Employed & \\
Unemployed & $0.860 * * *$ \\
& $(0.304)$ \\
Inactive & $-0.474 * * *$ \\
& $(0.111)$ \\
Social Security Regime & \\
Base $=$ Contributive & \\
Subsidized Regime & $-1.723 * * *$ \\
& $(0.126)$ \\
Special Regime & 0.415 \\
& $(0.296)$ \\
Not Affiliated & $-1.148 * * *$ \\
& $(0.174)$ \\
Owns Motorcycle & $0.321 * * *$ \\
& $(0.109)$ \\
Owns Vehicle & $1.028 * * *$ \\
& $(0.148)$ \\
Constant & $35.26 * * *$ \\
& $(11.51)$ \\
\hline Observations & 5,576 \\
R-squared & 0.536 \\
\hline Robust standard errors in parentheses \\
$* * *$ p $<0.01, * * \mathrm{p}<0.05, * \mathrm{p}<0.1$ \\
\end{tabular}

\begin{tabular}{|c|c|c|}
\hline VARIABLES & $\begin{array}{l}\text { Education } \\
\text { (Years) }\end{array}$ & Education $^{2}$ \\
\hline Interacted Dummy 1 & $\begin{array}{l}2.328^{* *} \\
(1.018)\end{array}$ & $\begin{array}{l}42.79 * * \\
(18.94)\end{array}$ \\
\hline Interacted Dummy 2 & $\begin{array}{c}1.209 * * * \\
(0.250)\end{array}$ & $\begin{array}{c}21.73^{* * *} \\
(5.492)\end{array}$ \\
\hline Interacted Dummy 3 & $\begin{array}{c}0.945^{* * *} \\
(0.205)\end{array}$ & $\begin{array}{c}23.98^{* * *} \\
(4.999)\end{array}$ \\
\hline \multicolumn{3}{|l|}{ Education of the mother } \\
\hline None & $\begin{array}{c}-10.77^{* * *} \\
(0.676)\end{array}$ & $\begin{array}{c}-203.6^{* * * *} \\
(12.54)\end{array}$ \\
\hline Primary Schooling & $\begin{array}{c}-9.017^{* * *} \\
(0.217)\end{array}$ & $\begin{array}{c}-174.0^{* * *} \\
(4.812)\end{array}$ \\
\hline Secondary Schooling & $\begin{array}{c}-4.614^{* * *} \\
(0.181)\end{array}$ & $\begin{array}{l}-114.1^{* * * *} \\
(4.365)\end{array}$ \\
\hline Sex (Male $=1)$ & $\begin{array}{c}2.515^{* * * *} \\
(0.201)\end{array}$ & $\begin{array}{c}45.63^{* * *} \\
(4.003)\end{array}$ \\
\hline Age & $\begin{array}{l}-0.750 \\
(0.555)\end{array}$ & $\begin{array}{l}-14.63 \\
(11.34)\end{array}$ \\
\hline Age $^{2}$ & $\begin{array}{c}0.00883 \\
(0.00621)\end{array}$ & $\begin{array}{c}0.169 \\
(0.127)\end{array}$ \\
\hline \multicolumn{3}{|l|}{ Occupation } \\
\hline Unemployed & $\begin{array}{c}0.618^{* *} \\
(0.247)\end{array}$ & $\begin{array}{l}11.16^{* * *} \\
(4.664)\end{array}$ \\
\hline Inactive & $\begin{array}{c}-0.463^{* * *} \\
(0.0877)\end{array}$ & $\begin{array}{c}-9.965^{* * *} \\
(1.720)\end{array}$ \\
\hline \multicolumn{3}{|l|}{$\begin{array}{l}\text { Social Security Regime } \\
\text { Base }=\text { Contributive }\end{array}$} \\
\hline Subsidized Regime & $\begin{array}{c}-1.221^{* * *} \\
(0.101)\end{array}$ & $\begin{array}{c}-22.86^{* * * *} \\
(1.896)\end{array}$ \\
\hline Special Regime & $\begin{array}{l}0.434^{*} \\
(0.257)\end{array}$ & $\begin{array}{l}12.93 * * \\
(5.912)\end{array}$ \\
\hline Not Affiliated & $\begin{array}{c}-1.003^{* * *} \\
(0.152)\end{array}$ & $\begin{array}{c}-19.56^{* * * *} \\
(2.965)\end{array}$ \\
\hline Owns Motorcycle & $\begin{array}{c}0.179^{*} \\
(0.0916)\end{array}$ & $\begin{array}{c}0.537 \\
(1.882)\end{array}$ \\
\hline Owns Vehicle & $\begin{array}{c}0.707^{* * *} \\
(0.130)\end{array}$ & $\begin{array}{c}19.48^{* * *} \\
(2.962)\end{array}$ \\
\hline Constant & $\begin{array}{c}27.71^{* * *} \\
(10.13)\end{array}$ & $\begin{array}{l}471.3^{* * *} \\
(207.1)\end{array}$ \\
\hline Observations & 5,576 & 5,576 \\
\hline R-squared & 0.700 & 0.689 \\
\hline
\end{tabular}

Output 8 First stage on Education Including Wealth Score- One Instrument

\begin{tabular}{|c|c|c|}
\hline \multirow{2}{*}{$\begin{array}{l}\text { VARIABLES } \\
\text { Interacted Dummy }\end{array}$} & \multicolumn{2}{|c|}{$\begin{array}{c}\text { Education } \\
\text { (years) }\end{array}$} \\
\hline & $\begin{array}{c}1.743^{* * * *} \\
(0.216)\end{array}$ & $\begin{array}{c}1.630^{* * * *} \\
(0.209)\end{array}$ \\
\hline Exposition Dummy & $\begin{array}{c}-6.391^{* * * *} \cdot k^{2} \\
(0.188)\end{array}$ & 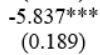 \\
\hline Wealth Score & $\begin{array}{c}1.846^{* * \cdots \cdot k} \\
(0.0889)\end{array}$ & 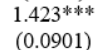 \\
\hline Sex $($ Male $=1)$ & $\begin{array}{l}0.948^{* * \cdots k} \\
(0.176)\end{array}$ & $\begin{array}{c}0.754^{* * * k} \\
(0.179)\end{array}$ \\
\hline Age & $\begin{array}{l}-0.974 \\
(0.621)\end{array}$ & $\begin{array}{l}-1.160^{*} \\
(0.613)\end{array}$ \\
\hline $\mathrm{Age}^{2}$ & $\begin{array}{c}0.0106 \\
(0.00694)\end{array}$ & $\begin{array}{c}0.0126^{*} \\
(0.00686)\end{array}$ \\
\hline $\begin{array}{l}\text { Occupation } \\
\text { Base }=\text { Employed }\end{array}$ & & \\
\hline Unemployed & & $\begin{array}{l}0.728^{* *} \cdot \\
(0.293)\end{array}$ \\
\hline Inactive & & $\begin{array}{c}-0.432^{* * * * *} \\
(0.108)\end{array}$ \\
\hline $\begin{array}{l}\text { Social Security Regime } \\
\text { Base=Contributive }\end{array}$ & & \\
\hline Subsidized Regime & & $\begin{array}{c}-1.346^{* * * *} * \\
(0.126)\end{array}$ \\
\hline Special Regime & & $\begin{array}{c}0.347 \\
(0.293)\end{array}$ \\
\hline Not Affiliated & & $\begin{array}{c}-0.934^{\text {*水* }} \\
(0.167)\end{array}$ \\
\hline Owns Motorcycle & & $\begin{array}{c}0.104 \\
(0.108)\end{array}$ \\
\hline Owns Vehicle & & $\begin{array}{c}0.577^{*} \text { *k* } \\
(0.148)\end{array}$ \\
\hline Constant & $\begin{array}{c}31.14^{\text {*k } k_{k}} \\
(11.30)\end{array}$ & 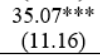 \\
\hline Observations & 5,592 & 5,576 \\
\hline R-squared & 0.537 & 0.563 \\
\hline
\end{tabular}


Output 9 First Stage on Education Including Wealth Score- Several Instruments

\begin{tabular}{|c|c|c|c|c|}
\hline VARIABLES & $\begin{array}{c}\text { Education } \\
\text { (years) }\end{array}$ & Education $^{2}$ & $\begin{array}{c}\text { Education } \\
\text { (years) }\end{array}$ & Education ${ }^{2}$ \\
\hline Interacted Dummy 1 & $\begin{array}{l}3.356^{* *} \\
(1.354)\end{array}$ & $\begin{array}{l}47.19^{* * *} \\
(23.32)\end{array}$ & $\begin{array}{l}2.807^{* *} \\
(1.431)\end{array}$ & $\begin{array}{l}35.76 \\
(25.04)\end{array}$ \\
\hline Interacted Dummy 2 & $\begin{array}{c}1.331 * * * \\
(0.372)\end{array}$ & $\begin{array}{c}23.69 * * * \\
(8.267)\end{array}$ & $\begin{array}{c}1.220 * * * \\
(0.359)\end{array}$ & $\begin{array}{c}21.78^{* * *} \\
(8.129)\end{array}$ \\
\hline Interacted Dummy 3 & $\begin{array}{c}1.357^{* * * *} \\
(0.316)\end{array}$ & $\begin{array}{c}27.46^{* * *} \\
(7.605)\end{array}$ & $\begin{array}{c}1.264 * * * \\
(0.308)\end{array}$ & $\begin{array}{c}25.69^{* * *} \\
(7.466)\end{array}$ \\
\hline Education of the moth & & & & \\
\hline None & $\begin{array}{c}-12.14 * * * \\
(0.774)\end{array}$ & $\begin{array}{c}-226.1^{* * *} \\
(15.03)\end{array}$ & $\begin{array}{c}-11.49 * * * \\
(0.853)\end{array}$ & $\begin{array}{c}-212.2^{* * * *} \\
(16.85)\end{array}$ \\
\hline Primary Schooling & $\begin{array}{c}-9.919 * * * \\
(0.287)\end{array}$ & $\begin{array}{c}-190.5^{* * *} \\
(6.751)\end{array}$ & $\begin{array}{c}-9.316^{* * * *} \\
(0.293)\end{array}$ & $\begin{array}{c}-179.2^{* * * *} \\
(6.885)\end{array}$ \\
\hline Secondary Schooling & $\begin{array}{c}-5.464^{* * *} \\
(0.277)\end{array}$ & $\begin{array}{c}-129.2^{* * * *} \\
(6.616)\end{array}$ & $\begin{array}{l}-5.121^{* * *} \\
(0.275)\end{array}$ & $\begin{array}{c}-122.6^{* * * *} \\
(6.561)\end{array}$ \\
\hline Wealth Score & $\begin{array}{c}0.840^{* * * *} \\
(0.111)\end{array}$ & $\begin{array}{c}15.15^{* * *} \\
(2.018)\end{array}$ & $\begin{array}{l}0.577^{* * * *} \\
(0.109)\end{array}$ & $\begin{array}{c}10.30^{* * * *} \\
(2.000)\end{array}$ \\
\hline $\operatorname{Sex}($ Male $=1)$ & $\begin{array}{c}3.069^{* * * *} \\
(0.393)\end{array}$ & $\begin{array}{c}58.14^{* * * *} \\
(7.564)\end{array}$ & $\begin{array}{c}3.103 * * * \\
(0.368)\end{array}$ & $\begin{array}{c}58.80^{* * * *} \\
(7.207)\end{array}$ \\
\hline Age & $\begin{array}{c}0.756 \\
(0.793)\end{array}$ & $\begin{array}{l}35.19^{* *} \\
(17.71)\end{array}$ & $\begin{array}{c}0.468 \\
(0.784)\end{array}$ & $\begin{array}{l}29.90^{*} \\
(17.50)\end{array}$ \\
\hline Age $^{2}$ & $\begin{array}{l}-0.00856 \\
(0.00889)\end{array}$ & $\begin{array}{c}-0.393^{* *} \\
(0.199)\end{array}$ & $\begin{array}{l}-0.00534 \\
(0.00880)\end{array}$ & $\begin{array}{l}-0.334^{*} \\
(0.197)\end{array}$ \\
\hline $\begin{array}{l}\text { Occupation } \\
\text { Base=Employed }\end{array}$ & & & & \\
\hline Unemployed & $\begin{array}{c}0.436 \\
(0.348)\end{array}$ & $\begin{array}{c}3.522 \\
(7.963)\end{array}$ & $\begin{array}{l}0.560^{*} \\
(0.340)\end{array}$ & $\begin{array}{c}5.804 \\
(7.775)\end{array}$ \\
\hline Inactive & $\begin{array}{c}-0.00306 \\
(0.129)\end{array}$ & $\begin{array}{l}-1.030 \\
(2.604)\end{array}$ & $\begin{array}{l}0.0802 \\
(0.126)\end{array}$ & $\begin{array}{l}0.557 \\
(2.564)\end{array}$ \\
\hline $\begin{array}{l}\text { Social Security Regim } \\
\text { Base }=\text { Contributive }\end{array}$ & & & & \\
\hline Subsidized Regime & & & $\begin{array}{c}-1.000^{* * * *} \\
(0.152)\end{array}$ & $\begin{array}{c}-18.26^{* * * *} \\
(2.807)\end{array}$ \\
\hline Special Regime & & & $\begin{array}{c}0.586 \\
(0.384)\end{array}$ & $\begin{array}{l}14.81 \\
(9.030)\end{array}$ \\
\hline Not Affiliated & & & $\begin{array}{c}-0.747^{* * *} \\
(0.266)\end{array}$ & $\begin{array}{c}-15.18^{* * * *} \\
(5.065)\end{array}$ \\
\hline Owns Refrigerator & & & $\begin{array}{c}0.522^{* * *} \\
(0.175)\end{array}$ & $\begin{array}{c}10.05^{* * * *} \\
(3.290)\end{array}$ \\
\hline Constant & $\begin{array}{l}-0.0117 \\
(14.40)\end{array}$ & $\begin{array}{l}-442.9 \\
(321.4)\end{array}$ & $\begin{array}{c}5.100 \\
(14.27)\end{array}$ & $\begin{array}{l}-349.5 \\
(318.0)\end{array}$ \\
\hline Observations & 2,039 & 2,039 & 2,032 & 2,032 \\
\hline R-squared & 0.782 & 0.765 & 0.794 & 0.775 \\
\hline
\end{tabular}

Output 10 Ologit First Stage on Education- One Instrument

\begin{tabular}{|c|c|}
\hline VARIABLES & $\begin{array}{c}\text { Education } \\
\text { (years) }\end{array}$ \\
\hline Interacted Dummy & $\begin{array}{c}1.097 * * * \\
(0.157)\end{array}$ \\
\hline Exposition Dummy & $\begin{array}{c}-5.006 * * * \\
(0.184)\end{array}$ \\
\hline Sex $($ Male $=1)$ & $\begin{array}{c}0.713 * * * \\
(0.138)\end{array}$ \\
\hline Age & $\begin{array}{l}-0.696^{*} \\
(0.422)\end{array}$ \\
\hline $\mathrm{Age}^{2}$ & $\begin{array}{l}0.00778 * \\
(0.00471)\end{array}$ \\
\hline $\begin{array}{l}\text { Occupation } \\
\text { Base = Employed }\end{array}$ & \\
\hline Unemployed & $\begin{array}{c}0.571 * * * \\
(0.192)\end{array}$ \\
\hline Inactive & $\begin{array}{c}-0.320 * * * \\
(0.0679)\end{array}$ \\
\hline $\begin{array}{l}\text { Social Security Regime } \\
\text { Base }=\text { Contributive }\end{array}$ & \\
\hline Subsidized Regime & $\begin{array}{c}-1.063^{* * *} * \\
(0.0787)\end{array}$ \\
\hline Special Regime & $\begin{array}{c}0.550^{* *} \\
(0.233)\end{array}$ \\
\hline Not Affiliated & $\begin{array}{c}-0.740 * * * \\
(0.110)\end{array}$ \\
\hline Owns Motorcycle & $\begin{array}{l}0.153 * * \\
(0.0721)\end{array}$ \\
\hline Owns Vehicle & $\begin{array}{c}0.790^{* * *} \\
(0.109)\end{array}$ \\
\hline Observations & 5,576 \\
\hline
\end{tabular}


Output 11 Short Regression on Physical Activity Variables- One Instrument

\begin{tabular}{|c|c|c|c|}
\hline \multirow[b]{2}{*}{ VARIABLES } & \multicolumn{3}{|c|}{ Physical Activity (min/week) } \\
\hline & Transport & Leisure & Total \\
\hline \multirow[t]{2}{*}{ Interacted Dummy } & 33.84 & 13.31 & 47.15 \\
\hline & $(21.58)$ & $(20.82)$ & $(37.35)$ \\
\hline \multirow[t]{2}{*}{ Exposition Dummy } & -23.11 & -27.76 & -50.87 \\
\hline & $(18.23)$ & $(17.23)$ & $(32.17)$ \\
\hline \multirow{2}{*}{ Sex $($ Male $=1)$} & $90.89^{* * * *}$ & $100.3^{*} \mathrm{k}^{2} \mathrm{k}$ & $191.2^{\text {**** }}$ \\
\hline & $(12.69)$ & $(13.28)$ & $(24.18)$ \\
\hline \multirow[t]{2}{*}{ Age } & $160.6^{* * * * *}$ & -7.441 & $153.1^{*}$ \\
\hline & $(61.19)$ & $(50.88)$ & $(92.54)$ \\
\hline $\mathrm{Age}^{2}$ & $\begin{array}{c}-1.794^{* * * *} * \\
(0.687)\end{array}$ & $\begin{array}{l}0.0911 \\
(0.570)\end{array}$ & $\begin{array}{l}-1.703 \\
(1.037)\end{array}$ \\
\hline \multicolumn{4}{|l|}{$\begin{array}{l}\text { Occupation } \\
\text { Base }=\text { Employed }\end{array}$} \\
\hline Unemployed & $\begin{array}{l}-10.85 \\
(24.17)\end{array}$ & $\begin{array}{c}13.23 \\
(21.29)\end{array}$ & $\begin{array}{c}2.379 \\
(38.10)\end{array}$ \\
\hline Inactive & $\begin{array}{c}-35.74^{* * * *} \\
(9.493)\end{array}$ & $\begin{array}{l}1.506 \\
(6.715)\end{array}$ & $\begin{array}{c}-34.24^{* * *} \\
(13.44)\end{array}$ \\
\hline \multicolumn{4}{|c|}{$\begin{array}{l}\text { Social Security Regime } \\
\text { Base=Contributive }\end{array}$} \\
\hline Subsidized Regime & $\begin{array}{c}46.67 * * * * \\
(10.52)\end{array}$ & $\begin{array}{l}-4.703 \\
(7.313)\end{array}$ & $\begin{array}{l}41.97^{* *} \\
(16.42)\end{array}$ \\
\hline Special Regime & $\begin{array}{l}-5.693 \\
(26.52)\end{array}$ & $\begin{array}{l}40.28^{* * *} \\
(19.77)\end{array}$ & $\begin{array}{c}34.59 \\
(32.26)\end{array}$ \\
\hline Not Affiliated & $\begin{array}{c}59.99 * * * \\
(13.97)\end{array}$ & $\begin{array}{c}0.887 \\
(10.78)\end{array}$ & $\begin{array}{l}60.88^{* * *} \\
(24.23)\end{array}$ \\
\hline Owns Motorcycle & $\begin{array}{l}-15.41 \\
(11.24)\end{array}$ & $\begin{array}{l}3.489 \\
(9.344)\end{array}$ & $\begin{array}{l}-11.92 \\
(15.42)\end{array}$ \\
\hline Owns Vehicle & $\begin{array}{l}-80.33^{* *_{*} * k} \\
(12.75)\end{array}$ & $\begin{array}{l}21.76^{*} \\
(11.30)\end{array}$ & $\begin{array}{l}-58.58^{* * * *} \\
(19.78)\end{array}$ \\
\hline Constant & $\begin{array}{c}-2,781^{* * *} \\
(1,114)\end{array}$ & $\begin{array}{l}215.6 \\
(925.7)\end{array}$ & $\begin{array}{l}-2,566 \\
(1,677)\end{array}$ \\
\hline Observations & 5,732 & 5,732 & 5,732 \\
\hline R-squared & 0.134 & 0.101 & 0.141 \\
\hline
\end{tabular}

Output 12 Short Regression on Physical Activity Variables- Several Instruments

\begin{tabular}{|c|c|c|c|}
\hline \multirow[b]{2}{*}{ VARIABLES } & \multicolumn{3}{|c|}{ Physical Activity ( $\mathrm{min} / \mathrm{week}$ ) } \\
\hline & Transport & Leisure & Total \\
\hline \multirow[t]{2}{*}{ Interacted Dummy 1} & -47.59 & 22.14 & -25.46 \\
\hline & $(58.15)$ & $(38.31)$ & $(73.27)$ \\
\hline \multirow[t]{2}{*}{ Interacted Dummy 2} & 17.75 & 27.78 & 45.53 \\
\hline & $(34.24)$ & $(23.22)$ & $(42.47)$ \\
\hline \multirow[t]{2}{*}{ Interacted Dummy 3} & 42.35 & 0.274 & 42.63 \\
\hline & $(31.63)$ & $(21.65)$ & \\
\hline \multicolumn{4}{|l|}{ Education of the mother } \\
\hline None & $\begin{array}{l}-49.30 \\
(45.19)\end{array}$ & $\begin{array}{c}-56.85^{* *} \\
(24.58)\end{array}$ & $\begin{array}{c}-106.1 * * \\
(52.92)\end{array}$ \\
\hline Primary Schooling & $\begin{array}{l}-30.82 \\
(28.96)\end{array}$ & $\begin{array}{c}-46.41^{* * * *} \\
(17.99)\end{array}$ & $\begin{array}{c}-77.23^{* *} \\
(34.88)\end{array}$ \\
\hline Secondary Schooling & $\begin{array}{l}-21.14 \\
(27.80)\end{array}$ & $\begin{array}{l}-15.23 \\
(17.82)\end{array}$ & $\begin{array}{l}-36.37 \\
(33.94)\end{array}$ \\
\hline Sex (Male $=1)$ & $\begin{array}{c}104.8^{* * *} \\
(20.10)\end{array}$ & $\begin{array}{c}105.8^{* * *} \\
(13.63)\end{array}$ & $\begin{array}{c}210.6^{* * *} \\
(25.43)\end{array}$ \\
\hline Age & $\begin{array}{l}167.3^{* * *} \\
(71.86)\end{array}$ & $\begin{array}{l}-5.917 \\
(50.71)\end{array}$ & $\begin{array}{l}161.4^{*} \\
(92.22)\end{array}$ \\
\hline Age $^{2}$ & $\begin{array}{l}-1.867^{* *} \\
(0.806)\end{array}$ & $\begin{array}{l}0.0777 \\
(0.568)\end{array}$ & $\begin{array}{l}-1.789^{*} \\
(1.034)\end{array}$ \\
\hline \multicolumn{4}{|l|}{ Occupation } \\
\hline $\begin{array}{l}\text { Dase- imployea } \\
\text { Unemployed }\end{array}$ & $\begin{array}{l}-13.50 \\
(32.21)\end{array}$ & $\begin{array}{c}12.91 \\
(21.16)\end{array}$ & $\begin{array}{l}-0.589 \\
(38.01)\end{array}$ \\
\hline Inactive & $\begin{array}{c}-35.89^{* * *} \\
(11.06)\end{array}$ & $\begin{array}{l}1.704 \\
(6.718)\end{array}$ & $\begin{array}{c}-34.19^{* *} \\
(13.47)\end{array}$ \\
\hline \multicolumn{4}{|l|}{ Social Security Regime } \\
\hline Subsidized Regime & $\begin{array}{c}49.58^{* * *} \\
(14.73)\end{array}$ & $\begin{array}{l}-2.056 \\
(7.380)\end{array}$ & $\begin{array}{c}47.52^{* * * *} \\
(16.76)\end{array}$ \\
\hline Special Regime & $\begin{array}{l}-5.917 \\
(20.58)\end{array}$ & $\begin{array}{l}39.65^{* *} \\
(19.67)\end{array}$ & $\begin{array}{c}33.73 \\
(32.15)\end{array}$ \\
\hline \multirow[t]{2}{*}{ Not Affiliated } & $61.71^{* * *}$ & 1.448 & $63.15^{* * *}$ \\
\hline & $(21.35)$ & $(10.83)$ & $(24.32)$ \\
\hline \multirow[t]{2}{*}{ Owns Vehicle } & $-8327^{* * *}$ & $20.57^{*}$ & $\begin{array}{l}(15.46) \\
-62.69 * * *\end{array}$ \\
\hline & $(15.35)$ & $(11.35)$ & $(19.85)$ \\
\hline \multirow{2}{*}{ Constant } & $-2,907^{* *}$ & 184.7 & $-2,722$ \\
\hline & $(1,300)$ & $(922.4)$ & $(1,672)$ \\
\hline Observations & 5,732 & 5,732 & 5,732 \\
\hline R-squared & 0.137 & 0.103 & 0.144 \\
\hline
\end{tabular}


Output 13 Short Regression on Physical Activity Variables Including Wealth Score- One Instrument

\begin{tabular}{|c|c|c|c|c|c|c|}
\hline \multirow[b]{2}{*}{ VARIABLES } & \multicolumn{6}{|c|}{ Physical Activity (min/week) } \\
\hline & Transport & Leisure & Total & Transport & Leisure & Total \\
\hline \multirow[t]{2}{*}{ Interacted Dummy } & 33.46 & 15.50 & 48.96 & 33.05 & 13.75 & 46.80 \\
\hline & $(29.81)$ & $(20.48)$ & $(37.03)$ & $(29.59)$ & $(20.80)$ & $(37.35)$ \\
\hline Exposition Dummy & $\begin{array}{l}-10.26 \\
(26.14)\end{array}$ & $\begin{array}{l}-31.10^{*} \\
(17.64)\end{array}$ & $\begin{array}{l}-41.37 \\
(31.99)\end{array}$ & $\begin{array}{l}-25.98 \\
(26.32)\end{array}$ & $\begin{array}{l}-26.17 \\
(17.40)\end{array}$ & $\begin{array}{l}-52.14 \\
(32.29)\end{array}$ \\
\hline Wealth Score & $\begin{array}{c}-35.69 * * * \\
(9.768)\end{array}$ & $\begin{array}{l}12.18 * * \\
(5.556)\end{array}$ & $\begin{array}{c}-23.51^{* *} \\
(11.15)\end{array}$ & $\begin{array}{l}-15.32 \\
(10.78)\end{array}$ & $\begin{array}{l}8.506 \\
(5.838)\end{array}$ & $\begin{array}{l}-6.814 \\
(12.17)\end{array}$ \\
\hline Sex $($ Male $=1)$ & $\begin{array}{c}104.9 * * * * \\
(19.26)\end{array}$ & $\begin{array}{c}103.5 * * * \\
(12.83)\end{array}$ & $\begin{array}{c}208.4 * * * \\
(24.23)\end{array}$ & $\begin{array}{c}92.52^{* * * *} \\
(18.99)\end{array}$ & $\begin{array}{c}99.40 * * * \\
(13.30)\end{array}$ & $\begin{array}{c}191.9 * * * \\
(24.23)\end{array}$ \\
\hline Age & $\begin{array}{l}157.4^{* *} \\
(73.20)\end{array}$ & $\begin{array}{l}-3.753 \\
(50.53)\end{array}$ & $\begin{array}{l}153.6^{*} \\
(92.75)\end{array}$ & $\begin{array}{l}160.6^{* *} \\
(72.09)\end{array}$ & $\begin{array}{l}-7.472 \\
(50.91)\end{array}$ & $\begin{array}{l}153.2^{*} \\
(92.57)\end{array}$ \\
\hline $\mathrm{Age}^{2}$ & $\begin{array}{c}-1.759 * * \\
(0.821)\end{array}$ & $\begin{array}{l}0.0488 \\
(0.566)\end{array}$ & $\begin{array}{l}-1.710 \\
(1.040)\end{array}$ & $\begin{array}{c}-1.792^{* *} \\
(0.808)\end{array}$ & $\begin{array}{l}0.0904 \\
(0.570)\end{array}$ & $\begin{array}{l}-1.702 \\
(1.038)\end{array}$ \\
\hline \multicolumn{7}{|l|}{$\begin{array}{l}\text { Occupation } \\
\text { Base }=\text { Employed }\end{array}$} \\
\hline Unemployed & & & & $\begin{array}{l}-9.538 \\
(32.31)\end{array}$ & $\begin{array}{l}12.50 \\
(21.29)\end{array}$ & $\begin{array}{c}2.962 \\
(38.16)\end{array}$ \\
\hline Inactive & & & & $\begin{array}{c}-36.28 * * * \\
(11.09)\end{array}$ & $\begin{array}{l}1.803 \\
(6.729)\end{array}$ & $\begin{array}{c}-34.48^{* *} \\
(13.48)\end{array}$ \\
\hline \multicolumn{7}{|l|}{ Social Security Regime } \\
\hline Subsidized Regime & & & & $\begin{array}{c}42.38 * * * \\
(14.97)\end{array}$ & $\begin{array}{l}-2.323 \\
(7.338)\end{array}$ & $\begin{array}{l}40.06 * * \\
(16.92)\end{array}$ \\
\hline Special Regime & & & & $\begin{array}{l}-4.989 \\
(20.59)\end{array}$ & $\begin{array}{c}39.89 * * \\
(19.78)\end{array}$ & $\begin{array}{c}34.90 \\
(32.27)\end{array}$ \\
\hline Not Affiliated & & & & $\begin{array}{l}57.54 * * * \\
(21.42)\end{array}$ & $\begin{array}{l}2.250 \\
(10.87)\end{array}$ & $\begin{array}{l}59.79 * * \\
(24.43)\end{array}$ \\
\hline Owns Motorcycle & & & & $\begin{array}{l}-12.96 \\
(11.21)\end{array}$ & $\begin{array}{l}2.127 \\
(9.480)\end{array}$ & $\begin{array}{l}-10.83 \\
(15.61)\end{array}$ \\
\hline Owns Vehicle & & & & $\begin{array}{c}-75.46 * * * \\
(15.54)\end{array}$ & $\begin{array}{l}19.05 \\
(11.63)\end{array}$ & $\begin{array}{c}-56.41^{* * * *} \\
(20.18)\end{array}$ \\
\hline Constant & $\begin{array}{c}-2,720 * * \\
(1,324) \\
\end{array}$ & $\begin{array}{c}147.8 \\
(919.1) \\
\end{array}$ & $\begin{array}{c}-2,572 \\
(1,681) \\
\end{array}$ & $\begin{array}{c}-2,774 * * \\
(1,304)\end{array}$ & $\begin{array}{l}211.3 \\
(926.0) \\
\end{array}$ & $\begin{array}{l}-2,562 \\
(1,678) \\
\end{array}$ \\
\hline Observations & 5,749 & 5,749 & 5,749 & 5,732 & 5,732 & 5,732 \\
\hline$R$-squared & 0.123 & 0.100 & 0.135 & 0.135 & 0.101 & 0.141 \\
\hline
\end{tabular}

Output 14 Short Regression on Physical Activity Variables Including Wealth Score-Several Instrument

\begin{tabular}{|c|c|c|c|c|c|c|}
\hline \multirow[b]{2}{*}{ VARIABLES } & \multicolumn{6}{|c|}{ Physical Activity (min/week) } \\
\hline & Transport & Leisure & Total & Transport & Leisure & Total \\
\hline Interacted Dummy 1 & $\begin{array}{l}-50.08 \\
(57.53)\end{array}$ & $\begin{array}{c}33.75 \\
(38.43)\end{array}$ & $\begin{array}{l}-16.33 \\
(72.32)\end{array}$ & $\begin{array}{l}-50.66 \\
(58.02)\end{array}$ & $\begin{array}{c}22.94 \\
(38.09)\end{array}$ & $\begin{array}{l}-27.72 \\
(72.80)\end{array}$ \\
\hline Interacted Dummy 2 & $\begin{array}{c}22.37 \\
(34.78)\end{array}$ & $\begin{array}{l}28.27 \\
(22.69)\end{array}$ & $\begin{array}{c}50.65 \\
(42.39)\end{array}$ & $\begin{array}{l}16.59 \\
(34.28)\end{array}$ & $\begin{array}{l}28.08 \\
(23.21)\end{array}$ & $\begin{array}{c}44.68 \\
(42.49)\end{array}$ \\
\hline Interacted Dummy 3 & $\begin{array}{c}38.97 \\
(31.84)\end{array}$ & $\begin{array}{l}2.706 \\
(21.46)\end{array}$ & $\begin{array}{c}41.67 \\
(39.48)\end{array}$ & $\begin{array}{c}40.32 \\
(31.69)\end{array}$ & $\begin{array}{l}0.803 \\
(21.63)\end{array}$ & $\begin{array}{c}41.12 \\
(39.77)\end{array}$ \\
\hline Education of the moth & & & & & & \\
\hline None & $\begin{array}{l}-39.51 \\
(45.16)\end{array}$ & $\begin{array}{c}-61.16^{* *} \\
(25.19)\end{array}$ & $\begin{array}{l}-100.7 * \\
(53.49)\end{array}$ & $\begin{array}{l}-60.82 \\
(45.79)\end{array}$ & $\begin{array}{c}-53.85^{* *} \\
(25.23)\end{array}$ & $\begin{array}{c}-114.7 * * \\
(53.93)\end{array}$ \\
\hline Primary Schooling & $\begin{array}{l}-19.13 \\
(29.04)\end{array}$ & $\begin{array}{c}-48.23 * * * \\
(18.34)\end{array}$ & $\begin{array}{l}-67.37^{*} \\
(34.95)\end{array}$ & $\begin{array}{l}-37.89 \\
(29.17)\end{array}$ & $\begin{array}{c}-44.57 * * \\
(18.33)\end{array}$ & $\begin{array}{c}-82.47 * * \\
(35.29)\end{array}$ \\
\hline Secondary Schooling & $\begin{array}{l}-7.852 \\
(27.57)\end{array}$ & $\begin{array}{l}-19.27 \\
(18.29)\end{array}$ & $\begin{array}{l}-27.12 \\
(33.73)\end{array}$ & $\begin{array}{l}-23.35 \\
(27.79)\end{array}$ & $\begin{array}{l}-14.65 \\
(17.87)\end{array}$ & $\begin{array}{l}-38.01 \\
(33.94)\end{array}$ \\
\hline Wealth Score & $\begin{array}{c}-41.57 * * * \\
(10.26)\end{array}$ & $\begin{array}{l}9.015 \\
(5.617)\end{array}$ & $\begin{array}{c}-32.56 * * * \\
(11.71)\end{array}$ & $\begin{array}{l}-21.58^{*} \\
(11.05)\end{array}$ & $\begin{array}{l}5.616 \\
(5.833)\end{array}$ & $\begin{array}{l}-15.96 \\
(12.53)\end{array}$ \\
\hline Sex $($ Male $=1)$ & $\begin{array}{c}118.6 * * * \\
(20.48)\end{array}$ & $\begin{array}{c}108.5 * * * \\
(13.25)\end{array}$ & $\begin{array}{c}227.0 * * * \\
(25.51)\end{array}$ & $\begin{array}{c}109.0 * * * \\
(20.26)\end{array}$ & $\begin{array}{c}104.7 * * * \\
(13.70)\end{array}$ & $\begin{array}{c}213.7 * * * \\
(25.61)\end{array}$ \\
\hline Age & $\begin{array}{l}163.8 * * \\
(73.11)\end{array}$ & $\begin{array}{l}-2.604 \\
(50.40)\end{array}$ & $\begin{array}{l}161.2^{*} \\
(92.48)\end{array}$ & $\begin{array}{l}168.1 * * \\
(71.96)\end{array}$ & $\begin{array}{l}-6.132 \\
(50.75)\end{array}$ & $\begin{array}{l}162.0^{*} \\
(92.25)\end{array}$ \\
\hline $\mathrm{Age}^{2}$ & $\begin{array}{c}-1.829 * * \\
(0.820)\end{array}$ & $\begin{array}{l}0.0396 \\
(0.564)\end{array}$ & $\begin{array}{l}-1.789 * \\
(1.037)\end{array}$ & $\begin{array}{c}-1.873^{* *} \\
(0.807)\end{array}$ & $\begin{array}{l}0.0793 \\
(0.569)\end{array}$ & $\begin{array}{l}-1.794^{*} \\
(1.034)\end{array}$ \\
\hline $\begin{array}{l}\text { Occupation } \\
\text { Base =Employed }\end{array}$ & & & & & & \\
\hline Unemployed & & & & $\begin{array}{l}-11.91 \\
(32.28)\end{array}$ & $\begin{array}{l}12.49 \\
(21.17)\end{array}$ & $\begin{array}{c}0.589 \\
(38.07)\end{array}$ \\
\hline Inactive & & & & $\begin{array}{c}-36.62 * * * \\
(11.11)\end{array}$ & $\begin{array}{c}1.893 \\
(6.727)\end{array}$ & $\begin{array}{c}-34.72 * * \\
(13.51)\end{array}$ \\
\hline $\begin{array}{l}\text { Social Security Regim } \\
\text { Base=Contributive }\end{array}$ & & & & & & \\
\hline Subsidized Regime & & & & $\begin{array}{c}44.16 * * * \\
(15.17)\end{array}$ & $\begin{array}{l}-0.648 \\
(7.369)\end{array}$ & $\begin{array}{l}43.52 * * \\
(17.11)\end{array}$ \\
\hline Special Regime & & & & $\begin{array}{l}-5.030 \\
(20.58)\end{array}$ & $\begin{array}{c}39.41^{* *} \\
(19.68)\end{array}$ & $\begin{array}{c}34.38 \\
(32.15)\end{array}$ \\
\hline Not Affiliated & & & & $\begin{array}{l}58.49 * * * \\
(21.45)\end{array}$ & $\begin{array}{l}2.286 \\
(10.88)\end{array}$ & $\begin{array}{l}60.77 * * \\
(24.46)\end{array}$ \\
\hline Owns Motorcycle & & & & $\begin{array}{l}-14.05 \\
(11.17)\end{array}$ & $\begin{array}{l}2.300 \\
(9.508)\end{array}$ & $\begin{array}{l}-11.75 \\
(15.62)\end{array}$ \\
\hline Owns Vehicle & & & & $\begin{array}{c}-76.83 * * * \\
(15.59)\end{array}$ & $\begin{array}{l}18.90 \\
(11.64)\end{array}$ & $\begin{array}{c}-57.93 * * * \\
(20.26)\end{array}$ \\
\hline Constant & $\begin{array}{c}-2,838 * * \\
(1,323)\end{array}$ & $\begin{array}{l}126.3 \\
(916.7) \\
\end{array}$ & $\begin{array}{c}-2,712 \\
(1,676) \\
\end{array}$ & $\begin{array}{c}-2,911 * * \\
(1,302)\end{array}$ & $\begin{array}{l}185.7 \\
(923.0)\end{array}$ & $\begin{array}{l}-2,725 \\
(1,672) \\
\end{array}$ \\
\hline Observations & 5,749 & 5,749 & 5,749 & 5,732 & 5,732 & 5,732 \\
\hline R-squared & 0.125 & 0.102 & 0.138 & 0.138 & 0.103 & 0.144 \\
\hline
\end{tabular}


Output 15 Short Regression on Physical Activity using an ologit first stage

\begin{tabular}{|c|c|c|c|c|c|c|}
\hline \multirow[b]{2}{*}{ VARIABLES } & \multicolumn{6}{|c|}{ Physical Activity (min/week) } \\
\hline & Transport & Leisure & Total & Transport & Leisure & Total \\
\hline \multirow{2}{*}{ Education (ologit fitted values) } & 0.671 & $4.555^{* *}$ & 5.227 & 1.466 & $4.137^{* *}$ & 5.603 \\
\hline & (3.295) & $(1.998)$ & $(3.967)$ & (3.338) & $(2.045)$ & $(4.031)$ \\
\hline \multirow[t]{2}{*}{ Wealth Score } & & & & -15.85 & 8.350 & -7.503 \\
\hline & & & & $(10.77)$ & $(5.874)$ & (12.17) \\
\hline \multirow{2}{*}{ Sex $($ Male $=1)$} & $91.95^{* * *}$ & $97.45^{* * *}$ & $189.4^{* * *}$ & $92.99 * * *$ & $96.90^{* * *}$ & $189.9^{* * *}$ \\
\hline & $(18.32)$ & (13.13) & (23.49) & $(18.33)$ & (13.15) & $(23.50)$ \\
\hline \multirow[t]{2}{*}{ Age } & $162.4^{* *}$ & -3.916 & $158.5^{*}$ & $163.0^{* *}$ & -4.200 & $158.8^{*}$ \\
\hline & $(72.06)$ & $(50.94)$ & $(92.68)$ & (72.14) & $(50.99)$ & $(92.70)$ \\
\hline \multirow[t]{2}{*}{$\mathrm{Age}^{2}$} & $-1.823^{* *}$ & 0.0496 & $-1.773^{*}$ & $-1.827^{* *}$ & 0.0516 & $-1.775^{*}$ \\
\hline & $(0.808)$ & $(0.571)$ & $(1.039)$ & $(0.810)$ & $(0.571)$ & $(1.039)$ \\
\hline \multicolumn{7}{|l|}{ Occupation } \\
\hline \multicolumn{7}{|l|}{ Base $=$ Employed } \\
\hline \multirow[t]{2}{*}{ Unemployed } & -10.93 & 10.70 & -0.224 & -10.04 & 10.24 & 0.196 \\
\hline & (32.36) & (21.10) & $(38.07)$ & (32.41) & $(21.08)$ & (38.11) \\
\hline Inactive & $\begin{array}{l}-35.60^{* * *} \\
(11.27)\end{array}$ & $\begin{array}{c}2.945 \\
(6.800)\end{array}$ & $\begin{array}{c}-32.65^{* *} \\
(13.68)\end{array}$ & $\begin{array}{l}-35.89 * * * \\
(11.29)\end{array}$ & 3.102 & $-32.79^{* *}$ \\
\hline \multirow{2}{*}{\multicolumn{7}{|c|}{$\begin{array}{l}\text { Social Security Regime } \\
\text { Base=Contributive }\end{array}$}} \\
\hline & & & & & & \\
\hline Subsidized Regime & $\begin{array}{c}47.76^{* * * *} \\
(15.46)\end{array}$ & $\begin{array}{c}0.233 \\
(8.192)\end{array}$ & $\begin{array}{c}48.00^{* * * *} \\
(17.80)\end{array}$ & $\begin{array}{c}44.15^{* * *} \\
(15.88)\end{array}$ & $\begin{array}{c}2.135 \\
(8.146)\end{array}$ & $\begin{array}{c}46.29 * * \\
(18.10)\end{array}$ \\
\hline Special Regime & $\begin{array}{c}-4.105 \\
(20.60)\end{array}$ & $\begin{array}{l}38.26^{*} \\
(19.81)\end{array}$ & $\begin{array}{c}34.16 \\
(32.32)\end{array}$ & $\begin{array}{l}-3.913 \\
(20.60)\end{array}$ & $\begin{array}{l}38.16^{*} \\
(19.82)\end{array}$ & $\begin{array}{c}34.25 \\
(32.32)\end{array}$ \\
\hline Not Affiliated & $\begin{array}{c}60.93 * * * \\
(21.85)\end{array}$ & $\begin{array}{c}4.367 \\
(10.87)\end{array}$ & $\begin{array}{c}65.30^{* * * *} \\
(24.78)\end{array}$ & $\begin{array}{c}58.95^{* * *} \\
(21.94)\end{array}$ & $\begin{array}{c}5.407 \\
(10.91)\end{array}$ & $\begin{array}{c}64.36^{* * *} \\
(24.91)\end{array}$ \\
\hline Owns Motorcycle & $\begin{array}{l}-16.35 \\
(11.13)\end{array}$ & $\begin{array}{c}2.583 \\
(9.081)\end{array}$ & $\begin{array}{l}-13.77 \\
(15.26)\end{array}$ & $\begin{array}{l}-13.89 \\
(11.24)\end{array}$ & $\begin{array}{c}1.288 \\
(9.227)\end{array}$ & $\begin{array}{l}-12.60 \\
(15.46)\end{array}$ \\
\hline Owns Vehicle & $\begin{array}{c}-81.02 * * * \\
(15.72)\end{array}$ & $\begin{array}{c}18.12 \\
(11.23)\end{array}$ & $\begin{array}{c}-62.90^{* * * *} \\
(20.06)\end{array}$ & $\begin{array}{c}-76.59 * * * \\
(15.88)\end{array}$ & $\begin{array}{c}15.79 \\
(11.52)\end{array}$ & $\begin{array}{c}-60.81^{* * * *} \\
(20.37)\end{array}$ \\
\hline Constant & $\begin{array}{c}-2,793^{* *} \\
(1,305)\end{array}$ & $\begin{array}{c}212.1 \\
(925.8)\end{array}$ & $\begin{array}{l}-2,581 \\
(1,681)\end{array}$ & $\begin{array}{c}-2,784^{* *} \\
(1,308)\end{array}$ & $\begin{array}{c}207.7 \\
(926.1)\end{array}$ & $\begin{array}{l}-2,577 \\
(1,682)\end{array}$ \\
\hline Observations & 5,732 & 5,732 & 5,732 & 5,732 & 5,732 & 5,732 \\
\hline R-squared & 0.134 & 0.101 & 0.140 & 0.134 & 0.101 & 0.141 \\
\hline
\end{tabular}

\section{Appendix C Complete Regression Outputs- Consumption Habits}

Output 16 OLS Results on the Consumption Variable

\begin{tabular}{|c|c|c|}
\hline \multirow{2}{*}{$\begin{array}{l}\text { VARIABLES } \\
\text { Education (years) }\end{array}$} & \multicolumn{2}{|c|}{ Fruits and Vegetables (servings/day) } \\
\hline & $\begin{array}{c}0.0853^{* * *} \\
(0.0115)\end{array}$ & $\begin{array}{c}0.0199 \\
(0.0405)\end{array}$ \\
\hline Education $^{2}$ & & $\begin{array}{c}0.00339 \\
(0.00212)\end{array}$ \\
\hline $\operatorname{Sex}($ Male $=1)$ & $\begin{array}{c}-0.277^{* * *} \\
(0.0959)\end{array}$ & $\begin{array}{c}-0.274^{* * *} \\
(0.0957)\end{array}$ \\
\hline Age & $\begin{array}{c}0.301 \\
(0.667)\end{array}$ & $\begin{array}{c}0.269 \\
(0.666)\end{array}$ \\
\hline $\mathrm{Age}^{2}$ & $\begin{array}{l}-0.00396 \\
(0.00738)\end{array}$ & $\begin{array}{l}-0.00361 \\
(0.00737)\end{array}$ \\
\hline \multicolumn{3}{|l|}{ Social Security } \\
\hline Subsidized Regime & $\begin{array}{c}-0.257^{* *} \\
(0.103)\end{array}$ & $\begin{array}{c}-0.256^{* *} \\
(0.103)\end{array}$ \\
\hline Special Regime & $\begin{array}{l}0.0735 \\
(0.209)\end{array}$ & $\begin{array}{l}0.0750 \\
(0.209)\end{array}$ \\
\hline Not Affiliated & $\begin{array}{c}-0.317^{* *} \\
(0.143)\end{array}$ & $\begin{array}{c}-0.305^{* *} \\
(0.143)\end{array}$ \\
\hline \multicolumn{3}{|l|}{ Occupation } \\
\hline $\begin{array}{l}\text { Base }=\text { Employed } \\
\text { Unemployed }\end{array}$ & $\begin{array}{l}-0.235 \\
(0.274)\end{array}$ & $\begin{array}{l}-0.236 \\
(0.272)\end{array}$ \\
\hline Inactive & $\begin{array}{l}0.0694 \\
(0.105)\end{array}$ & $\begin{array}{l}0.0788 \\
(0.105)\end{array}$ \\
\hline Owns Refrigerator & $\begin{array}{c}0.346^{* * * *} \\
(0.126)\end{array}$ & $\begin{array}{c}0.348^{* * * *} \\
(0.125)\end{array}$ \\
\hline Constant & $\begin{array}{l}-3.461 \\
(12.22) \\
\end{array}$ & $\begin{array}{l}-2.618 \\
(12.20) \\
\end{array}$ \\
\hline Observations & 2,875 & 2,875 \\
\hline R-squared & 0.198 & 0.199 \\
\hline
\end{tabular}


Output 17 2SLS Results on the Consumption Variable- One Instrument (left) and Several Instruments (right)

\begin{tabular}{|c|c|}
\hline VARIABLES & $\begin{array}{c}\text { Fruits and Vegetables } \\
\text { (servings/day) }\end{array}$ \\
\hline Education (years) & $\begin{array}{l}0.0178 \\
(0.141)\end{array}$ \\
\hline Exposition & $\begin{array}{l}-0.551 \\
(0.750)\end{array}$ \\
\hline $\operatorname{Sex}($ Male $=1)$ & $\begin{array}{l}0.0771 \\
(0.287)\end{array}$ \\
\hline Age & $\begin{array}{c}0.120 \\
(0.723)\end{array}$ \\
\hline $\mathrm{Age}^{2}$ & $\begin{array}{l}-0.00157 \\
(0.00812)\end{array}$ \\
\hline $\begin{array}{l}\text { Social Security } \\
\text { Base }=\text { Contributive }\end{array}$ & \\
\hline Subsidized Regime & $\begin{array}{c}-0.339 \\
(0.287)\end{array}$ \\
\hline Special Regime & $\begin{array}{l}0.0867 \\
(0.327)\end{array}$ \\
\hline Not Affiliated & $\begin{array}{l}-0.325 \\
(0.243)\end{array}$ \\
\hline $\begin{array}{l}\text { Occupation } \\
\text { Base }=\text { Employed }\end{array}$ & \\
\hline Unemployed & $\begin{array}{l}-0.621^{*} \\
(0.350)\end{array}$ \\
\hline Inactive & $\begin{array}{c}0.108 \\
(0.125)\end{array}$ \\
\hline Owns Refrigerator & $\begin{array}{l}0.636^{* *} \\
(0.264)\end{array}$ \\
\hline Constant & $\begin{array}{l}0.0863 \\
(12.73)\end{array}$ \\
\hline Observations & 1,715 \\
\hline R-squared & 0.255 \\
\hline
\end{tabular}

\begin{tabular}{|c|c|}
\hline VARIABLES & $\begin{array}{c}\text { Fruits and Vegetables } \\
\text { (servings/day) }\end{array}$ \\
\hline Education (years) & $\begin{array}{l}1.000 \\
(1.545)\end{array}$ \\
\hline Education $^{2}$ & $\begin{array}{l}-0.0523 \\
(0.0807)\end{array}$ \\
\hline Education of the mother & \\
\hline None & $\begin{array}{l}-1.693 \\
(2.540)\end{array}$ \\
\hline Primary School & $\begin{array}{l}-0.788 \\
(2.090)\end{array}$ \\
\hline Secondary School & $\begin{array}{l}-1.862 \\
(2.226)\end{array}$ \\
\hline Sex (Male=1) & $\begin{array}{c}0.104 \\
(0.806)\end{array}$ \\
\hline Age & $\begin{array}{c}1.105 \\
(1.733)\end{array}$ \\
\hline $\mathrm{Age}^{2}$ & $\begin{array}{l}-0.0123 \\
(0.0192)\end{array}$ \\
\hline $\begin{array}{l}\text { Social Security } \\
\text { Base }=\text { Contributive }\end{array}$ & \\
\hline Subsidized Regime & $\begin{array}{l}-0.337 \\
(0.287)\end{array}$ \\
\hline Special Regime & $\begin{array}{c}0.175 \\
(0.383)\end{array}$ \\
\hline Not Affiliated & $\begin{array}{l}-0.385 \\
(0.304)\end{array}$ \\
\hline $\begin{array}{l}\text { Occupation } \\
\text { Base }=\text { Employed }\end{array}$ & \\
\hline Unemployed & $\begin{array}{l}-0.878 \\
(0.573)\end{array}$ \\
\hline Inactive & $\begin{array}{l}0.0469 \\
(0.157)\end{array}$ \\
\hline Owns Refrigerator & $\begin{array}{l}0.588^{* * *} \\
(0.264)\end{array}$ \\
\hline Constant & $\begin{array}{l}-21.10 \\
(35.69)\end{array}$ \\
\hline $\begin{array}{l}\text { Observations } \\
\text { R-squared }\end{array}$ & $\begin{array}{l}1,715 \\
0.120 \\
\end{array}$ \\
\hline
\end{tabular}

Output 18 2SLS Results on the Consumption Variable Including Wealth Score-One and Several Instruments

\begin{tabular}{|c|c|c|c|c|}
\hline \multirow{2}{*}{$\frac{\text { VARIABLES }}{\text { Education (years) }}$} & \multicolumn{4}{|c|}{ Fruits and Veqetables (servings/day) } \\
\hline & $\begin{array}{l}0.0315 \\
(0.126)\end{array}$ & $\begin{array}{l}0.0245 \\
(0.138)\end{array}$ & $\begin{array}{c}0.533 \\
(1.336)\end{array}$ & $\begin{array}{r}0.940 \\
(1.557)\end{array}$ \\
\hline Education $^{2}$ & & & $\begin{array}{l}-0.0275 \\
(0.0707)\end{array}$ & $\begin{array}{l}-0.0485 \\
(0.0813)\end{array}$ \\
\hline Exposition Dummy & $\begin{array}{l}-0.463 \\
(0.688)\end{array}$ & $\begin{array}{l}-0.411 \\
(0.693)\end{array}$ & & \\
\hline \multicolumn{5}{|c|}{ Education of the mother } \\
\hline None & & & $\begin{array}{l}-1.156 \\
(2.124)\end{array}$ & $\begin{array}{l}-1.220 \\
(2.299)\end{array}$ \\
\hline Primary School & & & $\begin{array}{l}-0.689 \\
(1.799)\end{array}$ & $\begin{array}{l}-0.530 \\
(1.926)\end{array}$ \\
\hline Secondary School & & & $\begin{array}{l}-1.238 \\
(2.018)\end{array}$ & $\begin{array}{l}-1.630 \\
(2.210)\end{array}$ \\
\hline Wealth Score & $\begin{array}{l}0.502^{* *} \\
(0.220)\end{array}$ & $\begin{array}{c}0.406^{* *} \\
(0.181)\end{array}$ & $\begin{array}{l}0.494^{* *} \\
(0.213)\end{array}$ & $\begin{array}{l}0.369^{*} \\
(0.199)\end{array}$ \\
\hline Sex $($ Male $=1)$ & $\begin{array}{l}-0.0184 \\
(0.242)\end{array}$ & $\begin{array}{c}-0.00317 \\
(0.262)\end{array}$ & $\begin{array}{l}0.0284 \\
(0.617)\end{array}$ & $\begin{array}{l}-0.0302 \\
(0.725)\end{array}$ \\
\hline Age & $\begin{array}{c}0.180 \\
(0.737)\end{array}$ & $\begin{array}{l}0.103 \\
(0.715)\end{array}$ & $\begin{array}{c}0.724 \\
(1.564)\end{array}$ & $\begin{array}{c}1.012 \\
(1.742)\end{array}$ \\
\hline $\mathrm{Age}^{2}$ & $\begin{array}{l}-0.00228 \\
(0.00829)\end{array}$ & $\begin{array}{l}-0.00141 \\
(0.00804)\end{array}$ & $\begin{array}{l}-0.00826 \\
(0.0173)\end{array}$ & $\begin{array}{l}-0.0114 \\
(0.0193)\end{array}$ \\
\hline \multicolumn{4}{|l|}{ Social Security } & \\
\hline \multicolumn{3}{|l|}{ Subsidized Regime } & & $\begin{array}{l}-0.245 \\
(0.245)\end{array}$ \\
\hline Special Regime & & $\begin{array}{l}0.0439 \\
(0.322)\end{array}$ & & $\begin{array}{l}0.135 \\
(0.376)\end{array}$ \\
\hline Not Affiliated & & $\begin{array}{l}-0.319 \\
(0.241)\end{array}$ & & $\begin{array}{l}-0.368 \\
(0.295)\end{array}$ \\
\hline \multicolumn{5}{|l|}{$\begin{array}{l}\text { Occupation } \\
\text { Base }=\text { Employed }\end{array}$} \\
\hline Unemployed & $\begin{array}{l}-0.671^{*} \\
(0.358)\end{array}$ & $\begin{array}{l}-0.630^{*} \\
(0.355)\end{array}$ & $\begin{array}{l}-0.809 \\
(0.503)\end{array}$ & $\begin{array}{l}-0.882 \\
(0.568)\end{array}$ \\
\hline Inactive & $\begin{array}{l}0.0857 \\
(0.126)\end{array}$ & $\begin{array}{c}0.120 \\
(0.124)\end{array}$ & $\begin{array}{l}0.0476 \\
(0.149)\end{array}$ & $\begin{array}{l}0.0583 \\
(0.158)\end{array}$ \\
\hline Owns Refrigerator & & $\begin{array}{l}0.370^{*} \\
(0.200)\end{array}$ & & $\begin{array}{l}0.362^{*} \\
(0.205)\end{array}$ \\
\hline Constant & $\begin{array}{l}-1.033 \\
(12.93) \\
\end{array}$ & $\begin{array}{c}0.222 \\
(12.62) \\
\end{array}$ & $\begin{array}{l}-12.45 \\
(31.81) \\
\end{array}$ & $\begin{array}{l}-19.40 \\
(35.98) \\
\end{array}$ \\
\hline Observations & 1,720 & 1,715 & 1,720 & 1,715 \\
\hline R-squared & 0.259 & 0.265 & 0.219 & 0.148 \\
\hline
\end{tabular}


Output 19 2SLS Results on the Consumption Variable- Ologit First Stage

\begin{tabular}{|c|c|c|}
\hline \multirow{2}{*}{$\frac{\text { VARIABLES }}{\text { Education (years) }}$} & \multicolumn{2}{|c|}{ Fruits and Vegetables (Servings/day) } \\
\hline & $\begin{array}{l}0.123^{* * *} \\
(0.0262)\end{array}$ & $\begin{array}{l}0.108^{* * * *} \\
(0.0281)\end{array}$ \\
\hline Wealth Score & & $\begin{array}{c}0.311^{* * *} \\
(0.109)\end{array}$ \\
\hline Sex $($ Male $=1)$ & $\begin{array}{l}-0.0917 \\
(0.193)\end{array}$ & $\begin{array}{l}-0.120 \\
(0.190)\end{array}$ \\
\hline Age & $\begin{array}{l}-0.0389 \\
(0.697)\end{array}$ & $\begin{array}{l}-0.0213 \\
(0.693)\end{array}$ \\
\hline $\mathrm{Age}^{2}$ & $\begin{array}{l}0.000302 \\
(0.00779)\end{array}$ & $\begin{array}{l}6.03 \mathrm{e}-05 \\
(0.00775)\end{array}$ \\
\hline $\begin{array}{l}\text { Social Security } \\
\text { Base }=\text { Contributive }\end{array}$ & & \\
\hline Subsidized Regime & $\begin{array}{l}-0.154 \\
(0.153)\end{array}$ & $\begin{array}{l}-0.107 \\
(0.148)\end{array}$ \\
\hline Special Regime & $\begin{array}{l}-0.0322 \\
(0.303)\end{array}$ & $\begin{array}{l}-0.0415 \\
(0.302)\end{array}$ \\
\hline Not Affiliated & $\begin{array}{l}-0.235 \\
(0.220)\end{array}$ & $\begin{array}{l}-0.248 \\
(0.218)\end{array}$ \\
\hline $\begin{array}{l}\text { Occupation } \\
\text { Base }=\text { Employed }\end{array}$ & & \\
\hline Unemployed & $\begin{array}{l}-0.624^{*} \\
(0.359)\end{array}$ & $\begin{array}{l}-0.630^{*} \\
(0.361)\end{array}$ \\
\hline Inactive & $\begin{array}{c}0.119 \\
(0.126)\end{array}$ & $\begin{array}{c}0.126 \\
(0.125)\end{array}$ \\
\hline Owns Refrigerator & $\begin{array}{c}0.481^{* * *} \\
(0.164)\end{array}$ & $\begin{array}{l}0.308^{*} \\
(0.168)\end{array}$ \\
\hline Constant & $\begin{array}{c}1.455 \\
(12.68) \\
\end{array}$ & $\begin{array}{c}1.294 \\
(12.60) \\
\end{array}$ \\
\hline Observations & 1,715 & 1,715 \\
\hline R-squared & 0.241 & 0.251 \\
\hline
\end{tabular}

Output 20 First stage on Education- One Instrument (left) and Several Instruments (right)

\begin{tabular}{lc}
\hline & \\
VARIABLES & Education (years) \\
\hline Interacted Dummy & $1.836^{* * *}$ \\
& $(0.327)$ \\
Exposition Dummy & $-6.520^{* * *}$ \\
& $(0.296)$ \\
Sex (Male=1) & $1.699^{* * *}$ \\
& $(0.351)$ \\
Age & 0.866 \\
& $(0.893)$ \\
Age ${ }^{2}$ & -0.0101 \\
& $(0.0100)$ \\
Social Security & \\
Base $=$ Contributive & \\
Subsidized Regime & $-1.889^{* * *}$ \\
& $(0.203)$ \\
Special Regime & $0.889^{* *}$ \\
& $(0.381)$ \\
Not Affiliated & $-1.147^{* * *}$ \\
& $(0.314)$ \\
Occupation & \\
Base $=$ Employed & \\
Unemployed & 0.283 \\
& $(0.439)$ \\
Inactive & -0.0809 \\
& $(0.167)$ \\
Owns Refrigerator & $1.587^{* * *}$ \\
& $(0.249)$ \\
Constant & -1.995 \\
& $(16.24)$ \\
\hline Observations & 2,032 \\
R-squared & 0.657 \\
\hline \multicolumn{1}{c}{ Robust standard errors in parentheses } \\
$* * * *$ p $<0.01, * *$ p $<0.05, * p<0.1$ \\
& \\
&
\end{tabular}

\begin{tabular}{|c|c|c|}
\hline VARIABLES & Education (years) & Education $^{2}$ \\
\hline Interacted Dummy 1 & $\begin{array}{l}2.788^{*} \\
(1.498)\end{array}$ & $\begin{array}{l}35.42 \\
(25.73)\end{array}$ \\
\hline Interacted Dummy 2 & $\begin{array}{c}1.147 * * * \\
(0.360)\end{array}$ & $\begin{array}{l}20.48 * * \\
(8.160)\end{array}$ \\
\hline Interacted Dummy 3 & $\begin{array}{l}1.226^{* * *} \\
(0.311)\end{array}$ & $\begin{array}{c}25.01 * * * \\
(7.522)\end{array}$ \\
\hline $\begin{array}{l}\text { Exposition of the moth } \\
\text { None }\end{array}$ & $\begin{array}{c}-11.97 * * * \\
(0.846)\end{array}$ & $\begin{array}{c}-220.8^{* * *} \\
(16.39)\end{array}$ \\
\hline Primary School & $\begin{array}{l}-9.506^{* * *} \\
(0.294)\end{array}$ & $\begin{array}{c}-182.6^{* * *} \\
(6.901)\end{array}$ \\
\hline Secondary School & $\begin{array}{l}-5.231 * * * \\
(0.277)\end{array}$ & $\begin{array}{l}-124.6^{* * *} \\
(6.607)\end{array}$ \\
\hline Sex(Male=1) & $\begin{array}{c}3.274^{* * *} \\
(0.368)\end{array}$ & $\begin{array}{c}61.86^{* * *} \\
(7.215)\end{array}$ \\
\hline Age & $\begin{array}{c}0.559 \\
(0.788)\end{array}$ & $\begin{array}{l}31.53 * \\
(17.48)\end{array}$ \\
\hline $\mathrm{Age}^{2}$ & $\begin{array}{r}-0.00627 \\
(0.00885)\end{array}$ & $\begin{array}{l}-0.351^{*} \\
(0.196)\end{array}$ \\
\hline $\begin{array}{l}\text { Social Security } \\
\text { Base }=\text { Contributive }\end{array}$ & & \\
\hline Subsidized Regime & $\begin{array}{c}-1.116^{* * *} \\
(0.153)\end{array}$ & $\begin{array}{c}-20.33^{* * *} \\
(2.826)\end{array}$ \\
\hline Special Regime & $\begin{array}{c}0.583 \\
(0.386\end{array}$ & $\begin{array}{l}14.76 \\
(9.110)\end{array}$ \\
\hline Not Affiliated & $\begin{array}{l}-0.776^{* * *} \\
(0.269)\end{array}$ & $\begin{array}{c}-15.69^{* * * *} \\
(5.111)\end{array}$ \\
\hline $\begin{array}{l}\text { Occupation } \\
\text { Base }=\text { Employed }\end{array}$ & & \\
\hline Unemployed & $\begin{array}{l}0.598^{*} \\
(0.342)\end{array}$ & $\begin{array}{l}6.478 \\
(7.754)\end{array}$ \\
\hline Inactive & $\begin{array}{l}0.0557 \\
(0.126)\end{array}$ & $\begin{array}{c}0.121 \\
(2.564)\end{array}$ \\
\hline Owns Refrigerator & $\begin{array}{l}0.847^{* * *} \\
(0.167)\end{array}$ & $\begin{array}{c}15.84^{* * *} \\
(3.122)\end{array}$ \\
\hline Constant & $\begin{array}{c}3.478 \\
(14.33)\end{array}$ & $\begin{array}{l}-378.4 \\
(317.5)\end{array}$ \\
\hline Observations & 2,032 & 2,032 \\
\hline R-squared & 0.789 & 0.772 \\
\hline
\end{tabular}


Output 21 First Stage on Education Including Wealth Score- One Instrument

\begin{tabular}{|c|c|c|}
\hline \multirow{2}{*}{$\frac{\text { VARIABLES }}{\text { Interacted Dummy }}$} & \multicolumn{2}{|c|}{ Education (years) } \\
\hline & $\begin{array}{c}2.107^{* * *} \\
(0.333)\end{array}$ & $\begin{array}{c}1.900^{* * * *} \\
(0.322)\end{array}$ \\
\hline Exposition Dummy & $\begin{array}{c}-6.961^{* * * *} \\
(0.293)\end{array}$ & $\begin{array}{c}-6.283^{* * * *} \\
(0.293)\end{array}$ \\
\hline Wealth Score & $\begin{array}{c}1.540^{* * *} \\
(0.136)\end{array}$ & $\begin{array}{c}1.038^{* * *} \\
(0.146)\end{array}$ \\
\hline $\operatorname{Sex}($ Male $=1)$ & $\begin{array}{c}1.382^{* * *} \\
(0.360)\end{array}$ & $\begin{array}{c}1.501^{* * *} \\
(0.344)\end{array}$ \\
\hline Age & $\begin{array}{c}1.170 \\
(0.892)\end{array}$ & $\begin{array}{c}0.683 \\
(0.884)\end{array}$ \\
\hline $\mathrm{Age}^{2}$ & $\begin{array}{l}-0.0136 \\
(0.0100)\end{array}$ & $\begin{array}{l}-0.00814 \\
(0.00991)\end{array}$ \\
\hline $\begin{array}{l}\text { Social Security } \\
\text { Base }=\text { Contributive }\end{array}$ & & \\
\hline Subsidized Regime & & $\begin{array}{c}-1.651^{* * *} \\
(0.203)\end{array}$ \\
\hline Special Regime & & $\begin{array}{l}0.875^{* *} \\
(0.375)\end{array}$ \\
\hline Not Affiliated & & $\begin{array}{c}-1.086^{* * *} \\
(0.305)\end{array}$ \\
\hline $\begin{array}{l}\text { Occupation } \\
\text { Base }=\text { Employed }\end{array}$ & & \\
\hline Unemployed & $\begin{array}{l}-0.0297 \\
(0.431)\end{array}$ & $\begin{array}{c}0.228 \\
(0.421)\end{array}$ \\
\hline Inactive & $\begin{array}{l}-0.193 \\
(0.171)\end{array}$ & $\begin{array}{c}-0.0309 \\
(0.164)\end{array}$ \\
\hline Owns Refrigerator & & $\begin{array}{c}0.956 * * * \\
(0.259)\end{array}$ \\
\hline Constant & $\begin{array}{l}-7.312 \\
(16.21)\end{array}$ & $\begin{array}{c}1.244 \\
(16.08)\end{array}$ \\
\hline Observations & 2,039 & 2,032 \\
\hline R-squared & 0.641 & 0.671 \\
\hline
\end{tabular}

Output 22 First Stage on Education Including Wealth Score-Several Instruments

\begin{tabular}{|c|c|c|c|c|}
\hline VARIABLES & Education (years) & Education $^{2}$ & Education (years) & Education $^{2}$ \\
\hline Interacted Dummy 1 & $\begin{array}{l}3.356^{* * *} \\
(1.354)\end{array}$ & $\begin{array}{l}47.14^{* *} \\
(23.35)\end{array}$ & $\begin{array}{l}2.807^{* *} \\
(1.431)\end{array}$ & $\begin{array}{c}35.76 \\
(25.04)\end{array}$ \\
\hline Interacted Dummy 2 & $\begin{array}{c}1.331 * * * \\
(0.372)\end{array}$ & $\begin{array}{c}23.78^{* * *} \\
(8.239)\end{array}$ & $\begin{array}{c}1.220^{* * * *} \\
(0.359)\end{array}$ & $\begin{array}{c}21.78^{* * *} \\
(8.129)\end{array}$ \\
\hline Interacted Dummy 3 & $\begin{array}{c}1.357^{* * *} \\
(0.316)\end{array}$ & $\begin{array}{c}27.53^{* * * *} \\
(7.575)\end{array}$ & $\begin{array}{c}1.264^{* * *} \\
(0.308)\end{array}$ & $\begin{array}{c}25.69 * * * \\
(7.466)\end{array}$ \\
\hline \multicolumn{5}{|l|}{$\begin{array}{l}\text { Exposition of the } \\
\text { mother }\end{array}$} \\
\hline None & $\begin{array}{c}-12.14^{* * *} \\
(0.774)\end{array}$ & $\begin{array}{c}-226.2^{* * *} \\
(15.15)\end{array}$ & $\begin{array}{c}-11.49 * * * \\
(0.853)\end{array}$ & $\begin{array}{c}-212.2^{* * *} \\
(16.85)\end{array}$ \\
\hline Primary School & $\begin{array}{c}-9.919 * * * \\
(0.287)\end{array}$ & $\begin{array}{c}-190.8^{* * * *} \\
(6.711)\end{array}$ & $\begin{array}{c}-9.316^{* * * *} \\
(0.293)\end{array}$ & $\begin{array}{c}-179.2^{* * * *} \\
(6.885)\end{array}$ \\
\hline Secondary School & $\begin{array}{c}-5.464^{* * *} \\
(0.277)\end{array}$ & $\begin{array}{c}-129.4^{* * * *} \\
(6.589)\end{array}$ & $\begin{array}{c}-5.121^{* * * *} \\
(0.275)\end{array}$ & $\begin{array}{c}-122.6^{* * *} \\
(6.561)\end{array}$ \\
\hline Wealth Score & $\begin{array}{c}0.840^{* * * 8} \\
(0.111)\end{array}$ & $\begin{array}{c}15.24^{* * *} \\
(2.009)\end{array}$ & $\begin{array}{c}0.577^{* * * *} \\
(0.109)\end{array}$ & $\begin{array}{c}10.30^{* * *} \\
(2.000)\end{array}$ \\
\hline $\operatorname{Sex}($ Male $=1)$ & $\begin{array}{c}3.069^{* * *} \\
(0.393)\end{array}$ & $\begin{array}{c}58.68^{* * *} \\
(7.277)\end{array}$ & $\begin{array}{c}3.103^{* 8 *} \\
(0.368)\end{array}$ & $\begin{array}{c}58.80^{* * *} \\
(7.207)\end{array}$ \\
\hline Age & $\begin{array}{c}0.756 \\
(0.793)\end{array}$ & $\begin{array}{l}35.22 * * \\
(17.72)\end{array}$ & $\begin{array}{c}0.468 \\
(0.784)\end{array}$ & $\begin{array}{l}29.90^{*} \\
(17.50)\end{array}$ \\
\hline $\mathrm{Age}^{2}$ & $\begin{array}{l}-0.00856 \\
(0.00889)\end{array}$ & $\begin{array}{c}-0.394^{* *} \\
(0.199)\end{array}$ & $\begin{array}{l}-0.00534 \\
(0.00880)\end{array}$ & $\begin{array}{l}-0.334^{*} \\
(0.197)\end{array}$ \\
\hline \multicolumn{5}{|l|}{$\begin{array}{l}\text { Social Security } \\
\text { Base=Contributive }\end{array}$} \\
\hline Subsidized Regime & & & $\begin{array}{c}-1.000^{* * * *} \\
(0.152)\end{array}$ & $\begin{array}{c}-18.26^{* * *} \\
(2.807)\end{array}$ \\
\hline Special Regime & & & $\begin{array}{l}0.586 \\
(0.384)\end{array}$ & $\begin{array}{l}14.81 \\
(9.030)\end{array}$ \\
\hline Not Affiliated & & & $\begin{array}{c}-0.747^{* * * *} \\
(0.266)\end{array}$ & $\begin{array}{c}-15.18^{* * *} \\
(5.065)\end{array}$ \\
\hline \multicolumn{5}{|l|}{ Occupation } \\
\hline Unemployed & $\begin{array}{c}0.436 \\
(0.348)\end{array}$ & & $\begin{array}{l}0.560^{*} \\
(0.340)\end{array}$ & $\begin{array}{c}5.804 \\
(7.775)\end{array}$ \\
\hline Inactive & $\begin{array}{c}-0.00306 \\
(0.129)\end{array}$ & & $\begin{array}{l}0.0802 \\
(0.126)\end{array}$ & $\begin{array}{c}0.557 \\
(2.564)\end{array}$ \\
\hline Owns Refrigerator & & & $\begin{array}{c}0.522^{* * *} \\
(0.175)\end{array}$ & $\begin{array}{c}10.05^{* * *} \\
(3.290)\end{array}$ \\
\hline Constant & $\begin{array}{r}-0.0117 \\
(14.40)\end{array}$ & $\begin{array}{l}-443.7 \\
(321.5)\end{array}$ & $\begin{array}{c}5.100 \\
(14.27) \\
\end{array}$ & $\begin{array}{l}-349.5 \\
(318.0) \\
\end{array}$ \\
\hline Observations & 2,039 & 2,040 & 2,032 & 2,032 \\
\hline R-squared & 0.782 & 0.765 & 0.794 & 0.775 \\
\hline
\end{tabular}


Output 23 Ologit First Stage on Education- One Instrument

\begin{tabular}{|c|c|c|c|c|}
\hline \multirow{2}{*}{$\begin{array}{l}\text { VARIABLES } \\
\text { Interacted Dummy }\end{array}$} & \multicolumn{4}{|c|}{ Education (years) } \\
\hline & $\begin{array}{c}1.334^{* * *} \\
(0.289)\end{array}$ & $\begin{array}{c}1.431^{* * *} \\
(0.289)\end{array}$ & & \\
\hline Exposition Dummy & $\begin{array}{c}-6.533 * * * \\
(0.335)\end{array}$ & $\begin{array}{c}-6.483^{* * *} \\
(0.336)\end{array}$ & & \\
\hline Education (ologit fitted values) & & & $\begin{array}{l}0.934^{* * *} \\
(0.0305)\end{array}$ & $\begin{array}{l}0.883 * * * \\
(0.0307)\end{array}$ \\
\hline Wealth Score & & $\begin{array}{c}0.797 * * * \\
(0.110)\end{array}$ & & $\begin{array}{c}1.024 * * * \\
(0.146)\end{array}$ \\
\hline Sex $($ Male $=1)$ & $\begin{array}{c}1.843^{* * *} \\
(0.379)\end{array}$ & $\begin{array}{c}1.706^{* * *} \\
(0.371)\end{array}$ & $\begin{array}{l}0.00233 \\
(0.346)\end{array}$ & $\begin{array}{l}-0.0956 \\
(0.336)\end{array}$ \\
\hline Age & $\begin{array}{c}1.517^{* *} \\
(0.742)\end{array}$ & $\begin{array}{l}1.364^{*} \\
(0.776)\end{array}$ & $\begin{array}{l}-0.468 \\
(0.896)\end{array}$ & $\begin{array}{r}-0.554 \\
(0.885)\end{array}$ \\
\hline $\mathrm{Age}^{2}$ & $\begin{array}{l}-0.0171^{* *} \\
(0.00832)\end{array}$ & $\begin{array}{l}-0.0155^{*} \\
(0.00870)\end{array}$ & $\begin{array}{l}0.00480 \\
(0.0100)\end{array}$ & $\begin{array}{c}0.00562 \\
(0.00992)\end{array}$ \\
\hline $\begin{array}{l}\text { Social Security } \\
\text { Base }=\text { Contributive }\end{array}$ & & & & \\
\hline Subsidized Regime & $\begin{array}{c}-1.331^{* * *} \\
(0.139)\end{array}$ & $\begin{array}{c}-1.174^{* * *} \\
(0.143)\end{array}$ & $\begin{array}{c}-0.640^{* * *} \\
(0.217)\end{array}$ & $\begin{array}{c}-0.469^{* *} \\
(0.216)\end{array}$ \\
\hline Special Regime & $\begin{array}{l}1.004 * * \\
(0.418)\end{array}$ & $\begin{array}{l}1.016 * * \\
(0.405)\end{array}$ & $\begin{array}{l}-0.0201 \\
(0.380)\end{array}$ & $\begin{array}{l}0.0227 \\
(0.376)\end{array}$ \\
\hline Not Affiliated & $\begin{array}{c}-0.843^{* * *} \\
(0.231)\end{array}$ & $\begin{array}{c}-0.781^{* * *} \\
(0.233)\end{array}$ & $\begin{array}{l}-0.356 \\
(0.319)\end{array}$ & $\begin{array}{l}-0.338 \\
(0.309)\end{array}$ \\
\hline $\begin{array}{l}\text { Occupation } \\
\text { Base }=\text { Employed }\end{array}$ & & & & \\
\hline Unemployed & $\begin{array}{l}0.0112 \\
(0.328)\end{array}$ & $\begin{array}{l}-0.0451 \\
(0.316)\end{array}$ & $\begin{array}{c}0.240 \\
(0.440)\end{array}$ & $\begin{array}{c}0.180 \\
(0.422)\end{array}$ \\
\hline Inactive & $\begin{array}{l}-0.103 \\
(0.123)\end{array}$ & $\begin{array}{l}-0.0718 \\
(0.125)\end{array}$ & $\begin{array}{l}0.00249 \\
(0.167)\end{array}$ & $\begin{array}{l}0.0438 \\
(0.164)\end{array}$ \\
\hline Owns Refrigerator & $\begin{array}{c}1.051^{* * *} \\
(0.175)\end{array}$ & $\begin{array}{c}0.637^{* * *} \\
(0.181)\end{array}$ & $\begin{array}{l}0.607^{* *} \\
(0.254)\end{array}$ & $\begin{array}{l}0.0370 \\
(0.261)\end{array}$ \\
\hline Constant & & & $\begin{array}{l}-3.475 \\
(16.33)\end{array}$ & $\begin{array}{r}-0.552 \\
(16.18)\end{array}$ \\
\hline $\begin{array}{l}\text { Observations } \\
\text { R-squared }\end{array}$ & 2,032 & 2,032 & $\begin{array}{l}2,032 \\
0.656\end{array}$ & $\begin{array}{l}2,032 \\
0.670 \\
\end{array}$ \\
\hline
\end{tabular}

Output 24 Short Regression- One Instrument (left) and Several Instruments (right)

\begin{tabular}{|c|c|}
\hline VARIABLES & $\begin{array}{c}\text { Fruits and Vegetables } \\
\text { (servings/day) }\end{array}$ \\
\hline Interacted Dummy & $\begin{array}{l}0.0306 \\
(0.283)\end{array}$ \\
\hline Exposition Dummy & $\begin{array}{c}-0.664^{* * * *} \\
(0.248)\end{array}$ \\
\hline Sex $($ Male $=1)$ & $\begin{array}{c}0.110 \\
(0.205)\end{array}$ \\
\hline Age & $\begin{array}{l}0.0766 \\
(0.751)\end{array}$ \\
\hline $\mathrm{Age}^{2}$ & $\begin{array}{l}-0.00108 \\
(0.00840)\end{array}$ \\
\hline $\begin{array}{l}\text { Social Security } \\
\text { Base }=\text { Contributive }\end{array}$ & \\
\hline Subsidized Regime & $\begin{array}{c}-0.375^{* * *} \\
(0.141)\end{array}$ \\
\hline Special Regime & $\begin{array}{l}0.0713 \\
(0.322)\end{array}$ \\
\hline Not Affiliated & $\begin{array}{l}-0.373^{*} \\
(0.223)\end{array}$ \\
\hline $\begin{array}{l}\text { Occupation } \\
\text { Base }=\text { Employed }\end{array}$ & \\
\hline Unemployed & $\begin{array}{l}-0.611 \\
(0.379)\end{array}$ \\
\hline Inactive & $\begin{array}{l}0.0876 \\
(0.132)\end{array}$ \\
\hline Owns Refrigerator & $\begin{array}{c}0.644^{* * *} \\
(0.167)\end{array}$ \\
\hline Constant & $\begin{array}{c}1.582 \\
(13.70)\end{array}$ \\
\hline Observations & 1,747 \\
\hline R-squared & 0.254 \\
\hline
\end{tabular}

\begin{tabular}{|c|c|}
\hline VARIABLES & $\begin{array}{c}\text { Fruits and Vegetables } \\
\text { (servings/day) }\end{array}$ \\
\hline Interacted Dummy 1 & $\begin{array}{l}-0.238 \\
(0.566)\end{array}$ \\
\hline Interacted Dummy 2 & $\begin{array}{c}0.210 \\
(0.337)\end{array}$ \\
\hline Interacted Dummy 3 & $\begin{array}{l}-0.0635 \\
(0.306)\end{array}$ \\
\hline Education of the moth & \\
\hline None & $\begin{array}{c}-1.189 * * * \\
(0.446)\end{array}$ \\
\hline Primary School & $\begin{array}{c}-0.809 * \cdots \\
(0.279)\end{array}$ \\
\hline Secondary School & $\begin{array}{c}-0.578^{* *} \\
(0.269)\end{array}$ \\
\hline Sex (Male=1) & $\begin{array}{c}0.183 \\
(0.208)\end{array}$ \\
\hline Age & $\begin{array}{l}0.0697 \\
(0.752)\end{array}$ \\
\hline $\mathrm{Age}^{2}$ & $\begin{array}{l}-0.000969 \\
(0.00841)\end{array}$ \\
\hline $\begin{array}{l}\text { Social Security } \\
\text { Base }=\text { Contributive }\end{array}$ & \\
\hline Subsidized Regime & $\begin{array}{c}-0.364^{* * *} \\
(0.141)\end{array}$ \\
\hline Special Regime & $\begin{array}{l}0.0502 \\
(0.324)\end{array}$ \\
\hline Not Affiliated & $\begin{array}{l}-0.383^{\circ} \\
(0.221)\end{array}$ \\
\hline $\begin{array}{l}\text { Occupation } \\
\text { Base }=\text { Employed }\end{array}$ & \\
\hline Unemployed & $\begin{array}{c}-0.613 \\
(0.380)\end{array}$ \\
\hline Inactive & $\begin{array}{c}0.104 \\
(0.133)\end{array}$ \\
\hline Owns Refrigerator & $\begin{array}{c}0.595 * * \\
(0.169)\end{array}$ \\
\hline Constant & $\begin{array}{c}1.717 \\
(13.71) \\
\end{array}$ \\
\hline $\begin{array}{l}\text { Observations } \\
\text { R-squared }\end{array}$ & $\begin{array}{l}1,747 \\
0.257\end{array}$ \\
\hline
\end{tabular}


Output 25 Short Regression Including Wealth Score- One Instrument and Several Instruments

\begin{tabular}{|c|c|c|c|c|}
\hline \multirow{2}{*}{$\begin{array}{l}\text { VARIABLES } \\
\text { Interacted Dummy }\end{array}$} & \multicolumn{4}{|c|}{ Fruits and Vegetables (servings/day) } \\
\hline & $\begin{array}{l}0.0585 \\
(0.281)\end{array}$ & $\begin{array}{l}0.0412 \\
(0.281)\end{array}$ & & \\
\hline Interacted Dummy 1 & & & $\begin{array}{l}-0.505 \\
(0.571)\end{array}$ & $\begin{array}{l}-0.329 \\
(0.571)\end{array}$ \\
\hline Interacted Dummy 2 & & & $\begin{array}{c}0.188 \\
(0.335)\end{array}$ & $\begin{array}{c}0.215 \\
(0.335)\end{array}$ \\
\hline Interacted Dummy 3 & & & $\begin{array}{c}-0.00965 \\
(0.305)\end{array}$ & $\begin{array}{r}-0.0389 \\
(0.304)\end{array}$ \\
\hline Exposition Dummy & $\begin{array}{c}-0.674^{* * *} \\
(0.240)\end{array}$ & $\begin{array}{l}-0.559 * * \\
(0.246)\end{array}$ & & \\
\hline $\begin{array}{l}\text { Education of the mother } \\
\text { None }\end{array}$ & & & $\begin{array}{l}-0.787 * \\
0.451\end{array}$ & $\begin{array}{l}-0.809^{*} \\
(0.456)\end{array}$ \\
\hline Primary School & & & $\begin{array}{c}-0.812^{* * * *} \\
(0.271)\end{array}$ & $\begin{array}{l}-0.664^{* *} \\
(0.279)\end{array}$ \\
\hline Secondary School & & & $\begin{array}{c}-0.609 * * \\
(0.261)\end{array}$ & $\begin{array}{l}-0.499^{*} \\
(0.266)\end{array}$ \\
\hline Wealth Score & $\begin{array}{l}0.544^{* * *} \\
(0.0887)\end{array}$ & $\begin{array}{c}0.431^{* * *} \\
(0.0975)\end{array}$ & $\begin{array}{l}0.513^{* * *} \\
(0.0932)\end{array}$ & $\begin{array}{l}0.409^{* * *} \\
(0.1000)\end{array}$ \\
\hline $\operatorname{Sex}($ Male $=1)$ & $\begin{array}{l}0.0249 \\
(0.204)\end{array}$ & $\begin{array}{l}0.0428 \\
(0.202)\end{array}$ & $\begin{array}{l}0.0960 \\
(0.207)\end{array}$ & $\begin{array}{l}0.0867 \\
(0.205)\end{array}$ \\
\hline Age & 0.172 & 0.0686 & 0.169 & 0.0673 \\
\hline $\mathrm{Age}^{2}$ & $\begin{array}{c}(0.757) \\
-0.00219 \\
(0.00847)\end{array}$ & $\begin{array}{c}(0.746) \\
-0.00103 \\
(0.00834)\end{array}$ & $\begin{array}{c}(0.759) \\
-0.00216 \\
(0.00850)\end{array}$ & $\begin{array}{c}(0.747) \\
-0.00101 \\
(0.00836\end{array}$ \\
\hline $\begin{array}{l}\text { Social Security } \\
\text { Base }=\text { Contributive }\end{array}$ & & & & \\
\hline Subsidized Regime & & $\begin{array}{l}-0.274 * 8 \\
(0.139)\end{array}$ & & $\begin{array}{c}-0.279 * * \\
(0.139)\end{array}$ \\
\hline Special Regime & & $\begin{array}{l}0.0291 \\
(0.323)\end{array}$ & & $\begin{array}{l}0.0192 \\
(0.325)\end{array}$ \\
\hline Not Affiliated & & $\begin{array}{l}-0.373^{*} \\
(0.221)\end{array}$ & & $\begin{array}{l}-0.383^{*} \\
(0.218)\end{array}$ \\
\hline $\begin{array}{l}\text { Occupation } \\
\text { Base }=\text { Employed }\end{array}$ & & & & \\
\hline Unemployed & $\begin{array}{l}-0.672^{*} \\
(0.385)\end{array}$ & $\begin{array}{l}-0.622 \\
(0.385)\end{array}$ & $\begin{array}{l}-0.671^{*} \\
(0.386)\end{array}$ & $\begin{array}{l}-0.631 \\
(0.384)\end{array}$ \\
\hline Inactive & $\begin{array}{l}0.0583 \\
(0.131)\end{array}$ & $\begin{array}{c}0.101 \\
(0.132)\end{array}$ & $\begin{array}{l}0.0711 \\
(0.131)\end{array}$ & $\begin{array}{c}0.112 \\
(0.132)\end{array}$ \\
\hline Owns Refrigerator & & $\begin{array}{l}0.361^{* *} \\
(0.179)\end{array}$ & & $\begin{array}{l}0.345^{*} \\
(0.179)\end{array}$ \\
\hline Constant & $\begin{array}{l}0.0321 \\
(13.78)\end{array}$ & $\begin{array}{c}1.695 \\
(13.59)\end{array}$ & $\begin{array}{l}0.0950 \\
(13.82)\end{array}$ & $\begin{array}{c}1.740 \\
(13.62)\end{array}$ \\
\hline Observations & $\frac{13.752}{1,752}$ & $\frac{(10.91)}{1,747}$ & 1,752 & 1,747 \\
\hline R-squared & 0.257 & 0.265 & 0.260 & 0.268 \\
\hline
\end{tabular}

Output 26 Short Regression with Ologit First Stage

\begin{tabular}{|c|c|c|}
\hline \multirow{2}{*}{$\begin{array}{l}\text { VARIABLES } \\
\text { Education (ologit fitted values) }\end{array}$} & \multicolumn{2}{|c|}{ Fruits and Vegetables (servings/day) } \\
\hline & $\begin{array}{l}0.115 * * * \\
(0.0262)\end{array}$ & $0.0966 * * *$ \\
\hline Wealth Score & & $\begin{array}{c}0.355^{* * * *} \\
(0.104)\end{array}$ \\
\hline Sex $($ Male=1) & $\begin{array}{l}-0.107 \\
(0.202)\end{array}$ & $\begin{array}{l}-0.127 \\
(0.199)\end{array}$ \\
\hline Age & $\begin{array}{l}-0.115 \\
(0.753)\end{array}$ & $\begin{array}{l}-0.0768 \\
(0.747)\end{array}$ \\
\hline $\mathrm{Age}^{2}$ & $\begin{array}{c}0.00110 \\
(0.00842)\end{array}$ & $\begin{array}{l}0.000637 \\
(0.00836)\end{array}$ \\
\hline $\begin{array}{l}\text { Social Security } \\
\text { Base }=\text { Contributive }\end{array}$ & & \\
\hline Subsidized Regime & $\begin{array}{l}-0.224 \\
(0.156)\end{array}$ & $\begin{array}{l}-0.162 \\
(0.152)\end{array}$ \\
\hline Special Regime & $\begin{array}{l}-0.0541 \\
(0.324)\end{array}$ & $\begin{array}{l}-0.0771 \\
(0.325)\end{array}$ \\
\hline Not Affiliated & $\begin{array}{l}-0.277 \\
(0.228)\end{array}$ & $\begin{array}{l}-0.298 \\
(0.225)\end{array}$ \\
\hline $\begin{array}{l}\text { Occupation } \\
\text { Base }=\text { Employed }\end{array}$ & & \\
\hline Unemployed & $\begin{array}{l}-0.605 \\
(0.378)\end{array}$ & $\begin{array}{l}-0.612 \\
(0.384)\end{array}$ \\
\hline Inactive & $\begin{array}{c}0.102 \\
(0.133)\end{array}$ & $\begin{array}{c}0.110 \\
(0.132)\end{array}$ \\
\hline Owns Refrigerator & $\begin{array}{c}0.523 * * * * \\
(0.173)\end{array}$ & $\begin{array}{l}0.299^{*} \\
(0.181)\end{array}$ \\
\hline Constant & $\begin{array}{c}1.824 \\
(13.71)\end{array}$ & $\begin{array}{c}1.881 \\
(13.60)\end{array}$ \\
\hline Observations & 1,747 & 1,747 \\
\hline R-squared & 0.254 & 0.265 \\
\hline
\end{tabular}

